\title{
The Burgher Religiosity
}

Bequests of last will reflected the nature of urban religiosity. The concepts of Purgatory and the judgment of the soul provided the immediate impetus for the rise of the so-called canonical will, which allowed a person lying on their deathbed to meaningfully influence the duration of their soul's suffering in Purgatory, or whether they would be damned eternally for their sins. The will was the perfect means for testators to use their wealth to secure a place in heaven and guarantee themselves eternal life. Viewed from this perspective, late-medieval urban religiosity was strongly influenced by the institution of the will, seen as a tool for ensuring one's salvation. Works of charity in urban areas, the creation and running of hospitals, the building of churches and parish chapels, clergy supported by pious foundations and altarages, aid to the poor and the infirm - all of these were financed in large part by pious bequests made by burghers in their wills.

The will has long been a symbol of mortality and a means of preparing for one's death. As such, it allows us to analyse the nature and forms of urban piety. The issue of urban religiosity is an extremely complicated one, and wills shed light on merely one key aspect of this topic. ${ }^{1}$ While wills contained private, individual dispositions to be carried out in the event of a person's death, in most cases, they drew upon a limited set of general conventions and forms of bequests made for opera pietatis. We might thus ask ourselves here whether it is necessary to look for originality, creativity and individuality in matters concerning religion, which derives its power from collective rituals, the doctrines of canon law, and long-standing, universally recognised customs. A follow-up question here would be: can such bequests tell us something about the testator and his or her social position, family history, personal experience and beliefs,

1 This seemingly straightforward term was defined well by Halina Manikowska: "The term "religiosity" is used by researchers commonly, but also quite loosely, interchangeably with others, such as forms of religious life, piety, forms of religious worship. It is used relatively precisely in socio-religious research, but this [definition] does not fully address the issues covered by this concept in historiography. It is understood as a set of religious practices characteristic of a given epoch and particular social groups, and above all, rituals, and, more rarely, internal attitudes, beliefs, knowledge, religious feelings, ideas related to spiritual reality referred to, especially in the last forty years, as the concept of a religious mentality.; eadem, Religïność miejska, in Ecclesia et civitas. Kościót i życie religïne w mieście średniowiecznym, ed. Halina Manikowska, Hanna Zaremska (Warszawa: Instytut Historii PAN, 2002), 12.

(C) JAKUB WYSMUŁEK, 2021 | DOI:10.1163/9789004461444_006

This is an open access chapter distributed under the terms of the CC BY-NC-ND 4.0 license. 
even though they usually followed established conventions? In short, can we see the person behind the testamentary bequest? ${ }^{2}$ Do the surviving wills of Krakow burghers tell us something about their real religious convictions, or are they just mindless reproductions of religious formulas propagated by the Church and the social elite? And finally, is the model of religiosity found in these wills truly representative of urban society or only that of a certain social group? We need to address these questions if we want to tackle the seemingly obvious question of whether wills can be used to evaluate the nature of urban religiosity in its various forms. ${ }^{3}$

In the late Middle Ages, piety had an important social dimension, reflected in both the rituals and devotional practices associated with the Church, which promoted a traditional conception of the nature and role of community and a mass model of religiosity. ${ }^{4}$ Community events filled with religious symbolism provided a break from the routine of burghers' everyday religious practices. Engaging in weighty academic discussions, ${ }^{5}$ expressing strong feelings during sermons by renowned itinerant preachers, ${ }^{6}$ planning pilgrimages to Rome

2 Aron Gurevich, despite his best efforts, remained skeptical about the possibility of seeing traces of individualism in this era: idem, The Origins of European Individualism (Oxford: Blackwell, 1995).

3 Martin Nodl very rightly pointed out the different conditions under which the will operated and the role it played in the cities of Central and Eastern Europe compared with those of Western Europe, particularly in the Apennine Peninsula. "However, since this increase [in the number of wills-J.W.] involves a very unrepresentative and clearly a minority group of the urban population, it is very difficult to extend the conclusions of the analysis of the preserved wills to the entire urban population and to base on them conclusions concerning the piety and religious practices of the urban community in the fifteenth century."; idem, "Středověký testament jako abnormalita," in Pozdně středověké testamenty v českých městech. Prameny, metodologie a formy využití. Sbornik př́spěvků z konference uspořádané zo. listopadu 2005 Archivem hlavního města Prahy a Historickým ústavem Akademie věd České republiky, ed. Kateřina Jišová, Eva Doležalová (Praha: Scriptorium, 2006), 158.

4 Jan Drabina, Wierzenia, religie, wspólnoty wyznaniowe w średniowiecznej Polsce ina Litwie i ich koegzystencja (Krakow: Nakł. Uniwersytetu Jagiellońskiego, 1994), 58-59.

5 For example, a stir brought about by the visit of Jerome of Prague, accused of heresy, to Krakówin 1413. During his stay in the city, he preached sermons 'causing considerable agitation among the Krakówclergy and burghers, although according to the Krakow bishop Wojciech Jastrzębiec, "common people in Poland are unable to understand the teachings of such a great philosopher."; Paweł Kras, Husyci w piętnastowiecznej Polsce (Lublin: Towarzystwo Naukowe Katolickiego Uniwersytetu Lubelskiego, 1998), 40-43.

6 John Kapistran's stay in Krakow from August 1453 to May 1454 was particularly significant. The impact of his sermons in the Krakow market was described in detail by Długosz; Joannis Dlugosssii, Annales seu Cronicae incliti Regni Poloniae, lib. XII, Cracoviae 2003, 171-172; cf. Jerzy Kłoczowski, Wspólnoty zakonne w średniowiecznej Polsce (Lublin: Wydawnictwo KUL, 2010), 261-265. 
during Jubilee years, ${ }^{7}$ and participating in holidays, processions and church fairs $^{8}$ were all part of life shared with the larger community. It appears that the emergence in the Kingdom of Poland during the analysed period of new trends promoting a more personal, spiritual approach to religion, referred to in the West (especially in the Netherlands) as devotio moderna,${ }^{9}$ had little impact on this state of affairs, with their appeal being limited primarily to social elites. In his timeless book, The Autumn of the Middle Ages, Johan Huizinga painted a suggestive picture of the religious attitudes and 'emotional standards' (using Peter Sterns concept ${ }^{10}$ ) that in his opinion distinguished 'modern' believers from 'traditional' ones, observing that:

[The] fifteenth century displays this strong religious emotion in a dual form. On the one side, it reveals itself in those vehement moments when an itinerant preacher periodically seizes a whole crowd with his words, igniting all that spiritual fuel like dry tinder. This is the spasmodic expression of that Christological emotion: passionate, intense, but highly transitory. The other aspect is shown by a few individuals who lead their sensitivity into a path of eternal quietude and normalize it into a new life form, that of introspectiveness. This is the pietistic circle of those who, fully conscious of being innovators, call themselves the Modern Devotees, that is contemporary people of piety.11

Halina Manikowska, Jerozolima - Rzym - Compostela, 6-8.

8 Aleksandra Witkowska, "Kształtowanie się tradycji pątniczych w średniowiecznym Krakowie," KH, vol. 86 (1979), 965-985.

9 "The general idea uniting all groups involved in the renewal of the spiritual life of the whole of societatis christianae was to return to the biblical (evangelical) and sacramental sources of faith in order to reduce the formality of the relationship between a person and God and to make it more individual and direct. This general aspiration consisted of a number of minor tendencies, mainly emphasizing the role of affection in one's spiritual life and its superiority over intellectual reflection (formulated mainly as part of the so-called schola affectus), emphasizing religious experience based on personal prayer and contemplation and promoting various forms of individual devotion. The increasing emotionality of the religious mentality of the late Middle Ages was particularly extreme in the phenomenon of dolorism, which is characteristic of mass piety, but also present in the devotion of elites, the origins of which can be found in the socio-economic and cultural circumstances of the fourteenth century"; Alicja Szulc, Homo religiosus późnego średniowiecza. Bernardyński model religïności masowej (Studia i Materiały - Uniwersytet im. Adama Mickiewicza w Poznaniu. Wydział Teologiczny, 10o) (Poznan: Uniwersytet im. Adama Mickiewicza, 2007), 45. tions and Emotional Standards," The American Historical Review 9o, no. 4 (1985), 813-83o.

11 Johan Huizinga, The Autumn of the Middle Ages, trans. Rodney Payton, Ulrich Mammitzsch (Chicago: University of Chicago Press, 1996), 221. 
It seems that, outside of Dutch and northern German cities, this phenomenon did not become a formalized movement or widespread among townspeople. In Central and Eastern Europe, the only example of such an institutionalized new form of religious life, one modelled on the Dutch Congregation of Windesheim, was found in the Hanseatic city of Chełmno. ${ }^{12}$

In Krakow, new forms of worship and devotional practices were largely inspired by the University of Krakow, ${ }^{13}$ and three new reformist religious communities: the Order of Canons Regular, a congregation of Czech provenance based at the parish church of Corpus Christi in Kazimierz (which was very popular among Krakow's burghers); the Order of Saint Paul the First Hermit, originally founded in Hungary and adhering both to ermetic and ascetic principles and the Rule of St. Augustine; and the Bernardines, whose first Polish monastery in Stradom (now a part of Krakow) was founded by Zbigniew Oleśnicki in the mid-fifteenth century. ${ }^{14}$

We can assume the religiosity of Krakow's burghers in the late Middle Ages was also shaped by the mosaic of other religious institutions that were founded in the city's environs during this period, and which embodied various religious beliefs and practices. Krakow was praised as a bustling religious centre by the bishop Stanisław Ciołek in his poem Laus Cracoviae, ${ }^{15}$ and we can assume that the city's wealth of religious institutions was also reflected in the testamentary bequests made there. As part of a complex, multi-layered social reality, urban religiosity assumed different forms depending on the testator's social status and cultural capital, as well as the nature of a given form of religious expression. Therefore, the differences in religious practices reflected to a large extent differences in the social position of particular burghers.

In the years 1472-1539, a home of the Brethren of the Common Life was brought from Zwolle by the bishop of Chełmno, Wincenty Kiełbasa.; cf. Alicja Szulc, Homo religiosus, 37; Zenon Hubert Nowak, Kultura umystowa Prus Królewskich w czasach Kopernika (Toruń: Państw. Wyd. Nauk., 1972), 24-25.

"Under the influence of the reformist views of Matthew of Krakow, a significant group of Krakow masters adopted the idea of the Prague version of devotio moderna, and expressed it in writings, disputes and sermons, understanding the new movement in the sphere of spirituality and religion as a kind of new theology. The leading representatives of this movement in Krakow circles weren Stanisław from Skalbmierz, Matthias from Łabiszyn, Benedict Hesse, John from Dąbrówka, and above all, the Cistercian (later Carthusian) Jacob from Paradyż, whose rich ascetic and mystical works bear clear signs of a new, deeper understanding of theology and spirituality, similar to the classical devotio moderna"; Alicja Szulc, Homo religiosus, 42. Stanisław Bylina, "Religijność mieszkańców Europy Środkowo-Wschodniej w późnym średniowieczu," in Cywilizacja europejska. Wyktady i eseje, ed. Maciej Koźmiński (Warszawa: Wydaw. Inst. Hist. PAN, 2005), 108.

15 Stanisław Ciołek, Pochwała Krakowa, in Najstarsza poezja polsko-łacińska (do połowy XVI wieku), ed. Marian Plezia (Wrocław: Ossolineum, 2005), 30-33. 


\section{A Personal Relationship with God}

\section{$1.1 \quad$ Clergy \\ 1.1.1 Confessors}

The most intimate aspect of Catholic religiosity is one's personal relationship with God, the Virgin Mary and the saints. The sacrament of Holy Confession, the growing practice of Eucharistic adoration, and the awakening of a need for personal communion with the sacred, brought people closer to God and increased the intensity of their religious experiences. Because this relationship was generally a personal and intimate one, we do not have many testimonies that would allow us to assess the significance and scale of this phenomenon of personal communion. It also seems that this type of direct, intimate relationship with God, marked by intense and mystical experiences, was the preserve of a small number of affluent and pious burghers. The prevalence of this type of experience must have also been influenced by the rise in literacy, which more generally brought about transformational changes in people's thinking. ${ }^{16}$

Since the Fourth Council of the Laterans in 1215, in accordance with Church teachings (later confirmed in the synod's statutes), the Catholic Church has obliged all Christians to have their confessions heard at least once a year, during the Easter season. ${ }^{17}$ The Church strongly emphasised the necessity of fulfilling this duty, seeing it as a important element of 'the cure of souls' (cura animarum) and a prerequisite for receiving Holy Communion. It tied this requirement to a call to heed the teachings of sermons, which were likened to the sowing of the fields, while the sacrament of confession was compared to the reaping of their fruits. ${ }^{18}$ Both in the West and in Poland, simple, mnemonic

16 " $[. .$.$] the construction and contemplation of the text constitutes a reflection on the reli-$ gious life, an invitation not simply to consolidate but to elaborate [...] the construction of the text, which is in any case something other than the transcription of discourse, can lead to its contemplation, to the development of thoughts about thoughts, to a metaphysic that may require its own metalanguage"; Jack Goody, The Logic of Writing and the Organisation of Society (Cambridge: Cambridge University Press, 1986), 37-38.

"The time of this confession was not specified more precisely, but the imposition of one confession per annum in one canon, with the obligation of Communion at Easter meant it happened during Lent, and in principle shortly before receiving the Eucharist.”; Izabela Skierska, Obowiazek mszalny w średniowiecznej Polsce (Warszawa: Wydawn. Instytutu Historii PAN, 2003), 240; cf. Stanisław Bylina, Spowiedź jako instrument katechezy $i$ nauki wspótżycia społecznego w Polsce późnego średniowiecza, in Spoteczeństwo Polski średniowiecznej, vol. 5, ed. Stefan.K. Kuczyński (Warszawa: Państw. Wydaw. Naukowe, 1992), 255-265. 
instructions were given on how to prepare for Confession: "A simple, humble confession is to be pure and faithful, frequent and honest, prudent and voluntary, modest, whole, secret, tearful, imminent, strong and obedient."19 This message was emphasised in many published sermons that both propagated the instructions of the Council's twenty-first canon (Omnis utriusque sexus) and advised believers to have their confessions heard as often as possible (though the question of how often was usually left to the individual, based on their personal needs). ${ }^{20}$

Disputes between parish clergy and mendicant orders about the right to administer the Sacrament of Penance demonstrate not only that Confession was a profitable undertaking, but also the significance of Confession as part of the pastoral care provided to parishioners. ${ }^{21}$ Having analysed modern sources on the ritual of confession, Jean Delumeau observed:

There is no doubt that the forgiveness expressed by God was a source of comfort and strength for the souls of those possessing a genuine religious and ethical sensitivity. Such people therefore turned to their confessor not because they were forced to do so by Church law but because they saw him as a 'guide of the conscience,' a trusted friend and confidant. In the seventeenth century, we can observe a new cultural phenomenon reflecting a deep psychological sensitivity, especially among the wealthy: people having a 'guide of the conscience' in whom they could entrust

kaznodziejskie w Polsce późnego średniowiecza. Sermones dominicales et festivales z tzw. kolekcji Piotra z Mitostawia (Kielce: Wydawnictwo Akademii Świetokrzyskiej, 2007), 383-384.

19 "Prosta, pocorna spowyedz ma bycz czysta ywyerna, Cząsta yodcrita, rostropna ydobrowolna, Sromyeslywa, czała, thayemnya, anaszą szalvyącza placzlywa rychla moczna abarszo poslussna," Krzysztof Bracha, Nauczanie kaznodziejskie, 384-385.

Such behavior was recommended by, among others, Nicholas from Błonie, who referred to a sinner as: "qui semper est in mora." There were only four cases in which one should confess: before receiving Holy Communion, in fear of death, pressed by one's conscience, and if one fears a priest will not be available again; cf. Krzysztof Bracha, Nauczanie kaznodziejskie, 387. Nicholas also recommended that believers receive communion at least three times a year: on Easter, Ascension Thursday and Christmas, which, however, does not seem to have been widely practiced; cf. Izabela Skierska, Obowiazek mszalny, 249 .

$21 \quad$ Pope Clement v sought to regulate this problem at the Council of Vienne of 1311 and 1312. The Mendicants could hear confessions and give communion to the faithful only with the special consent of the parson. They could, however, freely tend to people who lived in their homes and in their hospitals. However, later sources point to disputes and tensions concerning the issue.; Izabela Skierska, Obowiazek mszalny, 245-246; Alicja Szulc, Homo religiosus, $188-197$. 
their most intimate secrets and who helped their penitents navigate the difficult path to salvation. ${ }^{22}$

These observations also apply to the late Middle Ages, though such practices were limited to a circle of wealthy, pious Krakow burghers. The fact that the confessor was sometimes mentioned in the will alongside other people close to the testator may in itself testify to a deeper level of religious devotion, one not limited to the annual Easter Confession (and probably combined with the frequent taking of Holy Communion) ${ }^{23}$ In 1369 , upon embarking on a pilgrimage to Rome, Claire, widow of John Hobschbeck, left, among her other pious bequests, one grivna to her confessor Wiślicz. ${ }^{24}$ In 1439 , the court plenipotentiary Lawrence left his confessor Jacob Stegen six grivna and appointed him as one of the executors of his will, which seems to be evidence of a close bond existing between them..$^{25}$ Claire, the pious widow of Jacob Rolle, must have also had a close relationship with her confessor. ${ }^{26}$ In her 1419 will, she indicated that since her husband had not left a will, she would make pious bequests as a means of securing the salvation of both spouses' souls. ${ }^{27}$ In her bequest, made

22 Jean Delumeau, Wyznanie i przebaczenie. Historia spowiedzi, trans. Maryna Ochab (Gdańsk: Marabut, 1997), 109-110 (J. Delumeau, L'aveu et le pardon: Les difficultés de la confession, XIIIe-XVIIIe siècle, Fayard 2014).

"The eucharistic piety movement, which involved the postulate of frequent or even daily Communion by lay people, was quite nonconformist considering the general caution of the Church in this respect and the resulting practice of Easter Communion only... This practice, although it is unclear how widespread it became, was typical of big cities: with the exception of Prague in Wrocław and perhaps Krakow, where the postulates of lay people's frequent participation in the Eucharist met with rather timid echoes in the deliberations of university scholars"; Stanisław Bylina, Religijność mieszkańców Europy Środkowo-Wschodniej, 109-110.

"[...] unam marcam domino Wislicz suo confessori”; SCAB., no. 414.

"Item der sachin aus czu richten alze obin geschreben steet zo kyse ich mir den Erwirdigen prister her Jocob Stegen of dem hause unser beyder beichtvatir und dorczu ouch Stano Apteker Hannus den Bader of dem Zande und kyze ouch dorczu meyne eliche hawsfrawe den vir personen gebe ich macht der sachen ausczurichten alz is oben geschreben steet beyde geystlich und wertlich ydach zo sal under den vir personen eyne an dy ander nichtis tuen"; SCAB. 6, fol. 184.

26 The disposition in the event of Jacob Rolle's death was entered into the book of the bench court in 1392. However, it did not contain any pious bequests.; SCAB., no. 1425 .

"[...] atque dicti quondam eius mariti, qui decedens testamentum aliud non fecit, nisi quod ipsum disponendum eius fideli reliquit voluntati [...]. In quibus omnibus ac in alijs missis et oracionibus suis, quas consciencie eorum reliquit, offerant memoriam pro salute anime Iacobi Rolle, cuius duris laboribus ea bona sint acquisita, et anime eiusdem Clare, cuius liberali donacione sic eorum quieti et indigencie sit prouisum"; KDM K, vol. 3 , no. 406, 532-534 (1419). 
in the form of a notarial deed, Claire made generous pious bequests of 102 grivna and founded a perpetual altarage at a newly consecrated altar dedicated to Mary Magdalene in St. Mary's Church. ${ }^{28}$ The first prebendary was to be Claire's confessor Nicholas von Oyes. ${ }^{29}$

It was the confessor who usually took last confession and administered the sacrament of the anointing of the sick. They thus had a strong influence on the spirituality and religious practices of burghers, and on the manner in which they departed from the earthly world. The roles played by confessors and the bequests made to them indicate that they not only influenced the decision to make a will and how money for opera pietatis should be allocated, but were also later entrusted with caring for the soul of the deceased. In 1433, Margaret widow of the stallholder Jost, left most of her estate to her confessor Nicholas, the altarist of the Altar of St. Anna at St. Mary's Church. ${ }^{30}$ Similarly, in 1443, Catherine, widow of the glassmaker Cloze, left most of her estate to her confessor Nicholas Gertner. ${ }^{31}$ In 1438 , Gertner was referred to in the council book

28 "Preterea humiliter obtulit, legauit, dedit et commisit excellentissime celorum Regine, virgini Marie domum suam lapideam cum utensilibus et rebus relinquendis ad prebendam sacerdotalem perpetui altaris, post eius obitum in Ecclesia eiusdem gloriose virginis in Cracouia super altari iam consecrato beate Marie Magdalene comparandam et instituendam per eius executores"; KDMK, vol. 3, no. 406.

29 In a slightly modified version of this will, entered into the book of the bench court a year later, the testator confirmed the foundation of the altar and appointing of Nicholas, her confessor, as its altarist.: "Ich Clara Jacobs Rolle Witwe Widirruffe alle goben die ich vormols benunpt hatte noch meyne tode geben und mache meyn Testament und lecztin willen und zelgerete Alzo, czu erste bescheide ich meyn haus hindir den vlaschbanken do ich iczunt ynne wone und allis gut und gerete mit der gerade nichtis ausgenomen noch ausgeslossen gebe ich und bescheide noch meyme tode, das is Niclos Bastgert und Cuncze Zonnenborn dorin czinse kauffen ewikliche czu beleenunge eynis Altaris in Unsir Liben Frauwen pfarer kirchin ho czu Cracow und ich wil das denselben altir haben sal herre Niclos von Oyes meyn beychtfatir, den die herren Rathmannen der stat Cracow, deine Bischoffe antworten sullen In czu bestetigin czu dinsteben und obir derselben Altir, das her der irste Altir herre als Fare ap her lebit seyn und worden sal, den ich das loen desselben Altires gebe czu ewigen czeyten, auch noch desselbigen herren Niclos meynes beichtfatirs tode eyn andirn czu dirselbin altir deme Bischoffe czu antwortin in eyn zogetaner undirscheit und mosse das sie nymands noch des obgenanten fatir Niclos tode czu eynen Altirherre antwertin sullen deme Bischoffe wennen ey Capplan aus der obgenantes Unser Liben Frawen Pfarrkirchin"; SCAB. 5, fol. 31 (1420).

$30 \quad$ "Item allis das ich lossen werde boben dy gerade, das bescheyde ich meyme beichtvater hern Niclas, elthern das elters sinte Anne czu Unser Liben Frawen, mit befelunge meyner zele, als ich Im getrawe"; SCAB. 6, fol. 59 (1433).

$31 \quad$ "Item alle meyne obrige habe und dy neyge was do bleybet befele ich meynen beychtfater das her das alzo do hin weynde alzo ich im befolen habe mit meynen sele dorch meyner sele und der meyner und meynes selikeyt wille. Ich sunderlich bescheide ich meynem 
as the chaplain of the municipal council and the Polish preacher at St. Mary's Church. ${ }^{32}$ In both cases, the testators brief bequests asked their beneficiaries to pray for the salvation of their souls (befelunge meyner zele, meyner sele selikeit). Although testators' bequests naturally varied in terms of the amounts and types of assets bequeathed, in most cases confessors were given a bequest worth several grivna. ${ }^{33}$ Testators sometimes requested that specific actions be taken by confessors on behalf of their soul, such as saying thirty Gregorian Masses for the release of the soul (pro tricesima legenda) ${ }^{34}$ or donating money for opera pietatis in their name. ${ }^{35}$ Some burghers also left clothing to their confessors, which is certainly a sign that a strong bond existed between them. John Czenmark of Košice, husband of a Krakow burgher woman, left his black coat to his confessor Lucas. ${ }^{36}$ The patrician burgher John Sweidniczer left his confessor a blue robe $(\mathrm{rog}),{ }^{37}$ while Ursula, daughter of the late councillor George Szwarcz, bequeathed a fur coat (slymenen pelcz) to her confessor John Slepkogil. ${ }^{38}$ Apart from clothing and money, confessors also received other personal items which, like clothing, was intended to strengthen the bond between the priest and the late benefactor. For example, in 1463, Margaret, widow of the miller Sigismund, left her confessor Martin her best pillow (eyn kossen das beste). ${ }^{39}$ Barbara, daughter of the late Michael Unger, left her confessor one large silver spoon and one grivna in silver so that he could have a 'pax board' (a small devotional object used during Catholic Mass) made. ${ }^{40}$ Interestingly, Anna, widow of the belt maker (gortlerinne) Stanisław, left her confessor from Wawel Cathedral (confessori suo in Castro) 10 florins and a painting of Saint

beichtfater her Niclos Gertner VI mrc heller das tue ich dorch meyner sele selikeit”; LT, fol. 6 (1443).

"Niclas unsir caplan der polnisch prediger czu unsir liben frawen"; cons. 428, fol. 389; CONS. 428 , fol. 442.

SCAB. 6, fol. 184 (1439), 313 (1444); LT, fol. 28-29 (1452); SCAB. 7, fol. 361 (1459); LT, fol. 87 (1464) 88-89 (1466); SCAB. 8, fol. 428 (1471), 598-599 (1476).

34 The will of Barbara Putkinne; LT, fol. 11 (1448).

35 In her will, Łazaria, wife of Nicholas Slop, left her confessor, Martin, from St. Barbara's Church, another 15 o florins, which he was to dispose of according to her instructions, in addition to the six florins which he was to receive for himself.: "Czum ersten gab sy anderthalb hundert gulden dem herren Mertin irem beichtvatir zu sinte Barbare dy selben sal her haben off allen iren guttern unde Sal dy an wenden und do hyn schicken alzo her wol weis, alz sy ym hette bevolen"; LT, fol. 87 (1464).

36 "[...] swarczen mantel mit bloen leymet"; cons. 428, fol. 354 (1436).

$37 \quad$ LT, fol. 44 (1457).

$38 \quad$ LT, fol. 56 (1458).

39 LT, fol. 79.

40 "Item unum coclear melius denominavit dandum suo confessori Urbano et cum hoc unam marcam argenti pro pacificali"; LT, fol. 149-150 (1491). 
Veronica (ymaginem Veronice), which she may have used as her private altar at home. ${ }^{41}$ Anna's bequest seems to confirm the presence of images of saints in the homes of some Krakovian burghers. The existence of such objects of private, personal worship was known earlier from iconography and archaeological research, which indicate that this phenomenon was most likely relatively limited in scope. ${ }^{42}$

\subsubsection{Preachers}

After confessors, the second most commonly mentioned clergy members in the wills of Krakovian burghers were preachers. They were largely responsible for shaping the eschatological imagination of the faithful and translating complex religious teachings taken from the elite cultural sphere of the written word, into a language understandable by an often-illiterate laity. One of the great preachers of late-medieval Europe, St. Vincent Ferrer, described his mission using the following metaphor:

[T] he words of the Bible are food for the soul. Who cooks this food? The answer is: the preacher spreading the Word of God. My role is therefore not a minor one in the house of the Lord, but an important one. Like the cook who prepares food while others sleep, the preacher cooks in the kitchen of the Holy Spirit, using the fire of love and devotion and the oil of remembrance while you are asleep and resting in your beds. ${ }^{43}$

Preachers were thus teachers who, by means of their eloquence, charisma and education, were supposed to lead the faithful along the proper path in life and instil in them the appropriate forms of piety. As evidenced by the great preachers of late medieval Europe, some clergy members who performed this function were greatly respected as authority figures by the faithful, and at times even revered as living saints. ${ }^{4}$

Eight of the Krakovian testators whose wills were analysed made pious bequests to preachers. These were often generous bequests to finance perpetual prebends at St. Mary's Church or at nearby St. Barbara's Cemetery Chapel. Wealthy Krakovian burghers gathered in these places of worship to attend

\footnotetext{
$41 \quad$ LT, fol. 98 (1471).

42 Tomasz Borkowski, "Materialne przejawy codziennej religijności w średniowiecznych miastach śląskich. Drobna gliniana plastyka dewocyjna," Archaeologia Historica Polona 7 (1998), 47-54.

43 Paweł T. Dobrowolski, Wincenty Ferrer: kaznodzieja ludowy późnego średniowiecza (Warszawa: Wydawn. Inst. Historii PAN, 1996), 199.

44 As was the case with St. Vincent Ferrer and St. John of Capestrano.
} 
typical religious services or those organised by brotherhoods to which they belonged (typically Masses for the Dead). In one case, John Sweidniczer made a bequest of 21 grivna from his large estate to pay for an annuity for a German preacher who was to celebrate Mass for his soul every day for a year at the altar Sweidniczer had erected at St. Mary's Church. ${ }^{45}$ Stanisław Koczwara, in turn, made a bequest on behalf of his wife of 16 grivna in annual rent to a Polish preacher at St. Barbara's Chapel. ${ }^{46}$

45 "Item so gebe ich aws meynen guttirn Sechs hundirt ungerische gulden czu stiftunge ewiclich und of richtunge eynes Newen Altaris in meyner Capelle czu unsir libin frawen alhy in der pfarrekirche, und umb das selbe gelt sollen meyne vormonden kewfen czwenczig marg czinsis ierlichen an eyner sichern stelle of alle Quatuortempora fonf marg czu gebin also dassich dasselbe leen alleczeit selbir gebin und vorleyen sal der Dewtschen czungen prediger in der obgenanten kirchen der Dewtcz predigen wirt, das der selbe prediger das obgenante leen mit den czu gehorenden czinsen habin und dy hirschaft dorobir genissen sal alleczeitdy weyle her In eygener persone durch seynen eigenen mitten prediger und vorwesir des obgenanten stulis in dewtczer czunge seyn wordeund nicht lenger, und merklig ouch in der mosse das derselbe prediger ouch alleczeit forderlich von den Ratmannen czu Cracow und von dem pfarrer der obgenanten kirchen irwelit und irkorn werden sal, und bey dem stule seyn, und dem selben prediger allewegedy Ratmannen czu Cracow czu dem selbin Altare antworten sollen also lenhern und nemlich das iczlichir solchir prediger als vorgeschribin ist vorbunden seyn sal czu bestellen und schicken, das alle tage eyne messe obir das gancze iar sal in meyner vorgenanten Capelle gelesin werden durch sich und andire prister do Im sollen teglich also gelesin werden als am Suntage von dem tage, am Montage vor dy toten, am dinstage von der heiligen dreyfaldikeit, an der mitwoch von sinte Stanislao und sinte Bernhardino adir von eynem Merterer, am donirstage von dem heiligen leichnam, am freitage von dem leyden Cristi, am Sonnobinde von unsir frawen. Wenne sichs abir geburit das heyligetage gefallen an welchin tag dy in der wochin komen so lese man dy messe von dem selbin heyligen. Item obir dy czwenczig marg czinsis dy vorgeschriben und benant seyn, sal das obgenante altare mit eyner besundern marg ierlichis czinsis bewocht werden von meynen guttirn dy ich dorczu benume [...]. Item so sollen meyne vormonde kewffen eynen guttirn ornat czu meynem altare in meyner Capellen vor den dewtczen prediger"; LT, fol. 43-44 (1457).

"Item dixit quod villa Prokoczin domine Elizabeth uxoris sue esset et non sua, et quod solum nomine tutele legittime ipsius uxoris sue eam tenuisset et rexisset, sed tamen cum presentanes consensu eiusdem uxoris sue voluit super censibus ipsius ville fundari fundacione perpetua XVI marcas denariorum annui census pro predicatore Polonico pro ambone in capella sancte Barbare in cimiterio beate virginis sita et quia id de predicte uxoris sue personali consensu et spontanea voluntate fuit et est fundat iam ipso facto, ita quod dicta uxor sua, et poste am ipsius ville possessores et heredes de dictis ville censibus iam et deinceps singulis annis huiusmodi XVI marcas denariorum census fundacionis Domino Doctori moderno et cuilibet poste um in eadem capella predicatori polonico, qui cum dominorum Consulum voluntate et consensu et non aliter ad hoc deputatus et electus fuit dare solvere et presentare debet et debent in perpetuam eiusdem predicacionis officy salariacionem, dotacionem et presentacionem pro sua suorumque ac fidelium amicorum salute"; LT, fol. 70-71 (1461). 
Poorer burghers made less generous bequests, in accordance with their means. In both versions of his will, Peter, the administrator (sottys) of the village of Filipowicze, bequeathed his house to fund an altarage to support a German preacher at St. Mary's Church. ${ }^{47}$ In turn, Stephen Eichorn and his wife Margaret left 100 florins to the acting altarist (zu dem predigerstule), ${ }^{48}$ while John Raisser of Memmingen made a bequest of one florin in annual rent to his preacher. ${ }^{49}$

Some testators made more symbolic bequests. For example, Ursula, daughter of the councillor George Szwarcz, left two florins to a preacher at St. Mary's Church and one florin to a preacher at an unnamed hospital (probably the hospital of the Holy Spirit)..$^{50}$ Matthias, a milliner, made a bequest of one florin to a preacher at St. Barbara's, ${ }^{51}$ while Margaret Grobniginne instructed the executors of her will to pay for preachers to say a Mass for her soul each year at Krakow churches. ${ }^{52}$

Most of the testators above were members of Krakow's elite, and their pious bequests for preachers were usually part of larger plans to found altarages that

47 "Item domum suam sitam on platea Sutorum in qua Hufnayl moratur, confert et dat dominis Consulibus Cracoviensibus, qui plenam proprietatem habere debent vendendi domum ipsam, qua vendita emere debent ipsi domini Consules pro pecuniis exinde provenientibus censum quantum melius possunt pro nova et perpetua fundacione altaris in Ecclesia beate virginis parochiali, ubi ipsum altare ipsis dominis apcius fundandis visum fuit, cuius Altaris ipsi Consules perpetui erunt patroni, convertereque et conferre et appropriare debent domini Consules ipsum censum fundandi altaris pro predicatore Theutonicis iam dicte Ecclesie et non alio pro tali videlicet predicatore Theutonico, qui de assumpcione et voluntate ipsorum dominorum eiusdem Ecclesie pro tempore predicator fuerit Theutonicus, ita quod dum predicator pro tempore existens, vel licenciatus ab ecclesia fuerit aut moreretur, vel alio modo ipsum sedere predicacionis vocare contingerit, alter qui ipsi sede et officio ex dominorum predicatorum susceptione et voluntate prefuit, et quoad predicator extiterit ipsius altaris et census ex Iurepatronatus dominorum et presentacione dominis et possessor erit Predicator autem talis per se vel per alium sacerdotem duas missas super ipso Altari legere sit asstrictus unam pro defunctis, et aliam in honore beate virginis pro anime sue salute"; LT, fol. 28 (1452), 66 (1460).

48 CONS. 429, fol. 557 (1476).

49 " [...] das her ym dy Jorczeyt halden und vorkundige off dem predigestule got vor ym bittende und das lehen des selbigen altaris sullen czu vorleyen haben seyne nehesten frunde czu ewigen tagen, och hot gewolt das der selbige altar eynliczigk sal seyn das ist das der altarista heyn bevesiren merr haben magk wenn das alleyne und ouch das nicht vorwegksiln im der patronen willen und wissen och was seyn wille das alle das oppir das off den altar geoppirt worde das sal des altaristen seyn"; SCAB. 8, fol. 598-599 (1476).

$5^{\circ} \quad$ LT, fol. $56\left(145^{8}\right)$.

$5^{1} \quad$ LT, fol. 5 (1440).

$5^{2}$ " [...] und do von sal her in den kirchen dy prediger ausrichten, daz man eyn gancz iar vor ire zele bitte"; LT, fol. 66-67 (1460). 
were to be carried out by respected clergymen, which increased the prestige of the foundation and the quality of the pastoral services. The vast majority of these bequests were made to preachers at St. Mary's Church, i.e. to the most important parish church in the city. For example, in the first version of his will from 1439, John Sweidniczer appointed Nicholas of Brzeg, ${ }^{53}$ a doctor of theology and preacher at St. Mary's Church, as one of the executors of his will. Stanisław Koczwara, in turn, named in his will a certain Doctori moderni, who was a preacher at St. Barbara's Chapel. ${ }^{54}$ The fact that the preachers in Krakow's most important Churches were highly educated and well-respected assuredly played an important role in testators deciding to make bequests to these institutions and their clergy.

It should also be noted that Krakovian burghers would clearly indicate whether they wished to support a German or a Polish preacher. This was certainly an indication of a testator's desire to hear sermons in their native tongue. But this decision also reflects the rivalry between the German-speaking and Polish-speaking populations of Krakow that had been ongoing since at least the late fourteenth century. 55

\subsubsection{Other Clergy}

There is no doubt that apart from confessors and preachers, other clergy also played an important role in shaping the religious life of Krakovian burghers. Since Krakow parishes were usually large, making it difficult for individuals to identify with the parish community as a whole, an important link between burghers and the Church was the clergymen with whom they had close contact. In making pious bequests, many testators did not fail to include clergymen in their last wills. The very first known Krakovian testator, the burgher woman Sulisława, named in her will priests from two monasteries, making pious donations to both of them. She left half of her market stall to the Dominicans, with whom resided a priest named Michachel, son of Simnikonis; ${ }^{66}$ the other half she left to the Franciscans and a resident priest named Minardus. ${ }^{57}$ Two other widows, Alusza and Dorothy Banarika, made similar bequests in their wills. Alusza left three grivna to the hospital of the Holy Spirit and one

\footnotetext{
53 "Niclas vom Brige dem doctor der heiligen schrift prediger zu unser liben frawen"; cons. 428 , fol. 402 .

54 LT, fol. 70-71 (1461).

55 Hanna Zaremska, Bractwa w średniowiecznym Krakowie, 37.

56 "Item de instita sic dispono, quod mediam confero fratribus predicatoribus, in qua Michachel filius simniconis residet"; KDM K, vol. 3, no. 368.

57

"Insuper mediam institam do fratribus minoribus, in qua minardus inhabitat"; ibidem.
} 
grivna to a brother named Nicholas who worked there. ${ }^{58}$ Dorothy Banarika specified in one of her wills that a bequest was to be made to a presbyter, also named Nicholas the 'Crusader' (Cruciferus) from Kalisz. ${ }^{59}$ This presbyter was probably a member of the Order of Canons Regular of the Holy Spirit, which ran the hospital of the Holy Spirit in Kalisz. ${ }^{60}$

The wills of the mine administrator Paszko and councillor Gotfrid Fattinante contained numerous specific bequests. Paszko drafted his last will when he was already very sick, bequeathing some of his clothing to clergymen. His instructions were very specific: "I leave my coat lined with marten fur to brother Bartek. I leave my other brown coat with a lining to brother Gregory and my blue coat and tunic to Bogusław, the parish priest from Osiek. I leave my two silver belts to brother Gregory so that he can turn them into a chalice or two cruet bottles." ${ }^{11}$ Such bequests seem to testify to strong bonds existing between the testator and his beneficiaries. Councillor Gotfrid Fattinante also made numerous and generous pious bequests, including the funding of two new altars. He named two close associates as their altarists: a vicar named Peter and a priest named John, who were, respectively, his notary and his doctor. ${ }^{62}$ Naturally, it is also possible that some of these bequests were made to priests and monks who were relatives of the testator. ${ }^{63}$ However, when priests and monks related to the testator were mentioned in bequests, they were included not only because they were family members, but also because they had been entrusted with securing the testator's immortal soul. ${ }^{64}$

It is worth pointing out here the frequent mistrust shown towards people of the Church, expressed in provisions guaranteeing the future of foundations created in the event of a clergyman's failure to carry out the duties entrusted to him. For example, Catherine, widow of the goldsmith George, stated in her will that Andrew of Wróblewo, permanent resident Vicar (Vicar

$5^{8} \quad$ "Item Legauit infirmis ad hospitale denariorum grossorum tres marcas et Ibidem ffratri Nycolao vnam marcam"; NKiRMK, no. 616 (1321).

59 “[...] tem domino Nicolao Crucifero in Kalis X mrc"; sCAB., no. 1866.

6o Klara Antosiewicz, "Zakon Ducha Świętego de Saxia w Polsce średniowiecznej," Nasza Przesztość 23, 1966, 175 .

61 "Item Palium cum pellibus Marderinis demandauit fratri Bartkoni. Item aliud palium bruneticum cum Subductiua fratri gregorio. Item Palium flaueum cum tunica domino Boguslao plebano in Ossek. Item duos Cingulos argenteos fecit dare fratri Gregorio pro Calice aut pro duabus ampullis"; NKiRMK, no. 1693 (1358).

62 KDWac., vol. 2, no. 396, 182-185 (1393).

63 See chapter Three.

64 For example, Dorothyo Reichelinne left 20 florins to her brother Thomas, a Cistercian monk from Koprzywnica, for the clothes he needed. To make this donation more significant, she also donated 10 florins to the monastery; SCAB. 8, fol. 203 (1465). 
Perpetuus) of the Krakow cathedral, was to either personally celebrate Mass at the altar she funded or appoint someone in his place, under the threat of excommunication. ${ }^{65}$

\subsection{Religious Objects in Wills \\ 1.2.1 Rosaries}

Private worship, free of intermediaries, was possible only through the practice of individual prayer. Although the Church advised the faithful to kneel and say the Hail Mary whenever they heard a bell ring (usually two or three times a day), ${ }^{66}$ in order to instil in them the habit of praying, for the majority of burghers prayer remained a public ritual. Nevertheless, in the fifteenth century, evidence can be seen of a deepening religious awareness among burghers. Improvements in literacy and, as a result, people's knowledge of religious texts, coupled with the wide array of church institutions operating in Krakow, made it possible for conscious choices to be made about how the liturgy was taught and conducted by the Church and for personal preferences to develop. One sign of people's engagement in private, personal forms of religiosity was the habit of praying individually, of which the rosary was a visible symbol in the Middle Ages.

Rosaries, or Pater Nosters, are first mentioned in municipal books in the 143os. However, 'praying the rosary' most likely did not become popular in Krakow until after the mid-fifteenth century, as evidenced by a document dated 1484 in which Pope Innocent VIII offered indulgences to the members of the brotherhood of the Psalter of the Blessed Virgin Mary in Krakow: "According to Alain de la Roche, a brotherhood with such a name should have been devoted to praying the rosary. We can thus assume that this document is the oldest trace of the existence of such a brotherhood affiliated with the Dominican Order in Krakow." 67 The fact that rosaries were frequently mentioned in wills

65 "Item rogavit Ipsos dominos Consules et executores qui presentes fuerunt et postnotandos quibus pro hac vice dumtaxat Iuspatronatus donavit ut huiusmodi altare sive ministerium per ipsos pro huiusmodi pecuniis disponendis et emendis primum altaristum presentent honorabilem dominum Andream de Wroblewo vicarium perpetuum in Ecclesia Cathedrali Cracoviensi cuius vitam mores et bonam conversacionem bene noscere asserebat presentandum nominavit et voluit quem sub consciam suam obligatur et obligat ut ad huiusmodi fundacionem altare operam et diligentiam faciat et per se vel per alium huiusmodi missas sicut moris est sub pena excomunicacionis impleat et celebret ac de censibus pro huiusmodi ministerio comparandis gaudet"; LT, fol. 142 (1484).

66 Stanisław Bylina, Religijność mieszkańców Europy Środkowo-Wschodniej, 106.

67 Katarzyna Zalewska, Modlitwa i obraz. Średniowieczna ikonografia różańcowa (Warszawa: Wydawnictwa Uniwersytetu Warszawskiego, 1994), 17. 
demonstrates that there was a strong link between wills being written with the intention of securing salvation and the rise of new forms of piety, symbolized by, among other things, praying the rosary, as indicated by relatively frequent references to rosaries in testaments of last will.

The oldest mention of rosaries in a will dates back to at least 1431. Councillor Paul Homan testified before the municipal bench court that his late wife's sister received her coral rosary and golden ring as a gerade. ${ }^{68}$ In 1440, as many as three rosaries were listed in the will of the wealthy stallholder Martin Streicher (he was probably related to councillor Stanisław Streicher, who is mentioned in the will). ${ }^{69}$ In addition, a silver belt with a pouch containing a coral rosary and a medallion with the image of Saint John the Evangelist were included among Streicher's valuables in his will. ${ }^{70}$ The wealthy burghers Martin Pasternak in $1458 ;{ }^{71}$ Elena, the wife of the embroiderer (zeidenhafter) Nicholas in $14767^{72}$ and the tailor Jarosz in $1492^{73}$ also listed in their wills two coral rosaries as movable property. John Landandis mentions a rosary in his 1472 will. ${ }^{44}$

Testators also specified what material rosaries were made of (they always chose precious coral), which demonstrates that they were valuable objects. In her 1501 will, Margaret Czypserowa, an affluent burgher woman, left her coral rosary (legibulum alias paternoster de corall), which she listed alongside her twelve rings, to her children. This demonstrates that rosaries were included in some wills on a par with other valuable objects and movables, and that testators sought to ensure they would be inherited by a worthy heir. On the other hand, as other documents demonstrate, some rosaries were included in the will because they had purely symbolic or emotional value. Testators for whom this was true were predominantly wealthy, religious and most likely literate Krakovian burghers. This is evidenced by Krakow's municipal books: in 1451, Barbara, widow of the deputy prosecutor (procuratoris) Henry, testified that the objects she had pledged to councillor Nicholas Zalcz, including four books, a rosary

68 sCAB. 6, fol. 29 (1431).

69 "Dy nochgeschreben gerethe hot lossin beschreiben her Mertin Streicher von irsten C gereinte gulden und XXII gulden ist mir scholdig Stana Streicher"; LT, fol. 5; cf. Marcin Starzyński, Krakowska rada miejska w średniowieczu, 270.

"Item eyn zilberen gurtil von VI marg groschen und zust eyn cleyn selberin gurtil von czwu marg silber mit eyner kaletin und in der Caletin ist eyn korallin potirnoster und czechin Johannes primus"; LT, fol. 5 . LT, fol. 28.

72 Advoc. Crac. 83, fol. 8-9; Cracovia artificum 1300-150o, ed. Jan Ptaśnik (Krakow: Polska Akademia Umiejętności, 1917), no. 654 .

73 LT, fol. $15^{1-152 .}$

74 LT, fol. 101. 
and a pearl necklace, were returned to her. ${ }^{75}$ While we do not know the subjectmatter of these books (considering the profession of Barbara's husband, they were probably law books), it is evident that Barbara and her husband were literate. Moreover, the couple must have been both pious (hence the rosary) and of high social status (as evidenced by the pearl necklace). ${ }^{76}$ Another interesting example is the will of Nicholas Paternoster. His name suggests that he was either a very pious Christian who prayed the rosary, or someone who manufactured rosaries. In 1450, the year of the great Roman Jubilee, Paternoster drafted a will before embarking on a pilgrimage to Rome. ${ }^{77} \mathrm{He}$ instructed the executors of his will to sell his house and use the money to make pious bequests to the Church of Corpus Christi in Kazimierz (4o florins), the brotherhood at St. Barbara's Church (2o florins), and one of his relatives (only fifteen florins). The rest of the money was to be donated to opera pietatis. ${ }^{78}$ Nicholas must have been very religious, because in addition to making pious bequests and a pilgrimage to Rome, he also specifically stated in his will that all his household items, including his books, should be donated to poor priests and laymen. ${ }^{79}$ As with the other examples discussed above, the fact that Nicholas possessed religious books can be seen as proof of his interest in a deeper, more individual form of worship. It also demonstrates that in the late Middle Ages, the rise of literacy and new elite forms of religiosity were interconnected.

\subsubsection{Books and Paintings}

As mentioned above, increasing levels of literacy were closely connected with more intimate and intentional forms of piety, of which wills were undoubtedly a sign. Writing not only revolutionized trade, governance and social relations within the city, it also helped shape a new mentality, one more accustomed to planning, rational evaluation and intellectual engagement in religion. ${ }^{80}$ While

75 "Barbara relicta Henrici procuratoris recognovit quod Nicolaus Zalcz quatuor libros, paternoster et collerium margaritheum et ceteros res quasi ipsa una cum viro suo eocem ipso vivente ipsi Nicolao pro censu presesso obligaverat integre et omnimode restituit pronuncians eum de eisdem totaliter liberum et solutum"; cons. 428, fol. 32.

76 Mentions of rosaries can also be found in the entry concerning its inheritance; cons. 429, fol. 516 (1474) and in another one in which it was pledged together with other valuables.: "als eyn ledchyn do ynne sint 7 silberene leffil, 3 hauben mit golde gestructit und eyn cleyn obirgolt gortleyn das hot 7 spange ane den senkil, eyn korallen paternoster, eyn cleyne perlen przeniczkyund eyn bendil mit perlen und eyne haube"; sCAB. 8, fol. 428 (1476).

77 SCAB. 7 , fol. $43,47(1448,1450)$.

78 The remaining money was to be divided among the poor, lepers and "czu wege und czu stege"; SCAB. 7, fol. 43 (1448).

79 Ibidem.

8o Jack Goody, The Logic of Writing, 59-65. 
the limited number of available sources containing references to literacy among burghers, or the books they read or possessed, do not allow for an accurate determination of the scale of this phenomenon, literacy continued to be increasingly commonplace in the lives of burghers throughout the fourteenth and fifteenth centuries. For reasons of both practicality and prestige, the first literati in the burgher community were city officials and merchants, two social groups with strong mutual affiliations. It is estimated that the majority of Krakow officials and merchants were able to read and write by the mid-fourteenth century. ${ }^{81}$ As the oldest known Krakow municipal book indicates, literate burghers did not treat reading and writing merely as a practical skill, but also as a means for expanding their intellectual horizons. The book includes an entry showing that the municipal notary Peter lent the alderman (and future councillor) John Puswange the pseudo-Aristotelian book Secretum Secretorum and three other works (published in a single volume). ${ }^{82}$

Fourteenth-century bequests of last will generally do not mention valuable or personal items. Books belonging to the testators or their family are mentioned only in two wills. In his 1368 will, Nicholas Essenbach divided his estate, stating that his nephew should be given an annuity, all his books and ten grivna, provided he obey and serve Nicholas's wife, attend school and become a clergyman. ${ }^{83}$ The example of a book of accounts that Catherine, widow of alderman Paul Kowal, was to give to her brother-in-law John Bertram (after receiving the money promised to her in the will) expresses a more pragmatic approach to books and literacy. ${ }^{84}$

An inventory of accounts between the merchant Henry Steinmoler and the alderman (and future councillor) Stanisław Morsztyn and his brother George Morsztyn, also a merchant, drawn up in 1451, included three books, the Katolicon, a book by Avicenna, and the Bible, which the latter was to reclaim in Antwerp. ${ }^{85}$ The selection of books demonstrates that Krakow's elites were indeed

81 AgnieszkaBartoszewicz, Piśmienność mieszczańska w późnośredniowiecznej Polsce, Warszawa 2012, 34-35.

82 "Petrus notarius concessit librum Secretorum Aristotelis et alios tres in uno volumine Iohanni Puswange"; CONS. 427, fol. 28 (1393).

83 " $[. .$.$] dicta domina Katherina Petrum filium sororis sue circa se sibi ministrandi vite nec-$ essaria pro suo posse in quantum ipsam et scolas sequi voluerit ac sacros presbiteratos ordines mutari et ipsum in libris suis cum X mrc"; cf. SCAB., no. 242.

84 "[...] item promisit librum racionis vel debitorum sui mariti quod velit ipsum fratri sui mariti assignare"; SCAB., no. 1502 (1392).

85 "Ouch bekante her daz dy schulde bey den wirthen czu Magdeburg und Brawnczweig sint Stano und Jorge Mornsteyn und nicht seyn und dorczu allis grethe das in dem lande bey der wirtynne czu Antwerpin ist alz drey bucher Katolicun, Avicenna und eyn Biblia, eyn 
religious, but also that they had broader intellectual horizons. ${ }^{86}$ Naturally, Krakovian burghers also owned practical and 'everyday' books that they could use to advance their professional knowledge. A list of councillor Stanisław Leymitter's possessions, drawn up by aldermen after his death, included three law books. ${ }^{87}$ The municipal notary Nicholas Knoll (Schonberg), who inventoried the possessions of the late Herman, a physician (magistri Hermanni Phisici), received a chest containing his books and other possessions. ${ }^{88}$

Books were also mentioned in the wills of two important figures in fifteenth-century Krakow, namely one of the city's wealthiest and most influential burghers, John Sweidniczer, ${ }^{89}$ and a widely respected municipal notary and altarist at St Mary's Church, John Stolle of Głogów. ${ }^{90}$ In an extremely long and meticulous listing of all his goods, liabilities and assets, John Sweidniczer mentions "all my books," including two or three which at the time had possibly been lent to the parish priest (dem pfartor) at St. Mary's Church. Like other burghers who owned books, John Sweidniczer probably had many books on different subjects, both secular and religious. ${ }^{91} \mathrm{~A}$ former student of the universities in Prague and Krakow and a municipal notary by profession, John Stolle had an even larger book collection. ${ }^{92}$ Three versions of his will are known to

silberynne schale, eyn swarcz mantil mit growerg, eyn swarcz rock mit mardern gefuttirt, eyn groer rock mit fochsen und ander cleyn gerethe das do frey und unforkommert ist"; cons. 429, fol. 36 (1451); cf. Adam Kamiński, "Jerzy Morsztyn (żupnik)," in PSB, vol. 21 (Wrocław-Warszawa-Krakow: Polska Akademia Nauk, Polska Akademia Umiejętności, 1976), 816-817.

86 The horizons and intellectual ambitions of the city's elites are evidenced by the fact that in the fifteenth century many representatives of the Krakow patricians (including many members of the Morsztyn family) were enrolled as students at University of Krakow; cf. Krzysztof Boroda, Studenci Uniwersytetu Krakowskiego w późnym średniowieczu, 122-124; Edward Potkowski, Ksiażka i pismo w średniowieczu. Studia z dziejów kultury piśmiennej i komunikacji społecznej (Pułtusk: Wyd. Akademia Humanistyczna im. Aleksandra Gieysztora, 2006), $75^{-88 .}$

87 " [...] acht margk silber, drey recht bucher, czwe panczer und eyn kolner, das beste hantfas, czwene kasten, drey tysche, czwe bette vunf steyne czenen gefese, schofseln kannen scheyben, sechs leichlach, eyne grune tafter decke, czwene tepicht, eyn langen und eynen korczen bancfel, eyn banclach mit eynem cleynot"; cons. 429, fol. 368 (1465).

88 CONS. 428 , fol. 520,534 (1449).

$89 \quad$ LT, fol. 39-45 (1457).

9 SCAB. 6, fol. 186 (1439), 187 (1439), 267 (1442); CONS. 429, s27-28 (1451); KDMK, vol. 3, no. 439, $574-576$ (1454).

91 It is noteworthy that Sweidniczer employed a private tutor and made one of his bequests to him; cf. Agnieszka Bartoszewicz, Piśmienność, 263.

92 "Born in Głogów, he obtained his bachelor degree in Prague in 1407. In 1414 or 1415, he enrolled at the University of Krakow and at the same time was employed in the local municipal office (August 1414). However, in 1415 he left Krakow to study in Vienna, but 
have been drafted, two of which were written in both Latin ${ }^{93}$ and German. ${ }^{94}$ In the first, John Stolle left his impressive book collection (approximately 25 books; ten manuscripts have survived to the present day in the Jagiellonian University Library, including liturgical works, sermons, and books on science and the law) ${ }^{95}$ to his housekeeper (schafferinne), along with other goods. Stolle further instructed that after the death of his housekeeper the books should be used to fund four altarages at St. Mary's Church. ${ }^{96}$ Twelve years later, in 1451, Stolle confirmed the final version of his will on his deathbed. This time he donated all his books on the liberal arts (Latin in artibus, German in der freyen kunsten) to the University of Krakow, stating, however, that his successor Nicholas Knoll (Schonberg) could choose two or three books to keep "for the memory of my soul" (pro memoria anime mee). In addition, Stolle left his "old collection of prayers bound in white wood" (in German Meine alde Collecta in weissen bretin, in Latin Collecta mea antique in albis asseribus) to John, a former deputy notary at the Church of Corpus Christi. Stolle left all his theological books and the Maius volumen Prisciani, a textbook of Latin grammar, to St. Mary's Church. ${ }^{97}$ It is perhaps not surprising that John Stolle named John

soon returned to the Wawel Castle and the local municipal office. A quarter of a century later, he was very wealthy, associated with the circles of the Krakow patricians. He disposed of his wealth in his will, which he wrote in 1450, not as a municipal notary, but as an alterist at St. Mary's Church"; ibidem, 163; cf. Bożena Wyrozumska, Kancelaria miasta Krakowa w średniowieczu, 121.

93 SCAB. 6, fol. 187 (1439), 267 (1442); KDM K, vol. 3, no. 439, 574-576 (1454).

94 SCAB. 6, fol. 186 (1439); CONS. 429, fol. 27-28 (1451).

95 AgnieszkaBartoszewicz, Piśmienność, 187; Krzysztof Skupieński, Notariat publiczny w średniowiecznej Polsce (Lublin: Uniwersytetu Marii Curie-Sklodowskiej, 2002), 128-129; Marcin Starzyński, "Kto był pisarzem Kodeksu Behema?," Rocznik Krakowski 73 (2007), $67-69$.

$96 \quad$ "Czum ersten bescheyde Ich Dorothee meyner Schafferynne der Bochnerynne swester meyn haws in deme Ich wone of der spitler gasse, czwischen der Felixynne und der faberynne hause czu irem leben, und nicht erblich und dorczu meyne bucher und cleider, und bettegewand, gefolle hawsgerethe, bawierot, geld und alle meyne varende habe keyns ausgenomen, ir czu lone vor ir dinst," "Primo Dorothee dispensatrici mee sorori Bochnerynne lego domum mea in qua habito in platea hospitalensi inter domos Felixynne et Faberynne ad vitam ipsius et non hereditarie possidendam, et cum hoc libros meos et vestes, lacristernia, vasa, supellectilem, utensilia, pecuniam et queque mobilia mea nulle excepto pro ipsius primio deservito"; SCAB. 6, fol. 186-187 (1439).

97 "Item omnes libros meos in artibus do ad Collegium hic in Cracowia, Ita tamen, Quod Nicolaus Schonberg predictus sibi vnum, duos vel tres libros ex ipsis libris qui sibi placebunt, recipere debet, pro memoria anime mee. Eciam lego ad Corpus christi Kazimirie domino Iohanni quondam Vicenotario Collecta mea antique in albis asseribus, Omnesque libros meos in Theologia magnos et parwos, nullo excepto, et maius volumen Prisciani ad laudem et honorem beate virgini ac imperpetuum ei servicium do pro domo 
Sweidniczer and the aforementioned notary Nicholas Knoll ${ }^{98}$ as the executors of his will, as they had worked together in the city hall, shared a similar social standing, and probably also shared similar interests.

Stolle's and Sweidniczer's impressive private book collections must have been exceptional in medieval Krakow. Indeed, Stolle and Sweidniczer were themselves exceptional individuals, members of the city's intellectual elite, the highest echelon of a kind of 'fourth estate' - what they would call, in French, les gens de savoir. ${ }^{99}$ However, burghers who possessed less cultural capital also displayed higher intellectual ambitions. ${ }^{100}$ Both Nicholas Paternoster and Margaret, widow of Lawrence Neyser (Margaretha Lorencz Neysserinne), neither of whom were representatives of Krakow's patrician families, also listed books (probably religious works) in their wills. In Nicholas Paternoster's will, books were mentioned in a very casual manner, alongside his other movables, including sheets and bedclothes. ${ }^{101}$ Margaret's case is also noteworthy. From the note of agreement between her son Stanisław Slepkogil and daughter Catherine Dittrichinne we know that among Margaret's movables in the will were listed

sua ad Ecclesiam parrochialem"; cons. 429, fol. 27-28 (1451); KDM K, vol. 3, no. 439, 574576 (1454).

98 He paid homage to Stolle, calling him "his dearest master' in the obituary he wrote for him in the council book."; cons. 429, fol. 18; Bożena Wyrozumska, Kancelaria, 122.

99 Agnieszka Bartoszewicz, Piśmienność, 36-41.

100 "The claim that lay people used books primarily for didactic and professional purposes seems to be true. But the example of Sweidniczer's will shows that there were also religious motives. Many burghers had prayer books, many also showed interest in the life and deeds of Jesus, Mary, other figures from the New Testament, and the saints. Burghers may have also been interested in some historiographic literature, and The Alexander Romance was definitely a major one. Latin grammar textbooks, prayer books, and the lives of saints were undoubtedly in the greatest demand from booksellers trading in manuscripts and printed books. Prognostic calendars with lists of lucky and unlucky days and various types of guide books should be added to this list. The library of Anna Kuncz, a Vilnius dressmaker who had collected five books, including some chronicle, the prophecies of St. Brigid, a book concerning botany and medicine, and a medical book ("ayns Joannis paulery, ayns Sante Brigitte, ayns Dy Cronika, das wyrde herbarium, das ffunfte cyrurgia") probably quite accurately reflected the interests of the burghers. The book collection of John Parzykozeł from Krakow was more ambitious: Speculum Saxonum, a book on church law, grammar textbooks including the inevitable Donatus and Alexander de Villa De, the Adagia by Erasmus of Rotterdam and an edition of Aesop's Fables."; Agnieszka Bartoszewicz, Piśmienność, 265-266.

101 "Dornoch bescheide ich allen hausrot, bette, leylocher, bucher und allis das man finden wirt das sal man geben armen pristern und armen leuten und wo is notdorft wirt"; SCAB. 7 , fol. 43 (1448). 
a painting (das bilde) and a 'German book' (das deutsche buch). ${ }^{102}$ There is no additional information specifying what kind book this was or what the painting depicted. We can assume the painting depicted a saint and was used as a kind of private altar in her home, as was the case with the painting of Saint Veronica that Anna, widow of the belt maker Stanisław, donated to her confessor at the Wawel Cathedral. ${ }^{103}$ If we take into consideration Margaret's wealth and social standing, it seems probable that she was literate, and that the book was probably a religious work.

Some wealthy Krakovian burghers not only bought and read (mostly religious) books, but also used them as security and donated them to religious institutions. For example, Bernard Filip of Lubojna states in his will that the parish priest Thomas from Mikanów pledged his book for 36 groszy. The testator stated that the priest had to say thirty Gregorian Masses (tricesima) for the release of Bernard's soul to get back his sacramentary (a book containing the sacraments). Should he fail, a different priest should say the Masses, and the sacramentary and Bernard's other books should be given to poor students. ${ }^{104}$ We thus know for certain that Bernard Filip owned not only the one sacramentary, but also other books (unfortunately, we do not know what kinds). ${ }^{105}$

Other burghers (including women) who made religious books part of their foundations likewise must have participated at some level in so-called written culture. This is demonstrated by their bequests, which in themselves are expressions both of respect for the written word and evidence of how it was tied to religious activity. Like Bernard Filip, Bartholomeus, a tanner, also left his books to various religious figures and institutions, including a donation to the

102 Her son's name indicates that her first husband could have been councillor John Slepkogil or some other member of this wealthy family from Krakow. Catherine's daughter was married to a Krakow alderman and future councillor, Nicholas Dietrich; Marcin Starzyński, Krakowska rada, 270, 283.

103 LT, fol. 98 (1471).

104 "Item unum librum dictum Sacramentale quem sibi per dominum Thomam plebanum in Mykanow in vadiatum existit in tribus fertones si et inquantum ipse dominus dictum librum rehabere cupit legit unam tricesimam pro anima sua extunc recipiat librum si ea facere nequit convemat alium legentem pro dicta pecunia et librum recipiat pro se. Item omnes libros legavit propter deum pauperibus scolaribus"; LT, fol. 71 (1461).

105 This is probably how the Book of the Viaticum found its way into the hands of a Krakow Jew, Israel. "Ysrahel der Jude hot angeclagit frawe Nethen Hanusynne das her hette eyn buch eyn viaticum bey yr gefunden der ym in dem fewer genomen were. So hot dy frawe Netha gesprochen das yr das buch in eymen phande vorsetczit were von eynen Lithyn der heysit John Lithwyn und den sal sy gestellen czwuschen hyr und Stanislai noch Ostern nehist komende"; cons. 429, fol. 619 (1478). 
Bernardines of a new missal, whose "writing had begun" and would be finished using Bartholomeus's money. ${ }^{106} \mathrm{~A}$ similar bequest was made by the wealthy alderman and furrier John Kunisz, who donated a missal worth three florins to the chapel of the furriers' guild at St. Mary's Church. ${ }^{107}$ Burgher women were also involved in such 'literary' religious practices. For example, in her 1430 will, Catherine, wife of Henry Schendel, made a bequest (among numerous others) of 20 grivna to the school at St. Mary's Church for the purchase of a book for its students. ${ }^{108}$ In the same way, in her 1433 will, Catherine, wife of the glassmaker Nicholas, donated six grivna to St. Mary's Church for the purchase of a new psalter. ${ }^{109}$

Bequests by members of Krakow's elite of missals for private altars played a somewhat different role. Affluent burghers wished to provide all the necessary 'equipment' for the altars they funded to ensure that the priest saying Mass could carry out his duties, but they also wished to display their wealth and demonstrate their piety. Some testators even personally selected the missals and other essential elements (chasubles, chalices, silver cruets) to be used at 'their' altars and chapels as a means of demonstrating their religious knowledge and devotion. For example, the notary John Stolle donated an old Roman missal (in German eyn gerecht ald romisch messebuch, in Latin vetus Romanum missale) for the altar he funded, ${ }^{110}$ while John Sweidniczer donated a missal, chasuble, and other items necessary for 'his' altar. ${ }^{111}$ Evidence that Stanisław Plesner donated a missal to support the founding of a new altarage is provided by extant sources from 1437 pertaining to a dispute among his relatives. ${ }^{112}$ Salomea, widow of the goldsmith Nicholas Brenner, found it necessary for the altar at St. Mary's Church she funded in her will to be equipped with a

106 "Item fratribus ad sanctum Bernhardinum decem marcam pro vestitura et missale quod iniciatu est scribi debet terminari de bonis suis et confirmatum ibidem dari, et si fieri poterit, sive dampno puerorum pro casula octo vel nonem florenorum ibidem eciam tribuentur"; LT, fol. 35 (1455).

107 "Item so bescheide ich of der korszner cappelle zu unsir liben frawen III gulden czu eynen meszbuch czu andirsnichtis anczuwenden"; LT, fol. 127 (1481).

108 "XX czu unsir liben frawen czu eym buche den schulern"; sCAB. 5, fol. 203 (1430).

109 "Item czu den singbuchern czu unser liben frawen vi mrc heller adir wo man is andirs wo bedorffin wirt”; LT, fol. 6 (1443).

110 SCAB. 6, fol. 186, 187 (1439).

111 "Item so sollen meyne vermonde kewffen eynen guttin ornat czu meynem altare in meyner Cappellen vor den dewtczen prediger. Item ouch sal dorczu eyn messebuch das do gancz ist, und drey kazeln dy ich vormols habe"; LT, fol. 44 (1457).

"Ouch sal der egenante Hannus Foit so dy voitey czu der Newenstat wedirgehabit wurde durch bote adir durch recht czum ersten dem Testament seyns ohmen Stano Plesners genugtim und das vor alle andern sachen ausrichten mit XII marken gr ierlichis und ewigis czinsis du mit eyme Messebuche und eyner kazil"; cons. 428, fol. 377 (1437). 
chasuble, chalice, and missal. ${ }^{113}$ Similar bequests were made by others, including Paul Ber, who equipped 'his' altar with a "large new missal";114 mine administrator Matthias Muscala, who planned to found two altarages for which he had earlier provided missals, chalices and chasubles;115 and Peter Schepcz, who donated "to his chaplain" Kacper, who was to be the altarist of a new altar: two chasubles (kasseln), a chalice, missal, platter (pater) and two silver cruets weighing four florins. ${ }^{116}$

In light of the above observations on the rise of literacy and the popularity of religious books (among other types of book) among Krakow's elite, it seems no coincidence that, as wills grew in popularity in fourteenth-century Krakow, most were made by members of the municipal council, aldermen and wealthy merchants. Wills were one manifestation of the close link between the rise of literacy and the spread among the elite of a model of personal religious devotion (which did not exclude participation in traditional communal forms of worship). The fact that wills in some cases were handwritten by testators seems less important than the more general fact that a certain group of people thought it necessary to leave behind a written last will after their death. ${ }^{117}$

A person who wished to connect with God through prayer, petitioning Him with words and gestures, most often did so at church, with Christian symbols and signs before his eyes. [...] Gradually, objects of personal devotion, such as home altars, reliquaries and images of saints, became increasingly widespread. They were no longer present only in royal households and on magnates' estates, but also among the lesser nobility and burghers. ${ }^{118}$

113 "Item so gebe ich mit der tat und habe gegeben dem obgenanten Hern Mathis alle meyme gerade dy ich mir geczewgt habe, daz her do von kewffe und schaffe allirley gerete das czu eyme Eltir gehoret, also ornat, kelch, messebuch etc."; sCAB. 6, fol. 190 (1439).

114 "Ouch bescheide ich ken Grosglogow yn dy pharkirche zu synte Niclos eyne kamische kasel dy beste undir czween dy ich gereyt habe und das grosse newe Missale das man dy czwestucke alle tagen notczen sal zu eyme gedechtnisse und troste meyner elden und frunde zelen der leychnam derselbiste rasten"; SCAB. 8, fol. 270-271 (1466).

115 LT, fol. 122-124 (1479).

116 LT, fol. 137-139 (1483).

117 Notes specifying that the testator wrote his own will is found, among other places, in the wills of John Reichil, a wealthy staller, SCAB. 6, fol. 196, 256 (1440, 1442), Nicholas Newmeister, a deputy municipal notary of Krakow, SCAB. 7, fol. 120 (1451) and Peter Schepcz, a merchant, LT, fol. 137-140 (1483).

118 Stanisław Bylina, Religijność późnego średniowiecza. Chrześcijaństwo a kultura tradycyjna w Europie Środkowo-Wschodniej w XIV-XVw. (Warszawa: Neriton, 2009), 53. 
Apart from such devotional objects, small crosses and medallions depicting the Lamb of God (Agnus Dei) were also occasionally mentioned in wills. They functioned as religious (Christ depicted on the cross or as a lamb), symbolic (as signs of piety) and perhaps even magical objects that were believed to have protective powers. ${ }^{119} \mathrm{~A}$ silver cross and Agnus Dei medallion were first listed in an inventory of personal possessions taken to the town hall following the death of the wealthy burgher Nicholas Teschner. ${ }^{120}$ A silver Agnus Dei medallion was also listed as belonging to Krakow councillor Nicholas Dietrich. ${ }^{121}$ Meanwhile, we learn about an image of the Lamb of God owned by Stanisław Weingart (probably a relative of councillor Peter Weingart), ${ }^{122}$ from records relating to a dispute over the execution of his will. ${ }^{123}$ Another important figure representing both the culture of the written word and the highest echelons of burger society in Krakow was the notary Eustace, whose movables included an expensive Agnus Dei medallion made of gold and mother-of-pearl, which he left to his son. ${ }^{124}$ This prestigious symbol of Christianity was also owned by Margaret Czipserowa, who was married three times and widowed twice (her second husband was councillor Nicholas Zalcz). ${ }^{125}$ The symbolic power of both crosses and Agnus Dei medallions is evidenced by a bequest made by the goldsmith Nicholas Brenner in his 1464 will. In it Brenner listed all his settlements and accounts, including an order from the bride-to-be Łazaria (wife of Nicholas Slop) for a gilded belt, ring, cross, Agnus Dei and some hook-and-eye closures. ${ }^{126}$ This indicates that the Agnus Dei was treated as both an ornament and an important symbol of religious devotion on the bride's dress.

119 Aleksandra Witkowska, Kultypątnicze piętnastowiecznego Krakowa (Lublin:Wydawnictwo Towarzystwa Naukowego Katolickiego Uniwersytetu Lubelskiego, 1984), 215-216.

120 "Eyn cleyn crewczchin von silber, 1 silberyn agnus dei”; cons. 428, fol. 320 (1433).

121 "Item dy frawe hot bey ir eyne kostir und eyne large zeide, und iris mannis cleydir. Item sy hot bey ir silberinne gabilchen Agnus Dei zilberin kapchin zilberin leffil und II zecke mit czwebilzomen und eynen kasten mit buchner manchirlen"; coNs. 429, fol. 344 (1463).

122 Marcin Starzyński, Krakowska rada, 248.

123 CONS. 428, fol. 413 (1440).

124 "Item dorczu eyn Agnus Dei vorgolt mit eyner perlen muttir," "Item unum agnus die cum margarita perlen muter"; LT, fol. 61-63 (1459).

125 LT, fol. 165-166 (1501).

126 "Item so habe ich der frawen Lazarien Niclos Sloppottynne of ire hochczeit und ouch der thachter gemacht gortel of geslagen und forgolt und fingerleyn gemacht, creuczleyn und eyn Agnus dei vorgolt und heftleyn gemacht dofon allis czulone ist sy mir scholdig andirthalb marg hellir"; LT, fol. 83-84 (1464). 


\subsection{Participation in the sacrum: Personal Belongings Used for Religious Purposes}

The division of property into 'movable' and 'immovable,' present in even the oldest codices, was more than just a medieval legal concept, it was also a reflection of a medieval mentality. The difference between movable and immovable property is best reflected in the relationship between these types of property and their owner. While real estate was seen as property that was almost independent of the owner, something held in common with members of the wider social group, movables were considered extensions of their owner's body Mobilia ossibus inhaerent. ${ }^{127}$ An identification of testators with the objects they possessed was closest in the case of personal objects, such as clothing and jewellery, but functioned to a lesser extent in relation to their dishes, bedding, tools, armour and weaponry. These things constituted the basic components of specific categories of feminine goods, gerade, and masculine goods, hergewet. ${ }^{128}$ Even people today, whose ways of thinking differ greatly from a traditional mentality, tend to identify with certain personal items, believing they in some way express their personality; the value of such objects is assessed in symbolic rather than economic terms. Given our present knowledge of the Middle Ages, both with regard to the realities of everyday life and the prevailing mentality, it seems that the identification of people with their private possessions must have been much stronger than today.

127 Karol Koranyi also found an expression close to this ancient maxim in, among other places, a fourteenth-century compilation of Parisian law: "Les bies ensuyvent le corps quanta aux meubles"; idem, "Podstawy średniowiecznego prawa spadkowego," Pamiętnik Historyczno-Prawny 9, no. 2 (1930), 39.

128 This seemingly anachronistic division is still visible in the dispositions of testators and in disputes regarding wills brought before the courts in Krakow in the late fifteenth century. For example, in her will of 1476 , Catherine glezerynne ordered that tutors of her choice should donate all the property she left to the work of charity, with the exception of the gerade, which should be given to those to who are entitled to it; LT, fol. 114 (1476). The durability of the division into female and male objects is also evidenced by critical remarks made by Bartłomiej Groicki about the gerade in the mid-sixteenth century: "I know very well that we should be wary of correcting or contaminating laws, which were established through the hard work of many wise men, and they undoubtedly had merit and proper grounds for the age when they were written. But when other centuries have other customs - alias vita alios mores postulate - than scholars of the law, if such need arises or there is a good use for it, it is not a futile task, as they say, that many laws shall change, many of them shall be undone as well. Therefore, there is a new interpretation of conflicting laws concerning the gerade, due to the troubles and tensions it brings about among friends, to such injustice that a more distant person is to take, in spite of there being a closer one and to the endless excesses of the female garments"; idem, Tytuty prawa majdeburskiego, Warszawa 1954, 13. 
The description above is intended to shed light on the reasoning behind a certain kind of donation in which testators bequeathed their personal belongings, such as belts, coats, spoons, pitchers and the like, to the Church. In this way, these objects acquired a religious, mystical and, to some extent, 'magical' significance, i.e. they became liturgical items (usually chalices and chasubles) used to celebrate Holy Mass. ${ }^{129}$ Such objects were not important just because they were used during the celebration of Holy Mass, they were considered 'holy' themselves because of their direct participation in the Sacrament of the Eucharist. In the fourteenth and fifteenth centuries, as lay people became more knowledgeable about religion and the cult of the Eucharist became more widespread, their desire to participate more fully in the sacrament grew. ${ }^{130}$ In folk religion, ${ }^{131}$ the forms of worship accepted by the Church intertwined and overlapped with older, pre-Christian ceremonies and rituals and attitudes toward the sacred. ${ }^{132}$ Drawing on numerous testimonies, Johan

129 " [...] men most commonly gave vestments, or money to buy vestments, whereas women gave their own clothing such as dresses and kerchiefs, and household linens like sheets and tablecloths - items which held personal meaning but which were also part of their public identity as virtuous, diligent and modest homemakers"; Nicola A. Lowe, "Women's Devotional Bequests of Textiles in the Late Medieval English Parish Church, c. 1350-1550," Gender \& History, 22 (2010), 408.

130 "The doctrine of Christ's authentic presence in the Eucharist, disseminated among the faithful by the Church and questioned only by the adepts of heretical movements, made it possible to see it as a symbol of worship, but also a the object itself, the very body of Christ within the host. The attitude of devotion promoted by the clergy among believers was based on the natural tendency of people to see a deity present on earth. Therefore, looking at the host became a spiritual need of the followers of Christianity and an important, commonly observed devotional practice. This need in believers, testified to in the sources from the thirteenth century, was reinforced by the development of the Eucharistic cult and lasted until the late pre-Reformation period. It was manifested in the pursuit of frequent and long (as possible) viewing of the host raised during the Mass by the priest. [...] In addition to believing in the mysterious, magical power of the host, looking at it was considered a manifestation of due piety"; Stanisław Bylina, Religijność późnego średniowiecza, 54

131 Folk religiousness was defined by Stanisław Bylina as follows: "It includes phenomena involving a substrate of archaic beliefs, manifested even just in traditional attitudes, often with a magical motivation"; ibidem, 9 .

132 In describing the first stage of the Christianization of the Polish lands in the late thirteenth century, Jerzy Dowiat pointed to the importance of magical thinking for the creation of a kind of syncretic model of Christianity in the lands inhabited by Slavs: "Christians who came to Poland, including clergy [...] also introduced Christian magic: treating objects of liturgical cult as endowed with magical power, and also referring to liturgical texts as a kind of magical spells"; idem, "Pogląd na świat," in Kultura Polski średniowiecznej X-XIII w., ed. Jerzy Dowiat (Warszawa: Państwowy Inst. Wydawn., 1985), 174. 
Huizinga demonstrated that in the late Middle Ages the phrase 'to see God'133 simply referred to the elevation of the host. As such, it straddled the fine line between reverence for the miracle of Holy Communion and profanity. While such an approach to religion prevailed among the uneducated masses, "such traditional attitudes towards religion, expressed in various kinds of rituals and gestures, were also shared by educated members of society, as we learn in theological treatises from the fourteenth and the fifteenth centuries." ${ }^{134}$

The first fourteenth-century bequest to mention the personal belongings of the testator was drafted by the mine administrator Paszek. In 1358, Paszek donated three coats (one made of marten fur, a brown coat with a lining, and a blue coat) and one tunic to clergymen with whom he was friendly. ${ }^{135}$ These were undoubtedly expensive gifts, but given the testator's vast wealth, their true value was commemorative. On the one hand, the gifts indicated that Paszek knew the clergymen well; on the other, such a valuable gift demanded some form of reciprocation (praying for Paszek's soul) and would be hard to forget. ${ }^{136}$ Paszek also stated in his will that two silver belts should be given to brother Gregory to make a chalice and two silver cruets. ${ }^{137}$ Likewise, Barbara, widow of Martin Nimpczer, stated in her will that her belt and spoons should be used to make a gilded chalice for St Mary's Church. ${ }^{138}$ Nicholas Topler left two 'big spoons' and a man's belt to St. Bernardine's Church, stating that they should be used to make a chalice and a paten (a type of small plate used in the Eucharist). ${ }^{139}$ Many other testators made special dispositions, stating that the silver personal items they possessed should be made into liturgical chalices. ${ }^{140}$ For example, Anna, wife of the innkeeper Peter Wolski, bequeathed all of

\footnotetext{
133 Johan Huizinga, The Autumn of the Middle Ages, 178.

134 Stanisław Bylina, Religijność późnego średniowiecza, 10.

135 "Item Palium cum pellibus Marderinis demandauit fratri Bartkoni. Item aliud palium bruneticum cum Subductiua fratri gregorio. Item Palium flaueum cum tunica domino Boguslao plebano in Ossek"; NKiRMK, no. 1692, 1693.

136 Józef Burszta, Spoteczeństwo daru i dar w spoteczeństwie, in Do, ut des - dar, pochówek, tradycja (Funeralia Lednickie, 7), ed. Wojciech Dzieduszycki, Jacek Wrzesiński (Poznan: SNAP. Oddział, 2005), 17-24.

"Item duos Cingulos argenteos fecit dare fratri Gregorio pro Calice aut pro duabus ampullis"; SCAB., no. 1692, 1693 (1358).

138 "Item noch meynem tode ap meyne gortil und leffil blebin, so sullen meyne vormunde doraus lossen eynen guten kelch machen und den lossen vorgolden ud sullen den entwerten czu unsir liben frawen am Ringe gelegen"; LT, fol. 27 (1452).

"Item so gebe ich czu sinte Bernhardino dy grosten II silberen leffil und eynen mannes gortil das man eyn kelich und eyne patene machen”; LT, fol. 99-100 (1470).

140 For example, Peter, an attorney, recommended: "Item zo hot her gegeben und bescheiden das silbir das her czu Johanne Tendirneudir legin hot czu eyme kelche czu machen und
} 
her movable and immovable property to her husband, except for seven silver spoons and buttons (nodis), which were to be made into a chalice that was "as big as possible." The chalice was to be donated to St. Bernadine's Church and the monastery there. ${ }^{141}$

Based on the bequest of Dorothy, wife of Nicholas Kestener, that her valuables be melted down and made into a chalice. ${ }^{142} \mathrm{~A}$ similar bequest was made from the foundation of Claire, the widow of John Hobschbeck, who donated the proceeds from the sale of her meat stall for the purchase of a chalice, chasuble and other liturgical items. ${ }^{143}$ In turn, Martin Junge paid for a chalice and a chasuble to commemorate his late wife. ${ }^{144} \mathrm{We}$ can assume that the testators mentioned above also wished to turn their valuables into liturgical objects that would have direct contact with the sacred. ${ }^{145}$ On the one hand, such a gift was another means of commemorating the testator, as their personal belongings an 'extension' of themselves - were used to celebrate Holy Mass. ${ }^{146}$ On the

czu sinte Marcus in das Clostir czu geben," cons. 428, fol. 125 (1419); Margaret Puskinne: "Ouch gebe ich Magistro Johanni czwene slechte cappe silbrin und I cleyn Capchin und IIII leffil czu eyme kelche," SCAB. 5, fol. 114 (1425); Peter Eichler: "Item was von silbrin gerete ist do sal man eyner kelch aws machen," SCAB. 5, fol. 130 (1426); and: LT, fol. $5^{2}$ (1458), 56 (1458), 68 (1460), 109-110 (1475), 143-144 (1487), 149-150 (1491).

141 "Primo Petro marito suo legitimo legavit effectualiter omnia bona sua mobilia et immobilia debita et utensilia universa nulla penitus exclusis cum plena proprietate faciendi et dimittendi exceptis solum septem cocleariis argenteis et nodis exquibus calix quanto melius fieri potest pro monasterio et ecclesia sancti Bernhardini disponi debet”; LT, fol. 36 $(1456)$.

142 "[...] omnia iocalia ipsius argentea debent fabricari ad calicem et calix ad Ecclesiam in Pilgeramisdorf assignari"; coNs. 427, fol. 74 (1396).

143 "Item quartale macelli, qua vendita [s] debent comparari calix et ornatus cum aliis pertinenciis ad missam"; SCAB., no. 414 (1369).

144 "[...] auch beuele ich XVI marg czu sente Stephan czu der kirchen, adir, wirt man bawen eine kirche hy vor der stat, so sal man dy XVI marg dorczu gehen, wenne alzo vil geldis brochte myne frawe czu mir, dy ich vor der hatte, ouch bit ich, das man von der cronen vnde von den schellin, dy do bey sint, sal man I kelch czugen vnd I gancz messegewant dorczu in dy selbe kirche"; sCAB., no. 1816 (1393).

145 "Among these objects, the most important were those paraments that came into direct contact with the sacred during transubstantiation, as well as chasubles, amices, albs, maniples, and other elements of liturgical clothing, which were also becoming key liturgical objects visible throughout the Mass"; Oliński, Fundacje mieszczańskie w miastach pruskich, 81 .

146 "The psychology of magical thinking lists numerous examples of how the sense of Self of a primitive human did not refer to the model of an integral person. This human saw him or herself rather as a set of independent parts or dispositions. For this reason, the Self also included personal objects and even family goods."; Magdalena Kowalska, Psychologiczna (prze)moc wzajemności, in Do, ut des, 43. 
other hand, the desire to be in the direct presence of the sacred can be interpreted as a form of 'magical thinking, a believe in contagious power of the sacred..$^{147}$

As evidenced by the will of the goldsmith Nicholas Brenner, these valuable personal belongings were not simply sold to pay for liturgical items. Brenner was a master of his craft, and counted among his clients members of the uppermost social elite, including the voivode of Krakow, John Tenczyński; the castellan of Tarnów (Tharnische herre); members of Krakow patrician families; and the canon of Krakow, John Długosz. ${ }^{148}$ Because Brenner's will was made on his deathbed, he listed numerous orders he had not yet fulfilled. These records clearly show that silver items, such as cups or goblets, were given to the goldsmith to be melted down and used as raw material for liturgical items. ${ }^{149}$ The donated items, retaining their purity, were thus turned by the goldsmith into sacred objects, containing, in a symbolic way, the figure of the testator. For example, gilded chalices donated by Matthias Opoczka, John Odów and the municipal notary Christopher Rebentcz to St. Mary's Church bore inscriptions clearly stating the names of the donors. The first stated: HIC CALIX COMPARATUS EST PER DOMINUM MATHIAM OPOCZKO PRO ECCLESIA BEATE VIRGINIS; the second: HUNC CALICEM COMPARAVIT IOHANNES ODOW; and the third: HUNC CALICEM HONORABILIS CHRISTOFORUS NOTARIUS HUIUS CIVITATIS COMPARAVIT. ${ }^{150}$

Some testators, in turn, donated expensive fabrics for chasubles. In fulfilment of the provisions of John Stolle's will, Sweidniczer donated expensive damask fabric to St. Mary's Church for a chasuble to be worn by the priest who celebrated Mass at the altar funded by Stolle. Similarly, Margaret Leipnigerinne donated expensive fabric for a chasuble for 'her altar' at a church

147 Stanisław Bylina, Religijność późnego średniowiecza, $53-58$.

148 LT, fol. 83-84 (1464).

149 Among the interesting entries was one concerning the commission of a new monstrance for the Curch of St. Catherine in Kazimierz, Krakow: "Item czu der Monstrancia czu sinte Katherina czu Kazmer habe ich entpfangen newnczen marg solber und vonfte halbe scot. So habe ich abir entpfangen czwen alde kelche dy haben beide gewegin vir marg und sebinczen scot solber ungebrant. Abir entpfangen czwu marg solber und sechs scot gebrant. Dornoch habe ich entpfangen drey marg solber minus sechs scot gebrant solber. Abir habe ich entpfangen von eynem fusse und eynem koppe ungebrant das wegit fonftehalbe marg und sechstehalbe scot solber. Item so habe ich entpfangen of dy erbit von der selben Monstranczia virczen gulden"; LT, fol. 83-84 (1464).

150 Najdawniejsze inwentarze skarbca kościoła N.P. Maryi w Krakowie z XV wieku, ed. Franciszek Piekosiński, Krakow 1889 (reprint in "Sprawozdania Komisji do Badań Historii Sztuki w Polsce” 4, no. 2 (1889), 64-77). Elżbieta Piwowarczyk, Dzieje Kościoła Mariackiego (XIII-XVI w.) (Krakow: Wydaw. Naukowe PAT, 2000), 175-177. 
in Bytom. She also donated 12 grivna in silver from her personal silverware to make three chalices for, respectively, St. Bernardine's Church, the monastery in Lechnica, and 'her altar' at the church in Bytom. ${ }^{151}$ In his 1492 will, the wealthy tailor Jarosz stated that his expensive damask bedspread (tectura lectus de kamcho) should be made into a chasuble for the parish church in his hometown of Zator. ${ }^{152}$

A rare but quite telling bequest was made by the affluent merchant John Reichil. Among his many pious bequests was one for his weapons and armour, including a cuirass, a helmet and visor, and a horse, to be given to the Benedictine monastery of the Holy Cross at Łysa Góra. ${ }^{153}$ We do not know how the Krakow merchant came into possession of this military equipment or why he donated it to the Benedictine monks, but we can assume based on the nature of the gift, that its economic value was not as important as its symbolic value as a kind of votive gift to the sanctuary. ${ }^{154}$ It is very possible that the testator made such a gift because he wished to be buried in the monastery. ${ }^{155}$ In Polish lands, such bequests were usually made by knights, for whom armour symbolized their function, role and privileged social position. ${ }^{156}$ Armour, which was rarely possessed by burghers, constituted part of the hergewet. John Reichil

\footnotetext{
$151 \quad$ LT, fol. 37 (1456).

$15^{2}$ LT, fol. $15^{1-152 .}$
}

153 "Item so gebe ich den hern czu dem heiligen Crewcze of dem Berge alle meyne Harnosch, panczir, lapke, heubchen etc und eyn pferd"; sСAв. 6, fol. 196-197 (1440).

154 He renewed this disposal two years later in his will of 1442: "und seynen harnisch beschit her czu dem heyligen Crewcze"; sCAB. 6, fol. 256.

155 "Devoting armour pro remedio animae was supposedly widespread especially in places where the custom of placing weapons and other objects in graves was abandoned only under the influence of Christianity [...]. Despite Christianization, however, the old belief sometimes manifested itself in acts of last will. By donating certain objects to a church institute, the testator wanted the objects that served him during his lifetime, very often armour in particular, to be placed in his resting place after his death, où je serai sevelie, ubi corpus meus sepelietur, ubi sepultus fuero, quia ibi expectabit resurrectionem iustorum. Sometimes this also included objects that the deceased had come into contact with, and therefore were considered his own"; Karol Koranyi, Podstawy średniowiecznego prawa spadkowego, 91-92.

156 "The custom of donating armour to the church where the principal was buried is also established in some places in Poland. There are also cases in which the family considered it their duty to donate a part of the deceased's military equipment, such as a horse, to the church. Admittedly, in Polish land law armour did not have a separate legal status among movables as it had in Saxon law. However, there is no denying the possibility that the latter influenced land law in this respect [...]. We can see here the influence of the Church, likely modelled on the practices it developed in other countries, incorporating the aforementioned old religious beliefs that the deceased should be buried close to objects they used during their lifetime."; ibidem. 
could thus have made his bequest to the monastery because he lacked male heirs. A potential lack of heirs motivated Catherine, widow of the goldsmith George, to make in her will numerous pious bequests (she also donated two silver cups for chalices to Krakow churches) to be carried out in the event of the death of her only child. ${ }^{157}$ The tailor Jarosz decided, in turn, that if one of his sons became a priest, two silver cups (picarios) should be made into a chalice and paten. ${ }^{158}$

Testators had different reasons for donating valuable personal belongings, silverware and fabrics to the Church to be turned into liturgical items. The examples listed above generally represent only part of the pious bequests made by these testators. They can be interpreted as yet another means of securing one's salvation, as votive offerings made to gain God's favour (do ut $e s) .{ }^{159}$ The decision to turn silver items into chalices, patens and cruets may have been motivated by a scarcity of raw silver 'on the market.' Another factor influencing these dispositions was the specific function played by a burgher's jewellery, silverware and other valuables, which were not only purchased as ostentatious displays of wealth, but also as investments that could be liquidated (sold or melted) if necessary. It is thus difficult to say for certain whether such donations of liturgical items were typical pious bequests or whether they reflected a deeper, unexpressed intention, one reflecting some mix of religious and magical beliefs. Such a mix has been suggested by Aleksandra Witkowska in relation to the votive practices of pilgrims in the Krakovian 'sacred places' i.e. churches storing relics of saints (loca sacra):

Votive practices that treat a saint as a party to a contract are undoubtedly very close to magical practices. The element of magic is especially evident in the custom of offering gifts, which symbolically represent the

157 LT, fol. 142-143 (1484).

158 "Item si aliquis dictorum puerorum videlicet Stanislaum vel Jacobum aliqui sacerdotibus conmisit sibi duos argenteos picarios suorum pro bono calice cum patena dandis"; LT, fol. $15^{1-15^{2}}$ (1492).

159 "In the culture of gestures and imagery developed in the late Middle Ages, it seems that the votive gesture - propitiatory, thankful, or, somehow coercing the saint into making a miraculous intervention - served primarily as a visible sign of faith in the power of a 'contract' based on to the principle do ut des implicit in the vow. A person approaching the ad loca sacra saw their request had been answered or wanted it to be so, and brought a gift symbolizing the relationship established between them and the saint. The contract was made through such a sacrificial gesture, which was suited to a rather primitive religious imagination with a strong element of magical thinking, determinedly seeking the goodwill in the sacred expressed through some kind of transactional exchange of mutual favours";AleksandraWitkowska, Kulty patnicze, 213-214; Marcel Mauss, The Gift. 
donor or the object of his petition for divine intervention. The moment when one appeals for help, motivated undoubtedly by religious convictions, also involves magical thinking. The votive offering symbolising the petition transfers its reality to the symbol or image. Placing it within the nearest sphere of the sacred causes, it is believed, the blessing of the reality that the gift symbolizes. ${ }^{160}$

Due to the popularity of this type of bequest, we have evidence of a confirmed practice and custom found among Krakovian burghers. Due to its specific nature, this custom confirms the hypothesis of a link between these donations and the characteristic need for as direct as possible an experience of the sacred, which was centred around the altar. ${ }^{161}$

\section{The Familial Dimension of Piety}

Another dimension of burgher religiosity was centred on the family. ${ }^{162}$ We can assume that, as with other spheres of burgher community life, religious life also had a syncretic character, insofar as traditional family rituals were saturated with religious symbolism. ${ }^{163}$ Such rituals were an important element in

160 AleksandraWitkowska, Kulty pątnicze, 215.

161 "Apart from the above-mentioned function of the language of communication, votive practices were also considered a chance to prolong the physical presence of a pilgrim at a place of worship. From the point of view of religious anthropology, votive offerings are an important testimony to a special form of participation within the sacred circle. A votive offering is once again used as a substitute. Left in the place of worship, it is equivalent to the physical presence of the vower. The bonds of their contact with the saint are strengthened by this gesture and continue to be maintained"; ibidem, 217-218. A similar intention can be seen in the desire to bury the body of the deceased in a church as close to the main altar as possible: "The choicest and most expensive location was the choir, near the altar, where the Mass was said, in the place where the priest recited the Confiteor. (The reader will recall that the underlying reason for burial apud ecclesiam was the sacrifice of the Mass, rather than the protection of the saints)."; Philippe Ariès, The Hour of Our Death, trans. Helen Weaver (New York: Viking, 1981), 79.

162 Marek Słoń, Religijność komunalna w Europie środkowej późnego średniowiecza, in Zbožnost středověku, ed. Martin Nodl, Krzysztof Bracha, Jan Hrdina, Paweł Kras (Praha: Filosofia, 2007) (Colloquia mediaevalia Pragensia, 6), 21.

163 "Medieval religious practice, whether Christian, Muslim, or Jewish, was intimately connected to family life. Mothers were responsible for basic religious education at virtually all social levels, and personal piety conducted within a domestic environment was a fundamental component of religious practice"; Linda E. Mitchell, Family Life in the Middle Ages (Westport: Greenwood Press, 2007), 171. 
family life, greatly influencing the nature and strength of the bonds within this 'basic social unit.' Unfortunately, because so few sources say anything about everyday religious life in the home, this area (like many other aspects of everyday life) will remain for us terra incognita.

Another problem we face is the question of the scope of our research and its representativity given the diversity that existed in medieval urban society. In Chapter Three on the family and marriage, an analysis of various bequests allowed us to distinguish two different models of the burgher family. The first, the nuclear family - consisting of parents, children and, sometimes, household servants - was characteristic of the poor and middle class. Family life revolved around the family home, the artisan's workshop, or stall (they were sometimes located in the same building). A characteristic feature of this model was the existence of close emotional bonds existing between the spouses, and a marked distance from (and in some cases even an aversion to) more distant relatives. It can be assumed that this was due to the living situation of many burghers, for whom the success of the individual (often an immigrant) depended primarily on his or her hard work, the support of his spouse and children, and only to a lesser extent, the help of more distant, often poor relatives, who were also potential heirs.

In the second model, that of the extended family, the so-called patrician model characteristic of the city's elite, the bonds between spouses were significantly less marked by a mutual concern for each other's security. The wife of a patrician was not only entitled to a significant dower, she might also receive significant inheritances from members of her family. She was thus relatively independent of her husband, and, it can be assumed, her marriage was more of a 'contract between families' than an expression of true emotions. ${ }^{164}$ On the other hand, in the extended family model, mutual bonds connected not only the immediate family, but also adult siblings, nephews, nieces, and the in-law family. This is not surprising, as the success of a merchant's career depended not only on his luck, knowledge and abilities, but also on his social capital, including his family contacts.

The functioning of two such very different family models in the medieval city undoubtedly influenced the religious practices of their members. In this area, the activity of the city's social elite was particularly visible - they engaged in devotional activities not only 'privately, i.e. directed inward, but also demonstrated their piety 'publicly' to the entire city. As evidenced by the analysed

164 Barbara A. Hanawalt, The Wealth of Wives. Women, Law, and Economy in Late Medieval London (Oxford: Oxford University Press, 2007), 70-78. 
sources, an important role was also played here by the culture of the written word, in which patricians participated to the greatest extent. The factors mentioned above were largely responsible for the fact that the family dimension of religiosity visible in the sources is reflective mainly of the wealthiest representatives of urban society rather than of the population of medieval Krakow as a whole. ${ }^{165}$

What we know about religious practices within the family is based on manifestations of these practices outside the family home. The most striking 'external' manifestation of urban religiosity was donations made by Krakow's elite to various churches and religious institutions. Since at least the mid-fourteenth century, affluent Krakovian burghers had been involved in the building and furnishing of St. Mary's Church, and, to a lesser degree, other churches. ${ }^{166}$ The information contained in wills provides many examples of commemorative bequests that were meant to ensure the salvation of the testator, as well as of his deceased relatives and ancestors. This was true of a generous foundation from Nicholas Wierzynek (Wirzing) the elder to help finance the building of a new presbytery at St. Mary's Church. He was commemorated with a plaque which informed the public who the donor was: FUNDATOR CHORI ISTIUS A. D. 1360 FRANCISCI FESTO DIE SOLIS, DAPIFER WIRZING OBIIT. ${ }^{167}$ Nicholas Wierzynek the younger and three other Krakovian burghers, Herman Krancz, Arnold Welker and Nicholas Trutil, also wished to fund private altars at St. Mary's Church. We know this because they wrote to Pope Urban $\mathrm{V}$ seeking his permission. ${ }^{168}$ Since few sources from this period have survived, it is unclear whether these pious donations were made inter vivos or as testamentary bequests. The former seems to be the case, however, as indicated by information pertaining to councillor Herman Krancz's will from 1380 telling us that Krancz had made a bequest to found a new altar, which had been formally

165 Although the influence of the elites on the culture of the city as a whole was undeniable, it is certainly not possible to project the presented practices directly into the wider context of the municipality.

166 "The ambition that St. Mary's Church, the parish church for the largest and wealthiest part of the city population, would become an urban cathedral with a status similar to the Wawel Cathedral is visible already in the fifteenth century. These efforts were reflected not only in the altar service, but also in the special patronage of the Krakow burghers, who were working towards its ennoblement through numerous foundations"; Elżbieta Piwowarczyk, Dzieje, 123.

167 "According to church records, on the southern wall on the small choir, shielded from view by stalls, was a plaque with the inscription: Fundator chori istius, A.D. 136o Franciscifesto die solis, Dapifer Wirzing obiit"; Ambroży Grabowski, Krakow i jego okolice, Krakow 1866, 362. 
approved fifteen years earlier. ${ }^{169}$ The new altar, dedicated to Corpus Christi, with the altarage of St. Longinus, was placed in the church choir (a cornu Ewangelii Majoris Altari) and equipped with the necessary items, purchased with revenue from a farm Krancz had bought in the village of Prądnik. ${ }^{170}$ A donation made by councillor Nicholas Edel in 1369, however, was not referred to as a will or testamentary bequest in Krakow's oldest municipal book. In the presence of councillors from the municipal council, Edel left his stall, together with two grivna in annual rent, to the Dominicans. In return, the friars were to say a daily Mass for the salvation of Edel's "ancestors and descendants" in his chapel. ${ }^{171}$ However, Edel left further instructions for the councillors, who were to pay the Dominicans rent twice a year and ensure that the friars held up their end of the agreement. Otherwise, the municipal council had the right to spend the money on food for the sick or other acts of charity to ensure the salvation of Edel and his family. ${ }^{172}$ As evidenced by his 1393 will, Gotfrid Fattinante of Genoa funded two altars to ensure the salvation of his soul (in salutare anime sue remedium). ${ }^{13}$ The first altar was erected at St. Mary's Church for the glory

169 KDWac., vol. 2, no. $3 \circ 9$.

170 "S. Longini 1-ministerij Fundationis Hermani Krancz Civis Cracoviensis. Erectum hoc ministerium Anno D. 1380 d. 13 Januarij ex censu anno f. 80 in Allodio in villa Prąmnik 2000 Reemptionalis, Possesionis Conventus Tynecensis Ordinis S-i Benedicti"; cited in Elżbieta Piwowarczyk, Dzieje, 131.

171 "Honorabilis vir Nicolaus Edelingi nobis conconsul, dum simul in pleno sederemus consilio, nobis Magnarum precura instancia intimitis suplicauit, vt assumpta nobis nomine Ciuitatis nostre Instita sua in acie in Medio institarum sita et Duas Marcas polonicales currentis monetę, nos aut qui pro tempore fuerint Consules Ciuitatis constituti, de pretorio singulis annis elemosine perpetue ipsis Religiosis viris fratribus predicatoribus Conuentus dicte nostre Ciuitatis daremus. Cuius elemosine virtute ijdem fratres predicatores ipsorum exigente deuocione ad unam missam cottidie in Capella eiusdem Nicolai Edelingi celebrandam in ipsius predecessorum omnium et posterorum suorum animarum remedium salutare vitro se exhibuerunt firmiter astringendo, prout in eorum literis desuper confectis luculencius continetur"; NKiRMK, no. 1705.

172 This provision from 1369 already indicates the role of the municipal council as an institution that supervised, mediated and supervised the religious life of the Krakow burghers. Initially, this care most likely primarily concerned certain families from urban elite circles.

"Primo vero in salutare anime sue remedium Cameram suam pannorum circa cameram Pauli Nutricis et sex marcas census annui et terragij, quem super fundo domus Nicolai Beidner in platea sutorum site, habere dignoscitur, pro altari in honorem sanctorum Anthonij confessoris et alme virginis Dorothee ac martyris ad taxam sedecim marcarum et valorem in ecclesia parochiali sanete Marie Virginis semper gloriose in Cracouia erecturo siue erigendo, feliciter construeturo siue construendo, cuius collacio, presentacio, prouisio seu queuis alia disposicio ad Consules Ciuitatis Cracouiensis nunc et pro tempore existentes, perpetuo pertinere debeat, de quo altari prouidit ad presens domino Petro capellano et notario suo, domum vero suam lapideam in acie circuli circa 
of St. Anthony, Blessed Dorothy and martyrs (sanctorum Anthonii confessoris et alme virginis Dorothee ac martyris). The second altar, dedicated to the same figures, was erected at All Saints Church. Apart from his grandson, whom he mentioned in his will, Gotfrid Fattinante did not have any other close relatives. ${ }^{174}$ However, the will of councillor Michael de Czirla, from 1435, explicitly stated that he wished to ensure his own salvation as well as the salvation of his children and ancestors (pro anime mee et filii mei ac progenitorum meorum suffragio salutary). ${ }^{175}$ This testator funded an altar at St. Mary's Church, "for the glory of God and St. Mary Mother of God" (ad laudem Dei et eius genitricis honorem) for this purpose. ${ }^{176} \mathrm{We}$ can assume that if there was no explicit information in the will about why the testator decided to found new chapels, altars or perpetual altarages, the motivation behind the gift was to commemorate the testators and ensure the salvation of their souls, as well as the salvation of their ancestors, children and grandchildren. In this way, these most generous

Powsuange sitam, valido viro domino Spitkoni Palatino ac Capitaneo Cracouiensi, vt per ipsum ac electos presentis testamenti executores infrascriptos alicui ciui vendi debeat, et pro huiusmodi pecunia census sedecim marcarum perpetuus comparari, et de eodem censu sedecim marcarum altare eciam sanctorum Anthonij Confessoris et beate Dorothee Virginis in ecclesia parrochiali Sanctorum Omnium in ciuitate Cracouiensi eciam de taxa sedecim marcarum erigi et construi, cuius collacio seu queuis alia disposicio ipsi domino Spitkoni ac suis posteris legitimisque successoribus perpetuis debet pertinere temporibus, dedit, contulit ac perpetuo assignauit, quod eciam altare domino lohanni presbytero domus sue et medico assignauit"; KDWac., vol. 2, no. 396, 182-185.

174 It is likely that he was related or associated with the Krakow governor Spytko, known as "Palatinus ac Capitaneus Cracouiensis," to whom he handed over the right of presentment to one of the altars; cf. Józef Garbacik, "Gotfrid Fattinante," in PSB, vol. 6 (Krakow: Polska Akademia Nauk, Polska Akademia Umiejętności, 1948), 377-378.

175 "Primo mencionem faciens capelle, quam in cimiterio beate Marie Virginis contiguam ostio meridionali eiusdem ecclesie citeriori edificandam ipse iam antea disposuit, cuius et iam sunt posita fundamenta, volo inquit, ut compleatur opus illud usque ad plenam ipsius capelle consumacionem, scilicet iuxta eam formam et modum, secundum quod condixi et convencionem feci cum muratore. Et in eadem capella, cum perfecta fuerit, edificari debet altare et consecrari, in quo iugis fiat missarum celebracio ad laudem Dei et eius genitricis honorem, pro anime mee et filii mei ac progenitorum meorum suffragio salutari. Namque ad eiusdem altaris dotacionem, do, lego et assigno $13 \mathrm{mr}$. census annui et perpetui communis pecunie polonicalis, quorum censuum $8 \mathrm{mr}$. et 16 scoti sunt in et super teloneo Cracoviensi, quas hucusque annuatim habui et percepi, relique $5 \mathrm{mr}$. eiusmodi census comparari debent de illis $400 \mathrm{mr}$. communis pecunie polonicalis, quas michi providus Claus Kezinger, civis Cracoviensis, tenetur, inscriptas in villam suam Trzebinia, ita ut sint 13mr. pro rectore seu altarista dicti altaris et 16 scoti reliqui pro luminibus ad usum eiusdem altaris per ipsum altaristam perpetue convertendi”; cons. 428, fol. 344.

176 It was to be located in the chapel of St. Mary's Church, which was then under construction, 'by the southern door.' 
pious foundations, which were meant to bring to mind similar bequests made by noble, secular and spiritual elites, were a testament to the importance and assumed glory of new Krakow burgher families. This trend was so influential that expensive foundations were established by both members of long-standing patrician families in Krakow, such as the Wierzyneks (Wirzings), Langs and Morsztyns (Mornsteyn, Mornstin), and the 'nouveau riche,' who entered the elite circles of Krakow through marriage. By the end of the fourteenth century, burghers had financed eleven new altars at St. Mary's Church, which remained Krakow's most important religious building. As evidenced by a list made by John Długosz in Liber beneficiorum, in the latter half of the fifteenth century this number had increased to thirty altars. One, two, or even three Masses were celebrated before each altar daily. ${ }^{177}$ By the end of the fifteenth century, two new side altars had been erected. Thanks to the joint efforts of the parishioners and numerous testators, a new main altar was built for the church - the famous St. Mary's Altar by Veit Stoss. ${ }^{178}$ As Elżbieta Piwowarczyk aptly noticed:

At the end of the fifteenth century, chapels began to occupy a special place in St. Mary's Church. With time, those possessing them were seen as a kind of city's nobility. The families of the founders would often pray at the chapel's altars, and in many cases attended Mass more often in the chapel than at the main altar... Special stalls were later installed for them. In around the mid-fourteenth century, these family chapels began to be separated from the main nave with bars placed in the arcades, which resulted in their relative isolation from the physical space of the temple. ${ }^{179}$

Krakovian testators did not, however, limit their bequests to St. Mary's Church, the parish church of many burghers. Similar foundations were established at other churches in the city and throughout the Krakow urban agglomeration, ${ }^{180}$ as well as at churches in other towns, usually the testators' hometowns. ${ }^{181}$ Testators naturally tended to identify most closely with their own parish, which not only formed a sort of community of prayer, but also comprised a community

\footnotetext{
177 Elżbieta Piwowarczyk, Dzieje..., 164-166.

178 Marjan Friedberg, "Ołtarz krakowski Wita Stwosza. Studium archiwalne," Przeglad Zachodni 8, no. 7/8 (1952), 673-706.

179 Elżbieta Piwowarczyk, Dzieje, 161-162.

180 E.g. the foundation of an altar in All Saints' Church by Gotfried Fattinante; KDWac., vol. 2, no. 396.

181 E.g. the foundation of an altar in St. Anne's Church by the councillor Nicholas Zarogowski, LT, 129-131 (1482), or an altar owned by Margaret Leipnigerinne in a church in Bytom and mentioned in her will, LT, fol. 37 (1456).
} 
in the social sense. The participation of a wealthy burgher family in religious rites was likewise usually centred around a particular church, generally the family's parish church, in part due to the increasing popularity of burying lay people on the church grounds (if possible, in the family chapel or the vicinity of an altar funded by the family). ${ }^{182}$ However, this privilege and distinction was reserved almost exclusively for the most affluent burghers. According to a fifteenth-century register of people buried in St. Mary's Church (Registrum sepultorum in ecclesia beate Virginis in Cracovia), almost all of them were tied to the city's elite. ${ }^{183}$ Among the thirty-five people listed in the register, four were members of the Krakow municipal council, ${ }^{184}$ and two were aldermen, ${ }^{185}$ while others included the spouses, children and grandchildren of municipal councillors. ${ }^{186}$ Their being buried in such a prestigious location was often not the result of having made such prior arrangements, but rather due to pious bequests made by their husbands, fathers and grandparents on their behalf. 187

182 As Philippe Ariès noted: "[In wills] the church was almost always chosen for family reasons, so that one could be buried either beside one's parents or, more often, beside one's spouse and children. The practice became widespread in the fifteenth century, and it clearly expresses the rise of a feeling that transcended death. Indeed, it may have been the moment of death that brought this feeling to full consciousness. [...] The family prevailed over the military kinship that had united the Knights of the Round Table in their cemeteries; their real family had been their fellow warriors. It accommodated itself, on the other hand, to the trade brotherhoods, because spouse and children were buried together in the chapel of the confraternity.; idem, The Hour of Our Death, $75^{-76}$.

183 A list of people preserved on a separate sheet of paper, probably written in mid-fifteenth century, is certainly not complete, since it ends in 'etc.': "Langmichil metquartus; Petir Ffetttir; Iohannis Sweydniczers due filie; Herman Wolff; Paulus Homan; Martinus Leypniger; Stano Rockinberg; Morsteynynne; Pavel Bemynne; Stano Plesner cum uxore; De.... preterita; Orientynne; Kaltherberginne; Paulus Fetter; Hedwigis uxor Maly; Petrus filius Fettir; Hannus Wynkonis filia; Claus Kesling filia; Crokerynne; Stano apotecarius; Agne Cromerynne; Langniclas filia; Petri Hirsberg filius cum filia; Bernharth vom Brige; Bernhardus notarius civitatis; Sweydniczer filius; Ffornal; Petri Grazer filius; Beeczsky filia; Thewdernewderynne; Mater domini Nicolaj Gortner; Bochnerynne; Neorzynne rotmannene etc."; Najdawniejsze inwentarze, $76-77$.

184 "Langmichil, Paulus Homan, Petir Ffetttir, Bernharth vom Brige"; ibidem.

185 "Herman Wolff, Paulus Fetter"; ibidem.

186 "Iohannis Sweydniczers due filie, Martinus Leypniger, Morsteynynne, Pavel Bemynne, Orientynne, Kaltherberginne, Petrus filius Fettir, Hannus Wynkonis filia, Claus Kesling filia, Langniclas filia, Petri Hirsberg filius cum filia, Sweydniczer filius, Petri Grazer filius, Beeczsky filia, Bochnerynne, Neorzynne rotmannene"; ibidem.

187 There are examples of women also being involved in foundation activities in Krakow and other cities; cf. Oliński, Fundacje i legaty religijne kobiet świeckich w wielkich miastach pruskich, in Kobieta irodzina w średniowieczu ina progu czasów nowożytnych, ed. Zenon Hubert Nowak, Andrzej Radzimiński (Toruń: Uniwersytet Mikołaja Kopernika, 1998), 143-16o. 
For example, in his 1440 will, councillor Peter Hirszberg made a bequest of ten grivna of rent to pay for a ministerium at the altar of St. Agnes he had funded at St. Mary's Church. ${ }^{188}$ Other testators, including Paul Homan, ${ }^{189}$ Michael Lang (Langmichel) ${ }^{190}$ and Stanisław Morsztyn ${ }^{191}$ also funded ministeria at St. Mary's Church. Other members of the patriciate listed in the register had their own 'private' chapels, altars or prebends at St. Mary's Church and other churches in Krakow. ${ }^{192}$ Burials of patricians on the grounds of a church, with their tombstones embedded in the church floor, was another manifestation of the ongoing 'privatization' of the physical space inside churches. ${ }^{193}$

The family dimension of urban religiosity also manifested itself in the paternalistic relation of some patricians to their servants. For example, after

188 "Ich Peter Hirsberg der Cromer mache meyn testament und schickunge meyns leczten willens also. Meyn haus in deme ich wone in der Schugasse an der ecke, czu nest bey Stane Gortelers hause gelegen, das bescheide ich und gebe czu gotis dinste, und czu eyme ewigen zelegerethe in sulchir weyze, daz meyne vormunde hy noch geschreben, das haws noch meyme tode vorkewffen sullen noch der Stat recht, und sullen umb das geld czinse kewffen czeen mark, adir wy vil man mag, und dy czinse vorreichen und geben czu dem Elter sinte Agniten, den ich gebawt und angericht habein der pfarkirchen unser frawen hy czu Cracow, in eyne ewige belenunge desselben Eltirs, und denselben Eltir vorleyeich und gebe, czum irsten den irben pristir hern Mathis Peyser der denselben Elter iczunt belist und vorwest von meyner Schickunge, und noch seyme tode so gebe ich das loen desselben eltirs meyme Swoger Peter Olslager dem Cromen und noch im seynen erben und elichen nochkomelingen czu ewigen tagen, also mit namen, daz sy dy czinse als obene czu dem Eltir schicken sullen, und dy nummer lossen abegeen durch keyne ablozunge adir wedirkowfft in keyner weyze"; sCAB. 6, fol. 205.

189 "Czu dem erstin gebe ich IIC mrg breyter groschin czu eynen Altare czu unser liben frawen wo man daz dirkennen wirt, wo ist notdorfft ist"; SCAB. 5, fol. 79 (1423).

190 "Primo mencionem faciens capelle, quam in cimiterio beate Marie Virginis contiguam ostio meridionali eiusdem ecclesie citeriori edificandam ipse iam antea disposuit, cuius et iam sunt posita fundamenta, volo inquit, ut compleatur opus illud usque ad plenam ipsius capelle consumacionem, scilicet iuxta eam formam et modum, secundum quod condixi et convencionem feci cum muratore. Et in eadem capella, cum perfecta fuerit, edificari debet altare et consecrari, in quo iugis fiat missarum celebracio ad laudem Dei et eius genitricis honorem, pro anime mee et filii mei ac progenitorum meorum suffragio salutari”; cons. 428, fol. 344 (1435); cf. Sławomira Pańków, "Lang (de Czirla)," in PSB, vol. 16 (Wrocław-Warszawa-Krakow: Polska Akademia Umiejętności, 1971), 481-482.

191 SCAB. 7, fol. 82 (1450); cf. Maria Michalewicz, "Stanisław Morsztyn," in PSB, vol. 21, Wrocław-Warszawa-Krakow 1976, 821-822.

192 E.g. John Sweidniczer, Paul Homan, Paul Beme, Peter Graser or Martin Beczky.

193 Information about the tombstones of the alderman Stanisław Czipser, the councillors John Schultis, Nicholas Kreidler, John Sebenwirt and probably also three councillors beheaded for the murder of Andrew Tęczyński (Stanisław Leymitter, Kuncze Lang and Jarosz Szarlej), as well as, perhaps, John Szyling and Wojciech Malarz, have survived to this day; Elżbieta Piwowarczyk, Dzieje, 162-164; Marcin Starzyński, Krakowska rada, 92-94. 
the death of his servant Martin, councillor Nicholas Dambraw acted as executor of his last will, ensuring that Martin's distant relatives from the outskirts of Wrocław received his belongings. ${ }^{194}$ John, an aged servant of Anna Willuschinne, asked her in his will to donate his wages to opera pietatis. ${ }^{195}$ We also know that some wealthy burghers joined religious brotherhoods together with both members of their immediate family and their servants. ${ }^{196}$ Wealthy patricians looked after their servants' interests even after their death. As evidenced by the 'register of the dead' maintained by the Brotherhood of the Blessed Virgin Mary, some burghers paid for Masses and obituaries for their deceased servants. In one such case, the name of Nicholas Dambraw's servant Martin appears in the register shortly before Dambraw's own name. ${ }^{197}$ The register also lists the names of many servants employed by the municipal council, ${ }^{198}$ various brotherhoods ${ }^{199}$ and patrician families in Krakow. ${ }^{200}$

Some testamentary bequests also show us the importance of family tombs and the family rituals that revolved around them. Testators generally made bequests in order to make donations to churches in which they either wished to be buried or in which their ancestors or late spouses were laid to rest. For example, Margaret Glezerinne, widow of councillor Nicholas Glezer, left 30 grivna to the Dominican order to pay for a perpetual Mass for her soul. She also donated two chasubles and a chalice to the Dominican church in Krakow,

194 "Martinus czirnyk de suburbio civitatis Wratislaviensis nomine tutorio sue conthoralis legitime ac suorum puerorum recepit decem marcas gr. prg. num. pol. a provido Nicolao Dambraw nostri collega consilii, executore testamenti Martini pie memorie sui famuli, de omnibus bonis ac universis rebus ipsum Czirnyk, uxorem eius pueros que ipsorum, quomodolicet concernere valentibus prefatum Dambrow dimisit liberum penitus et solutum"; cons. 427, fol. 69 (1396).

195 "Johannes famulus senex Anne Willischynne constituit eandem dominam suam ad precium suum deservitum, quod is apud eam habet in opera pietatis, secundum quod ipsa salubrious fore cognoverit convertendum, exclusitque omnes suos consangwineos et propinquos"; SCAB. 6, fol. 190 (1439).

196 "At this point we should note that employees would customarily join the organization together with their employers, as confirmed by the register of the Kleparz Brotherhood. In 1503, Anna Mandzina and her deceased relative were entered in the afore-mentioned book. The next entry concerns Valentine, referred to as the servus of Anna Mandzina. In 1504, John Szczyrba and his wife joined the brotherhood, followed by Catherine, uxor fabri Jacobi qui apud Szczyrba moratur et laborat."; Hanna Zaremska, Bractwa, 162. Józef Mitkowski, "Księga zmarłych bractwa kościoła Panny Marii w Krakowie (wiek XIVXVIII)," Studia Historyczne 11, no. 1 (1968), 83.

198 Cf. "Vor Andris stat dyner"; ibidem, 82.

199 Cf. "Vor Cuncze eyn dyner der brueder"; ibidem, 83.

200 Cf. "Vor Maczko Stane Wirsings dyner"; ibidem, 82. 
asking to be buried in the church alongside her husband. ${ }^{201}$ Ursula, widow of the municipal notary Eustace, wanted to be buried in St. Mary's Church next to the tomb of her mother, which was located between the altar of the Blessed Virgin Mary and the altar of St. Catherine. ${ }^{202}$ Councillor Hippolyte Spilberger also asked in his will to be buried in St. Mary's Church, including a bequest of 20 grivna to the church. ${ }^{203}$ The noblewoman Anna Obulczowa, daughter of councillor George Orient, donated all of her clothing (including an expensive coat listed in the will), jewellery, and household items for her burial and 'works of mercy.' She asked to be buried in her family's chapel, the so-called Weynrich's chapel, ${ }^{204}$ which contained an altar dedicated to the Annunciation of the Blessed Virgin Mary. ${ }^{205}$ In her 1458 will, Margaret Pferdinne set aside $5^{\circ}$ grivna for her funeral (stating that the rest of the estate should be used to buy clothing for the poor) and instructed that her body should be buried wrapped in a black shroud. ${ }^{206}$ As evidenced by the will of alderman and councillor Paul Ber, family tombs helped maintain strong bonds between an individual and the parish church of their former home. In 1467, Ber instructed the executors of his will to donate to St. Nicholas's Church in Głogów, among other things, "the

201 "Item czu den paulern do meyne elden leggen und do ich leggen wil sal man XXX marg werunge geben czu eyner ewigen messe, und czwu kasiln dy ich habe lossen machen und eynen kelch"; cons. 428, fol. 243 (1428).

202 "Item man zal nich begrabinn do meyne mutter leyt tczwenschinn Unser liben frawen alter und sante Katherine alter"; LT, fol. 148-149 (1489).

203 "Item zu unser liben frawen kirchin am Ringe gibt her zu gebewde XX mrc und dorumme sal hero uch in der selbin kirchin begrabin werdin"; LT, fol. 95 (1469). In 1501, the widow of Nicholas Zalcz and Stanisław Czipser and the wife of John Łowicz gave only 10 florins for burial in the St. Mary's Church: "Sepultura vero elegit in ecclesia Beate Marie Virginis in circulo pro qua dat decem florenum"; LT, fol. 166 (1501).

204 "Item omnes vestes, schubas, clenodia et utensilia domus commisit domino Stanislao vendendas et cum pecunia honestam sepulturam et pro salute anime sue disponendas... Item elegit sibi sepulturam in capella sua Weynrich etc."; LT, fol. 147 (1489).

205 The altar was originally founded in the last will and testament from 1449 of Theodoric Weinrich, a Krakow presbyter. In 1462, the altar ministry was endowed again by Weynrich's relative, Duchess Barbara of Racibórz, mother of the future Duchess Machna of Zator and Anna Obulczowa, mentioned here.; KDMK, vol. 3, no. 432 (1449); Elżbieta Piwowarczyk, Dzieje, 146; Katalog Archiwum Aktów Dawnych Miasta Krakowa, vol. 1: Dyplomy pergaminowe (Krakow: Archiwum Aktów Dawnych Miasta Krakowa, 1907), 102, 165.

206 "Item von den obrigen fonczig marken sal man mir dy beygraft ausrichtin, und was do obir bleben lewten czu cleydern. Item ouch von den genanten fonfczig marken sal man In alle Clostir lossen lesen dreyssig selemessin vor meyne sele. Item so hab ich eynen grossen selbereynen kop aus dem selben sollen meyne vormonden lossen machen czwene kellich und das machlon sal man nehmen von den vonfczig marken und das beczalen und dy selben czwene kellich sollen meyne vormonden gabin noch irem dirkentnis [...]. Item ich begere das man mich undir swarczen gewande losse czu grabe tragen dorbey vir korczen"; LT, fol. 52. 
better of two silk (kamcha) chasubles he had ordered"207 and a new missal so "that these two things would help preserve the memory and ensure the salvation of his parents and relatives buried there." ${ }^{208}$ We also learn from the will that at the time his sister was still living in Głogów. This will demonstrates that, even as a burgher of Krakow, who had lived in the city for many years, Paul Ber did not break his ties with his old parish church. The ties between Ber and St. Nicholas's Church were also influenced by his family history: Ber's ancestors were buried in that church.

\section{3}

\section{The Corporate Dimension of Burghers' Piety}

Among the features defining an urban community (which clearly differed from a traditional agrarian community) was the diversity of the people comprising it and the complexity of its social structure. While in the countryside a relatively small and homogeneous local community was bound together by the local parish church, an urban community featured more diverse social relations, suited to the needs of the burghers who lived there. As urban populations grew, the inhabitants of cities looked beyond their local parish or commune for ways to satisfy their natural need for belonging and their desire to participate in social life. A unique 'urban culture' developed, comprised of smaller, more homogenous (and initially informal) burgher communities. Urban municipalities developed their own internal social structures, including city offices, councils and bench courts, as well as professional organizations such as guilds and corporations, and religious organizations such as brotherhoods and, to some degree, communities of unmarried or widowed lay religious women, known as beguinages. ${ }^{209}$ These developments reflected both a natural human need for social belonging suited to the modern relations of production and social relations taking shape at that time, and the adoption (and adaptation to local conditions) of German municipal organizational forms. The role of the Church was significant in this respect because it exerted a tremendous influence on culture, eschatology and social relations. ${ }^{210}$ An equally important role was played by German settlers who immigrated to Krakow from Silesia. They

\footnotetext{
207 "[...] eyne kamiche kasel dy beste undir czween dy ich gereyt habe"; scAB. 8, fol. 270-271.

208 " [...] das man dy czwestucke alle tage notczen sal zu eyme gedechtnisse und troste meyner elden und frunden zelen, der leythnam dorselbist rasten"; sCAB. 8, fol. 270-271.

209 Jerzy Wyrozumski, Korporacje zawodowe i religijne w średniowiecznym Krakowie, in idem, Cracovia mediaevalis, ed. Marcin Starzyński (Krakow: Avalon, 2010), 213-221.

210 Hanna Pátková, Bractwa w czeskich miastach katolickich i utrakwistycznych, in Ecclesia et civitas, 219.
} 
first helped Krakow receive its charter, and then essentially took control of the city's power structures. ${ }^{211}$ Two common features of all these more or less formalised communities were their tendency to function as corporations and - in spite of theoretically being open to everyone - the practice of admitting into their ranks only members of specific burgher social groups. ${ }^{212}$ Despite their many differences, the authorities, guilds and brotherhoods in a city functioned as both secular and religious organizations (distinguishing between the two was impossible in the Middle Ages). While the purposes of these communities differed, none of them could have come into existence or performed their function without rituals to 'sanctify' the role they played in society. This created a great deal of historiographical confusion in the description and classification of urban communities by historians, who attempted to demarcate the boundaries between the spheres of the sacrum and profanum in the medieval city. Meanwhile, the burgher wills (like the statutes and legal privileges of these organizations) demonstrate that the sacred and the profane were closely interconnected. ${ }^{213}$ Councillors and aldermen acted in the religious sphere not only as representatives and guardians of burgher interests (as will be discussed further on), but also of those of their own corporation. ${ }^{214}$ Craftsmen

211 Feliks Kiryk. Migracje z miast matopolskich do elity wtadzy Krakowa w XIV-XVI wieku, in Elita władzy miasta Krakowa, 181-19o; Jerzy Wyrozumski, Lokacja 1257 roku na tle rozwoju krakowskiego zespotu osadniczego, in idem, Cracovia mediaevalis, 181-204.

212 Women, especially wives and widows of guild craftsmen, can also be considered members of these corporations; cf. Janusz Tandecki, Kobieta $w$ rzemiośle miast pruskich na przetomie średniowiecza i czasów nowożytnych, in Kobieta i rodzina, 161-174.

213 "The corporate character of the social life of medieval towns was reflected in the corporate style of devotion at that time. When the dominance of the councillors and their circles in the municipality is considered, the question of their relationship with the parish church arises. A list of the guilds that were forming then should be aligned with a map of the churches in which their chapels were placed. The emergence of journeymen's associations is accompanied by the creation of corresponding centres of worship, distinct from those serving the city's guilds in general. When the council established a beggars' confraternity, it looked for a spiritual guardian and a church for them. The same is true of ethnic groups, each of which strived for a separate area to satisfy their devotional needs"; Hanna Zaremska, Bractwa, 37.

214 The numerous manifestations of this activity include the creation of the council's chapel in the town hall or benches in St. Mary's Church dedicated to councillors and aldermans. "In the Middle Ages, there were no permanent church benches filling the entire interior of the church. Sitting at Mass was a privilege of the few. Not only possessing decorative stalls, but even the fact of sitting in the church was a demonstration of power. Initially, representatives of the clergy, rulers and church patrons had the right to sit on benches during Mass; by the end of the Middle Ages they were joined by patricians and members of fraternities and guilds;"; Katarzyna Cieślak, Między Rzymem, Wittenbergą a Genewa. Sztuka Gdańska jako miasta podzielonego wyznaniowo (Wrocław: Fundacja na Rzecz 
who were members of guilds and brotherhoods cared not only about their own businesses and material well-being, but also attended the funerals of their deceased 'brothers' and prayed for their souls. ${ }^{215} \mathrm{After}$ all, as one fifteenth-century preacher stated, "you are considered damned, if no one lights a candle for you." ${ }^{216}$ It seems, therefore, that in the medieval city every community was, ${ }^{217}$ technically speaking, a Christian community and acting on its behalf was thus considered a pious act.

Although few lists of the members of brotherhoods in late-medieval Krakow have survived, ${ }^{218}$ we can examine the relations between burghers and brotherhoods by analysing testamentary bequests. Forty people (out of 457 testators) specifically made bequests to guilds or brotherhoods in their wills, but we should assume that such organizations were often the beneficiaries of wills in which the spouse, family members or other executors of the will were authorized by the testator to donate money to opera pietatis. It should be emphasized that Krakow wills also demonstrate that medieval burghers did not distinguish between religious brotherhoods and professional organizations. Both were usually referred to by the Latin fraternitas, or the German bruderschaft, ${ }^{219}$ indicating that they were seen as both secular and religious communities:

Nauki Polskiej, 200o), 296; cf. Michał Rożek, Przewodnik po zabytkach Krakowa, 2nd ed. (Krakow: Wydawnictwo waM, 2010), 144; Krzysztof J. Czyżewski, "Siądź mi po boku prawym.' O zasiadaniu w kościele słów kilka," in Mecenat artystyczny a oblicze miasta. Materiaty LVI Ogólnopolskiej Sesji Naukowej Stowarzyszenia Historyków Sztuki, Krakow 8-10 XI 2007, ed. Dariusz Nowacki (Krakow: Stowarzyszenie Historyków Sztuki. Oddział Krakowski, 2008), $57-76$.

215 "Collective forms of fraternal piety are primarily preoccupied with matters of the next life. While examining efforts to obtain indulgences, organise proper burial ceremonies, and the power of a supplicatory procession, it is difficult to distinguish between concern for one's eternal life and striving to comply with God's commandments in one's life on Earth. The eschatological imagination is closely intertwined with the concern for the everyday dimension of the worldly present."; Hanna Zaremska, Bractwa, 137; eadem, “Żywi wobec zmarłych. Brackie i cechowe pogrzeby w Krakowie w XIV-pierwszej połowie XVI w." KH, vol. 81, 1974, no. 4, 733-749.

216 Aleksander Brückner, "Kazania i pieśni: szkice literackie i obyczajowe," in Literatura religijna w Polsce średniowiecznej, vol. 1 (Warszawa: Gebethner i Wolff, 1902), 72.

217 It seems that as a consequence of this juxtaposition, the individual was ideologically degraded to a sinful being, and a community of such sinners made sacred for being endowed with the will of God and His mission.

218 Only lists from the Krakow Brotherhood of the Blessed Virgin Mary from St. Mary's Church from 1481 and 1484 have survived since the Middle Ages.; Hanna Zaremska, Bractwa, 67-75.

E.g. SСAB., 2168 (1395); SCAB. 5, fol. 72 (1423). 
These guilds, city council corporations, and shooting confraternities, from the point of view of the clergy, were liturgical congregations that required the services of priests to provide them with spiritual and religious guidance. The shared practice of regularly attending Mass together and the centering of social life around devotional activities created more or less permanent spiritual bonds between their members. ${ }^{220}$

In 1447, the elders of the Brotherhood of Millers at the Church of the Holy Trinity (seniores fraternitatis molendinatorum ad sanctam Trinitatem) appeared before the municipal council as witnesses to the will of the late Catherine, a weaver (textrix). They testified that she had died at the home of John Kuchler, ${ }^{221}$ and left all her movables to Jacob, the church prior, to be spent on charitable acts and to pay for her funeral, and John Kuchler, to repay him for his kindness towards her. ${ }^{222}$ It should be noted here that in the Middle Ages there was no millers' guild in Krakow, ${ }^{223}$ and thus this (rather enigmatic) brotherhood affiliated with the Dominican Church must have acted as a 'substitute' congregation. ${ }^{224}$

The $145^{8}$ will of Agnes Lossinne is also interesting. She appointed as executors of her will a journeyman from the Tailors' Guild, Peter Bogener, ${ }^{225}$ who owed her 50 florins, and two master craftsmen from the Cutlers' Guild, John Neisser and John Haze. ${ }^{226}$ Lossinne disinherited all of her relatives, and instructed the executors of her will to donate her assets as an act of charity to Krakow's hospitals and leper houses. The only specific dispositions found in the will are instructions concerning the money that Peter Bogener owed her:

\footnotetext{
220 Hanna Zaremska, Bractwa, 41.

221 In 1418 and 1424, John Kuchler (Luchler) was listed as the master of the bakers' guild on the list of senior guild members, and in 1444 his son, who shared his name and surname, was probably an elder of the carpenter's guild.; cons. 428, fol. 108, 207, 470 (1418, 1424, 1444).

"Pyotr, Woyteg Roszani halfarze, Domenig murars et Micolay seniores fraternitatis molendinatorum ad sanctam Trinitatem recognoverint quod Katherina textrix bone memorie in domo Johannis Kuchler defuncta ad huc dum in humanis viveret omnia sua bona mobilia que habuit eisdem commisit distribuit pro amore dei et salute anime sue ad Ecclesiam sancte Trinitatis et etiam pro sepulture religiosumque fratri Jacobum priori eiusdem Ecclesie, Johannem Kuchler ab omnibus si ingruerint infestacionibus intercedere et evintere racione bonorum et iterum per eum datorum etc. que fuerit ipsius Katherine etc."; CONS. 428, fol. 5 oo. A millers' guild is not mentioned in any surviving medieval list of older guilds in Krakow.

224 E.g. CONS. 428, fol. 497 (1447), 511 (1448), 523, 524 (1449).

225 He acted as a master of the tailor's guild in 1459; CONS. 429, fol. 226.

226 Neisser held this position in $145^{8}$ and Haze in the following year; cons. 429, fol. 196, 227 $(1458,1459)$.
} 
ten florins were to be donated for the fabrica of St. Bernardine's Church and another ten florins used to buy a shroud (leichtuche) for the Cutlers' Guild.227 There are no surviving sources indicating that the Cutlers' Guild was associated with any specific church in Krakow; 228 however, the structure of the bequest suggests that it may have been affiliated with the newly founded observant Franciscan monastery in 1453 . The funding of the shroud, however, indicates that the Guild undoubtedly organized funerals, the importance of which is emphasised in the statutes of all of Krakow's guilds and brotherhoods. 229

The third professional corporation mentioned in the analysed Krakow wills was the Brotherhood of Goldsmiths (goltsmede bruderschaft). In 1460, Margaret Grobniginne instructed the executors of her will to sell half of her house and use the money to finance her pious bequests. In contrast to Catherine and Agnes Lossinne, Margaret chose to make numerous small bequests (from five to ten florins each) to different churches (St. Mary's Church and St. Bernardine's Church), hospitals, leper houses and the poor. In her last donation, she left a mere one grivna to the Brotherhood of Goldsmiths. Here again, we do not know whether this Brotherhood was affiliated with any specific church in Krakow. However, given the prestige of the profession, the wealth of the testatrix, and the bequest she made to St. Mary's Church, it is probable that the Krakovian goldsmiths took part in religious services there. The bequest of one grivna made to the Brotherhood was probably meant to cover the costs of the funeral, in which the members of the Brotherhood were to take part. ${ }^{230}$

227 "Czum irsten gebe ich czeen gulden czu dem gebewde der kirchen sinte Bernhardin. Item czeen gulden czu eynen leichtuche der Bruderschaft des hanthwergis der Messirsmede alhy czu Cracow und dese czwenczig gulden obgenant sollen genomen werden von der schult der funfczig gulden ungerisch, dy mir Petir Bogener obgenant schuldig ist”; LT, fol. 50 (1458).

228 Hanna Zaremska did not mention cutlers in her list of connections between the guilds of Krakow and city churches; eadem, Bractwa, 40.

229 "The funeral ceremony in fraternal circles was one of the most prominent forms of commemorating the dead. Participation in the final farewell for a companion became a duty, which stemmed to a large extent from the conviction that the ceremony was important for the future fate of the deceased. Participation in funerals was an inherent obligation of brothers and sisters in religious associations from the fourteenth to the sixteenth century."; ibidem, 140.

230 "The second group among the members of the brotherhood [of Blessed Virgin Mary J.W.] in 1481 were craftsmen. There were 32 of them, including 15 senior guild members. The most numerous groups were butchers, goldsmiths and furriers. The corporation associated all senior representatives of the professional circles of that time."; ibidem, 68-70; Jerzy Pietrusiński, Ztotnicy krakowscy, 55-77. 
Most bequests, however, were made to brotherhoods with no clear professional affiliations. The majority of bequests was made to two of the most prestigious corporations, namely the Brotherhood of the Blessed Virgin Mary (eleven bequests) and the Brotherhood of St. Barbara, named after St. Barbara's Cemetery Chapel (fifteen bequests). Both fraternities were affiliated with Krakow's main parish - St. Mary's Church. The Brotherhood of the Blessed Virgin Mary was probably the oldest and the most prestigious confraternity in Krakow. It was established no later than the early $1370{ }^{231}{ }^{231}$ From its inception, it played a special role in Krakow, bringing together representatives of the municipal authorities and affluent burghers. We find the names of some of those affiliated with this corporation in the so-called Book of the Dead, ${ }^{232}$ and from a list of brothers and sisters from the time of its reactivation in $1481{ }^{233}$ In her analysis of the most credible list of the Brotherhood's members, Hanna Zaremska observed that during that period the corporation's membership comprised the city's elite, which was closely connected through professional and family ties: "The brotherhood affiliated Germans, many of whom were newly-arrived immigrants, whose representatives began to gain dominance over 'old' families such as the Wierzyneks or the Gleywiczs in the latter half of the fifteenth century." 234 With many members of Krakow's richest burgher families among its ranks, the organization was not surprisingly generously endowed by them. For example, in her 1440 will, Salomea, wealthy widow of goldsmith Nicholas Brenner, donated 200 florins from the sale of part of her house located on the main market square to fund an altarage at the altar dedicated to the "Omnipotentis Dei et Visitationis B.M.V."235 This altar was located in the chapel of the Brotherhood of the Blessed Virgin Mary, near the choir by the main entrance to the church, between its two towers. ${ }^{236}$ She passed on her patronage of this altarage to the Brotherhood after her death.

231 Because the first people entered in the obituary of the Brotherhood of Blessed Virgin Mary had died.; cf. Józef Mitkowski, Księga zmartych, 77; Hanna Zaremska, Bractwa, 48.

232 Józef Mitkowski, Księga zmartych, 71-95.

233 Biblioteka Jagiellońska, ms 2365, Reformacio fraternitatis S. Marie in circulo Cracoviensi facta est anno incarnacionis Domini 1481, 10-13.

234 Hanna Zaremska, Bractwa, 70.

235 Elżbieta Piwowarczyk, Dzieje, 134-135.

236 "Et pro eisdem ducentis florenis ungaricalibus in auro, census quantos et ubi tute petent amat, in dotacionem altaris ipsius fraternitatis quod est in capella ipsorum super ingressum ipsius ecclesie inter duas turres, eiusque altaris iuspaternatus et presentandi reservo michi ad tempora vite mee, post mortem vero meam idem Juspaternatus et presentandi do fraternitati predicte iure perpetuo possidendum"; SCAB. 6, fol. 215. 
We can deduce from surviving sources that the Brotherhood of St. Barbara was an equally prestigious organization. It was founded by the Bishop of Krakow Peter Wysz in 1404. Although its establishment may have initially resulted from a rivalry between the bishop and the Krakow municipal council, ${ }^{237}$ in the following decades, its members and benefactors, like those of its Marian counterpart, included affluent Krakovian patricians. This specific aspect of the brotherhood, which it shared with St. Mary's Church, was emphasized by the name by which it was referred to in a diploma received by Zbigniew Oleśnicki in 1444: The Brotherhood of Merchants (Fraternitas Mercatorum). ${ }^{238}$

The third most important brotherhood in Krakow in terms of the number of testamentary bequests made to it was the brotherhood affiliated with the so-called Hungarian chapel at the mendicant church of St. Francis (which received eight bequests). The name of the chapel and some written sources indicate a link between the corporation, and the chapel with which it was affiliated, with Krakovian burghers of Hungarian origin. ${ }^{239}$ However, the wealthy testators who made bequests to it do not appear to have had any ties with Hungary; all of them were, in fact, affluent representatives of the handicrafts in Krakow. ${ }^{240}$

Somewhat fewer bequests were made to the Brotherhood of the Holy Spirit, which was affiliated with the church and the hospital of the same name. The brotherhood must have had strong ties to the hospital, because testators usually made bequests to the 'brotherhood in the hospital' (czard bruderschaft in dem Spetil) or to the brotherhood in the hospital of the Holy Spirit (dy bruderschaft czum Spital alhy czu Krakow czu der Heiligen Geiste). ${ }^{241}$ As many as four out of six individuals who made bequests to this confraternity also made bequests to other brotherhoods. We can thus assume that such bequests were seen as donations to the city hospital.

Two bequests of a similar nature were made to the oldest and the most important confraternity in the city of Kazimierz, the Brotherhood of Corpus Christi, based in the church of the same name. Founded some time before

\footnotetext{
237 Hanna Zaremska, Bractwa, $76-77$.

238 Ibidem, 77.

239 The Hungarian chapel served Hungarian students of the University of Krakow. In 1507, King Zygmunt granted them eight barrels of salt a year, on condition that on holidays they would sing Gaude Dei genitrix; cited in ibidem, 83 .

240 John Lode, LT, fol. 10 (1439); Peter Eichler, a tailor, LT, fol. 12 (1448); Catherine Michelinne, Cons. 429, fol. 54 (1452); Wincenty Czanser, a fustian weaver, LT, fol. 47 (1457); Simon Noldener, a bowyer, LT, fol. 55 (1458); Margaret Prewszinne, a bowyer, LT, fol. 59-6o (1459); Stanisław Kulek, a stallholder, LT, fol. 93 (1468); Łazarz a cutler, LT, fol. 109-110 (1475). 
the mid-fourteenth century, it had strong ties with the Kazimierz municipal council, indicating that it, like the Brotherhood of the Blessed Virgin Mary in Krakow, most likely attracted members of the social elite. ${ }^{242}$ John Zindram and the cutler Łazarz both made testamentary bequests to the Brotherhood of Corpus Christi, while at the same time also making bequests to, respectively, the confraternity of the Blessed Virgin Mary ${ }^{243}$ and the brotherhood connected with the so-called Hungarian chapel. ${ }^{244}$ It is possible that these burghers belonged to both confraternities, but the Brotherhood of Corpus Christi in Kazimierz was probably an additional affiliation to the two Krakow brotherhoods.

Other fraternities, two in Krakow (the Brotherhood of the Eleven Thousand Virgins at St. Stephen's Church and the Brotherhood of St. Sophia at St. Mark's Church), one in Kazimierz (the Brotherhood of St. Catherine) and one in the Krakow's suburb (the Brotherhood of St. Nicholas), were each mentioned in the analysed wills once. In 1457, Elizabeth, daughter of the late Philip, a tailor, made a bequest of two grivna to the brotherhood at St. Stephen's Church and of one grivna to the brotherhood at St. Mark's Church. ${ }^{245}$ Apart from these modest bequests, there is little more that can be said about these rather unimportant congregations until the late fifteenth century. ${ }^{246}$ The confraternity of St. Catherine at the church of the Augustinians in Kazimierz and the brotherhood of St. Nicholas at the suburban parish church were probably more important. In 1464, before going to war against the Turks, the bricklayer Martin made a bequest of five grivna to both St. Nicholas's Church and the Polish brotherhood in this church (fraternitati polonorum in ecclesia predicta). ${ }^{247}$ It is worth noting that, since its founding in the early fifteenth century, the confraternity of St. Catherine at the church of the Augustinians had been referred to as the Polish Brotherhood (Fraternitas Polonorum). ${ }^{248}$ In 1459 , the wealthy widow Anna Florianinne made a bequest of ten florins to this brotherhood. However, because this bequest was only one of many similar donations made by this testatrix, we cannot determine the nature of the relation between her and the brotherhood. ${ }^{249}$ Nevertheless, the fact that these religious fraternities were referred

\footnotetext{
242 This is evidenced by a document from 1347 which granted indulgences to brotherhood members; Hanna Zaremska, Bractwa, 85-86.

243 LT, fol. 9 (1446).

244 LT, fol. 109-110 (1475).

245 SCAB. 7 , fol. 312.

246 Hanna Zaremska, Bractwa, 79-82.

247 LT, s 82.

248 Hanna Zaremska, Bractwa, 88.

249 LT, fol. $64-65$.
} 
to as either Polish or German indicates that there existed religious, social and linguistic divisions in medieval Krakow.

Krakovian testators made bequests to two other fraternities outside of the Krakow agglomeration. One was in Krosno and the other "in Prussia." In the first, the above-mentioned Anna Florianinne made a bequest of ten florins to the brotherhood at the parish church in Krosno. ${ }^{250}$ In the second, in addition to a bequest of ten florins to the brotherhood at the Krakow hospital of Holy Spirit, Margaret Leipnigerinne made a bequest of ten florins to the brotherhood at the Carthusian monastery "in Prussia ... to which she belonged."251 These donations appear to demonstrate that the testatrices maintained strong ties with religious communities in their former hometowns.

A characteristic feature of the analysed donations to lay religious fraternities was their relatively modest size. The vast majority of bequests did not exceed a couple of grivna and were one of many bequests made by the testator. For example, in addition to his bequest of five grivna to the Brotherhood of the Blessed Virgin Mary at St. Mary's Church "to maintain the service" (czu stewir des dinstis), the court plenipotentiary Lawrence made analogous bequests to the Franciscans (for the fabrica of the church), to lepers near Krakow (at St. Valentine's church and hospital) to purchase foodstuffs, and to lepers near Kazimierz (at St. Leonard's church and hospital) "for construction work and other needs." ${ }^{252}$ In his 1435 will, the pharmacist Paul Tanneman made a bequest of five grivna to the Brotherhood of Saint Barbara. He also made similar bequests to the Church of Corpus Christi in Kazimierz, to the poor at two hospitals (of the Holy Spirit and of St. Hedwig), and to other poor men and women. ${ }^{253}$ More generous bequests were made by John Frolich in his 1395 will. If he, his wife, and his son died, Frolich's estate was to be divided into two parts, with one part to be donated to the Brotherhood of the Blessed Virgin Mary and the other to the poor and the sick (pauperibus infirmis). ${ }^{254}$ In turn, the stallholder Margaret Jostinne donated her gerade to her confessor, an altarist at the altar of Saint

250 Ibidem.

251 "Den karthewsern in Prewssen czu den ich bruderschaft habe czen gulden"; LT, fol. 36 (1456).

252 SCAB. 6, fol. $213(1440)$.

253 KLK6, 113.

254 “[... si autem pueri morirentur, extunc pars ipsorum omnium ad ipsam dominam devolvatur, prefatis vero personis, tam domina, quam pueris omnibus sublatis de medio, debet medietas bonorum residuancium ad fraternitatem ecclesie sancte Marie et reliqua medietas pauperibus infirmis dari tam per fratres, quam per procuratores eius, Nicolaum Morrensteyn et Petrum Weidochse: reservat dominium"; sCAB., no. 2168. 
Anna at St. Mary's Church. Should he die, "because we are all mortal,"255 the gerade was to be divided into four parts and donated to St. Mary's Church, the Brotherhood of the Blessed Virgin Mary at the same church, the altarists' home, and the brotherhood at the hospital (of the Holy Spirit). ${ }^{256}$

It should be emphasized that nine people made simultaneous bequests to two fraternities, without favouring either one - both fraternities were given the same sum of money. The councillor John Sweidniczer made two bequests of ten grivna each to both the Brotherhood of the Blessed Virgin Mary and to the Brotherhood of St. Barbara. He also made identical bequests to the lepers at the hospitals of St. Leonard and St. Valentine, to St. Mary's Church, to the Dominicans, to the Franciscans, to St. Catherine's Church, and to the church of Corpus Christi. The bequests to the fraternities were thus one of many other identical bequests made to religious institutions located in the Krakow agglomeration. ${ }^{257}$ While this may indicate that John Sweidniczer was a member of all of these organizations, it may also demonstrate a characteristic desire among medieval burghers to make bequests to as many institutions and people as possible. The possibility also exists that both tendencies are reflected in this case. Nevertheless, these multiple bequests show that being a member of a brotherhood constituted an important aspect of the social and religious life of some medieval burghers.

It can also be assumed that the bequests made to brotherhoods were often a form of payment for funeral ceremonies and memorial Masses in the brotherhood's chapel, for the salvation of a testator's soul:

The fact that responsibility for the organisation of funerals rested in the hands of lay fraternities appears to shed new light on the role they played in the social life of the local community. The corporation's memory of

255 "Geschege is ader als wir alle totlich seyn, daz derselbe her Niclas ee vorschide wenn ich"; sCAB. 6, fol. 59 (1433).

256 "Item allis das ich lossen werde boben dy gerade, das bescheyde ich meyme beichtvater hern Niclas, elthern das elters sinte Anne czu Unser Liben Frawen, mit befelunge meyner zele, als ich Im getrawe. Geschege is ader als wir alle totlich seyn, daz derselbe her Niclas ee vorschide wenn ich, so sullen meyne vormunde das geben in dy werk der barmherczikeyt, als eyn teyl czu unser liben frawen czur kirchen, und eyn teyl czur bruderschaft deselbist, eyn teyl den Elterhern doselbist czum hawse in dy gemeynem eyn teyl czur bruderschaft in dem Spetil, und czur heiligen befelen"; sСАв. 6, fol. 59 (1433).

257 The testator also assessed the value of the institutions, because he bequeath 20 grivna for the construction of St. Bernard's Church as well as to the sick both in the hospital of the Holy Spirit and St. Hedwig, and 5 grivna each to St. Mark's Church, 'the New Convent' (the Carmelites) and to St. Ann.; LT, fol. 39-45 (1457). 
their deceased brother was not limited to ceremonially sending them off on a solemn journey. The chapels of guilds and fraternities essentially served as a place for holding funeral services and praying for souls in Purgatory. Masses for the dead (Missa pro defunctis) were also periodically held in them, during which long lists of the names of those who had died in recent years were read out loud. This was an expression of their efforts to ensure that their prayers were properly 'addressed' with the names of the individuals whom those in the terrestrial communitas wished to support in their efforts to attain eternal peace. ${ }^{258}$

This is evidenced by the will made by Wilhelm Megirszheimer of the Nurembergian town of Thunkilspul (Dinkelsbühl) in $1482 .{ }^{259}$ Each of his pious bequests, regardless of place and purpose, were for ten Rhenish florins. He donated ten Rhenish florins for the new altarpiece (hohen altar) on which Veit Stoss was working, and for the fabrica (zum gebaude) of St. Mary's Church, his final resting place. Megirszheimer also made bequests of ten florins to the Franciscans and to the Carmelites (for a new church and for Gregorian Masses for the release of his soul). In addition, Megirszheimer also made a bequest of ten florins to the Brotherhood of St. Barbara, on condition that its members "provide all the things needed for his funeral, including a shroud and other things in accordance with the custom of the brotherhood."260 He also stated that "all funeral costs should be properly accounted for."261 Moreover, he left his brother 400 florins, instructing him to pay for a perpetual Mass for his soul in his home town of Thunkilspul. Wilhelm Megirszheimer appointed three executors of his will - they were to ensure that all his instructions regarding bequests made to Krakow churches and institutions were carried out properly. This will is very interesting because of the testator's background. A merchant by profession, he came to Krakow on a business trip. A sudden illness or some other unforeseen misfortune forced him to plan his funeral and secure his salvation far away from home. Since transporting his body back to his distant hometown in Germany was impossible, he decided to organize his funeral at Krakow's most important church. He made bequests to the long-standing

\footnotetext{
258 Hanna Zaremska, Żywi wobec zmartych, 748.

259 LT, fol. $135^{-136 .}$

260 "Item X reynische gulden hat her bescheiden zu der brudirschaft alhir zu sinte Barbare und dy sal alle gerete $\mathrm{z}$ udem begrebnisse dar zu geben als leychtuch und sust noch gewonheit der brudirschaft"; LT, fol. 135 .

261 "Item was of das begrebnisse wirt gehen sal man och awsrichten zu guttir rechenunge"; LT, fol. 136 .
} 
Franciscan order and to the Carmelites, whose convent was being built at the time, because they 'specialized' in praying for the souls of the dead. In turn, he chose the Brotherhood of St. Barbara, which was affiliated with the cemetery chapel of St. Mary's Church, because he wanted to have an adequate funeral ceremony. While we cannot determine why the foreigner chose this specific brotherhood, it seems probable that his business partners in Krakow offered their advice in this matter. However, Megirszheimer undoubtedly made such a generous bequest to this brotherhood not as a member, but as a 'client' who wished to pay for the funeral services it provided.262

The bequest made by cloth maker Wincenty Czanser in 1457 was similar in nature. ${ }^{263}$ Czanser left his entire estate to his wife, Dorota, provided that she pay for a psalter to be said for the sake of his soul at St. Stephen's Church, which was probably his parish church. He also stated that a Gregorian Mass should be sung at his grave by the Brotherhood of St. Francis. ${ }^{264}$ In this case, the brotherhood at the so-called Hungarian chapel provided not only for burial in the church, but also for prayers during a Mass celebrated by the brotherhood's priest. ${ }^{265}$ The fact that fraternities offered funeral services and were tasked with commemorating their dead is also evidenced by the so-called Book of the Dead maintained by the Brotherhood of the Blessed Virgin Mary. ${ }^{266}$ Hanna Zaremska, who has analysed the names listed in the register, points out that the Book of the Dead only lists people whose mourning relatives (widows, widowers, children, etc.) paid for a Mass for their soul. The register includes

262 "From the very beginning, or at least since the fifteenth century, religious confraternities considered funeral services a form of communal activity outside the corporation. This is probably why they were called funeral fraternities in literature"; Hanna Zaremska, Bractwa, 141.

263 LT, fol. 47.

264 "Item Dorothea uxor iam dicti Vincencii debet et promisit de bonis ipsius mariti disponendo unum psalterium ad legendum pro anima sua apus sanctum Steffanum. Item unum Tricesimam decantare mittere debet apud sanctum Franciscum in fraternitate et sepulturam ibidem faciendo"; ibidem.

265 "It seems that burying bodies in parish churches was not a result of agreements between corporations or their initiative, and the decision depended instead on the position and financial standing of the family of the deceased. Sometimes burial in a church was provided for in the will. The matter of burying the dead in monasteries was completely different. In Poland, from the early Middle Ages, monasteries enjoyed liberam sepulchram - the right to accommodate the corpses of those who had chosen them as their final resting place. This legal custom was reinforced in the struggle between parish clergy and mendicant congregations. Therefore, there is no reason to believe that the burials of members of corporations associated with monasteries did not take place on their grounds."; Hanna Zaremska, Bractwa, 142-143.

266 Józef Mitkowski, Księga zmartych, 76. 
not only members of the brotherhood, but also their relatives ${ }^{267}$ For example, the patrician Jacob Borneysen increased his wife's dower in his very short will, 268 which he drafted on his deathbed, but he did not instruct the members of the municipal council who came to visit him during his illness to make any other pious bequests. Nevertheless, his name (Vor Jacob Bornayzen) is included in the Book of the Dead of the Brotherhood of the Blessed Virgin Mary. ${ }^{269}$ Perhaps Borneysen was a member of this brotherhood or perhaps he had made some sort of donation to it during his life. ${ }^{270}$ It seems more probable, however, that it was his wife and children, to whom he left his entire estate, who paid the Brotherhood to organize a proper funeral for him. Such a wish was expressed directly by another member of the patriciate, councillor Peter Lang, in 1479. Lang left his entire estate to his wife and children, but he ordered them to make pious bequests on his behalf after his death (werg der barmherczikeit). One donation was to be made to St. Mary's Church and the other to pay for the altarpiece (on which Veit Stoss was working at the time) "in accordance with [Lang's] wish."271 It is not known whether Lang's family followed his instructions. Peter Lang's name is not listed in the Book of the Dead, unlike his wife, Agnes's. ${ }^{272}$

By the end of the fifteenth century, nearly 700 people were listed in the Book of the Dead kept by the Brotherhood of the Blessed Virgin Mary. This demonstrates the popularity of the brotherhood and the funeral services it provided, especially in the late fifteenth century. No less important were the special indulgences that all of these brotherhoods received. ${ }^{273}$ The sheer number

267 Hanna Zaremska, Bractwa, 71.

268 CONs. 428 , fol. 437 (1441).

269 Józef Mitkowski, Ksiega zmartych, 85.

270 This may be evidenced by a record in the inventory of the St. Mary's Church vault.: "Item eyne kamchen kasel von slechten blumen, gemeyne, Borneisyn dedit”; Najdawniejsze inwentarze, 76 .

271 "Ouch was her yn bevolen hat awsczurichten in werg der barmherczikeit alhir zurr Unsir lieben frawen zu der kirchen und ouch zu der toffil, das sullen sy mit fleysse awsrichten alse her yn hat bevolen und wol vortrawet"; LT, fol. 125 .

272 Józef Mitkowski, Ksiega zmartych, 87.

273 "Indulgences were an opportunity offered by the church to believers. Fraternities helped to seize this opportunity. They also ensured the memory of their members would be honoured after they passed away. The chapels of the corporations served as places of mourning and supplication for souls in purgatory. There, pro defunctis Masses were celebrated every quarter, during which the custom was to read out long lists of those who had died in recent years; this was an expression of the care taken to ensure that prayers 'sent' to heaven were 'addressed' accurately, thanks to listing the names of those with whom the earthly communitas was united in their efforts to gain eternal peace"; Hanna Zaremska, Bractwa, 140. 
of religious and professional fraternities affiliated with parish and monastic churches (including such popular organizations as the Brotherhood of St. Barbara) demonstrates just how popular and influential such confraternities were in the religious and social life of Krakovian burghers.

\section{Parish Identity and Ties to Other Religious Institutions in the Medieval City}

The observation that a person in the Middle Ages was, first of all, a member of their parish community, while true of those living in the countryside, is less applicable to parish life in a large medieval city: "Unlike the rural parish, large parishes like those in the city no longer functioned as a homogeneous social community. The urban parish offered fewer opportunities for interaction and collective participation, elements necessary for the creation of a true community in the psychological and social sense."274 Nevertheless, despite both the wide-ranging religious 'offering' in Krakow, manifested in the activities of mendicant orders and various fraternities, as well as the growing popularity of private and family-oriented means of worship, the parish church remained the primary reference point in the city's social and religious life. It was where burghers married, baptized their children, and often sought to be buried. As mentioned earlier, the wealthiest families had strong ties to their parish church and often acted as patrons of the church, both because the pious bequests of their predecessors required them to do so, and because the church was the site where the mortal remains of their kin lay. These strong ties are particularly visible in the case of testators who had moved to Krakow from other towns, because their bequests tended to reflect their beliefs and emotions rather than local customs. As noted above, Wilhelm Megirszheimer allocated 400 florins to found a perpetual Mass for his soul in his hometown Thunkilspul. ${ }^{275}$ The will of another foreigner, John Raisser from the Bavarian town of Memmingen (Mammyngen), is also interesting in this context: "For the love of God and his most excellent mother Mary and for the salvation of his soul and the consolation of his relatives," ${ }^{276}$ he donated 500 Rhenish florins to found a perpetual altarage in the parish church of St. Gallen (about $100 \mathrm{~km}$ from Memmingen). Like Wilhelm Megirszheimer, John Raisser made bequests to Krakow's churches to pay

\footnotetext{
274 Ibidem, 155.

275 LT, fol. 135-136 (1482).

276 "Czum irsten hot her czum lobe gotis und seynir hochwirdigen mutter Marie czu seynir zelen zelickeit und seynir frunden czu troste”; sCAB. 8, fol. 598 (1476).
} 
for his funeral ceremony. Raisser bequeathed five grivna to St. Mary's Church (for his funeral), another five grivna for a monstrance at the Church of the Holy Cross, ${ }^{277}$ and three grivna "to St. Hedwig," probably in the hope that the poor at this hospital would attend the funeral and pray for his soul. For this same reason he donated 24 grivna "for his funeral and for the poor." This money was most likely to be given to the poor as alms during the funeral. ${ }^{278}$

The 1443 will of the wealthy Krakovian merchant Thob Johan is also notable. In addition to generous bequests to St. Mary's Church and to fund various "works of charity," Johan also instructed that the money from the sale of his house be used to fund an altarage in his private chapel at St. Mary's Church. ${ }^{279}$ In addition, he made several smaller bequests to Krakow's hospitals. Moreover, his donations were not limited to religious institutions in Krakow, and included leaving a considerable sum of money to various churches in his home town of Brzeg. Among these were an annuity of the amount of ten grivna each for the suburban church of St. Anthony in Strzelniki, the parish church in Brzeg, and the Order of Saint John, located in the parish courtyard (Pharhoff den Creuczigern). Johan also allocated 36 grivna in annual rent for a perpetual Mass at the parish church in the city. ${ }^{280}$

277 He followed the same procedure as many of Krakow patricians, who, before their death, donated liturgical objects to clergymen, fraternities or churches in Krakow. These objects were simultaneously a kind of votive offering and obliged, in this case, a convent of clergy responsible for the largest hospital in Krakow, to participate in the funeral ceremony.

278 "Item alhy czu Crakow czu unsir liben frawen kirchen funf margk czu seynen begrebnisse, Item do selbist czu dem heiligen crewcze czu der monstrancia funf marg. Item czu sinte Hedwig den armen sichen drey margk. Item sust czu seynir beygraft und armen lewten fier und czwenczig margk"; sCAB. 8, fol. 599 .

279 "Ite, czu seyner Capellen und Elter czu unser frawen beschit her dy helfte und eyn achteteyl sejnes hausis of der brudergassen das man das vorkeuffen sal und czinse dor von keuffen und gibt das selbe altare Nicolao Asschirhaus seyner diner und noch des tode sal das leen an Hannus seynen stifson und Henseln seynen son sterben und noch der tot ap si ane erbe storben sal das salbe leen sterben an dy hern Ratman und noch Asschirhaus tode sullen di abgenanten sone ader di hern Ratman ap is an si storbe das leen geben deme wachern der of dy selbe czeit wirt seyn in der pfarkirchen"; LT, fol. 7 .

280 "Item von den LXVI marg czinse dy her czu Breslaw hot gebt her X mrc czinse ken Brige czu seinte Antonien kirche. Item czr pfarkirchen ouch czum Brige in der stat gibt her ouch X marg von dem obgenante czinse czu Bresla. Item X marg doselbist czum Brige of den pfarhoff den Creuczigern ouch dem czinse czu Bresla. Item czu Bresla czu dem heiligen Leichnom dy oberige XXXVI marg und XXXII bemesche groschen czu eyner stiftunge eyner ewigen messen do selbist czu seyner selen selikeit czu singen czu wilchen messe sy eyner sunderlichen eltir benumen sullen of deme si gesungen sal werden"; LT, fol. $7-8$. 
Other Krakovian burghers also felt a strong connection to their former parishes, and made testamentary bequests to them. The Krakow alderman and councillor Serwatius not only donated 30 grivna to St. Mary's Church, but also made bequests of 100 grivna to the parish church in Nowy Sącz. He also donated 30 grivna each to the hospital of the Holy Spirit and the Franciscan church in Nowy Sącz. ${ }^{281}$ The councillor Paul Ber donated, among other things, a chasuble and a missal to the parish church of St. Nicholas in Głogów, in which, as he stated, his parents and other family members were buried. ${ }^{282}$ Krakovian burghers who were not counted among the city's patrician elite and whose ancestors were probably not buried in their former or present parish churches, still made generous donations to them. The maltster Nicholas Kmitta left four grivna each to the Corpus Christi parish church in Kazimierz and to the parish church of St. Stephen in Krakow, which might indicate that he had moved from Kazimierz to Krakow. ${ }^{283}$ Bernard Philippi de Luboyna left his fish farm to the parish church in Mikanów in order to fund a weekly Mass for the dead.284 The tailor Jarosz not only made generous bequests to St. Mary's Church, the Brotherhood of the Blessed Virgin Mary, and four Krakow monasteries (those of the Bernardines, the Dominicans, the Carmelites and the Franciscans), but also donated his expensive damask bedspread (to be turned into a chasuble) and some silverware to the parish church in Zator, which was most likely his former parish church. ${ }^{285}$

Although parish churches in Krakow had to 'compete' with many other religious institutions, and thus did not have a monopoly on the teaching of Christian doctrine to the faithful, they remained the most important places of worship for the majority of medieval burghers. Most burghers had wellestablished personal and family ties with their parish churches and regularly attended Sunday Mass there. In spite of a lack of evidence in the analysed wills, we can assume that shared participation in religious services and the social bonds formed by this common experience must have been an important factor integrating the medieval burgher community. While in the fourteenth and

\footnotetext{
281 SCAB. 6, fol. 139 (1437).

282 SCAB. 8, s 270-271 (1467).

283 CONs. 428 , fol. 21 (1412).

284 "Primo piscinam meam ante villam Luboyna do et assigno plebano Ecclesie parochiali in Mikanow et omnibus aliis ipsius Ecclesie sequencibus id est rectoribus dicte Ecclesie dictam piscinam pro se habendam utifruendam temporibus perpetuis ita tamen quod dicti Rectores Eclesie presentes et futuri omnia septimana unam missam pro defunctis legendam"; LT, fol. 71 (1461).

285 LT, fol. 151-152 (1492).
} 
fifteenth centuries religious confraternities provided an attractive option for a small group of pious burghers, most city residents preferred the social and religious community formed by their parish church. Indeed, most pious bequests in that period were made to five parish churches in Krakow (St. Mary's Church, the church of the Holy Cross, St. Stephen's Church, All Saints Church, St. Anne's Church) and a number of parish churches in Kazimierz (the Church of Corpus Christi, St. James's Church, St. Michael's Church and St. Stanislaus's Church), Kleparz (St. Florian's Church) and Wesoła (St. Nicholas's Church). ${ }^{286}$ In the fifteenth century, nearly $6 \circ \%$ of all testamentary bequests were made to parish churches and over $75 \%$ of such bequests were made to St. Mary's Church - Krakow's most important religious building. ${ }^{287}$ These numbers not only show that people wished to ensure their salvation, but also demonstrate the high social status of most testators, who were parishioners of St. Mary's Church. While wills in which no pious bequests were made were not taken into account in this study, we can still observe a clear convergence between the number of bequests made to St. Mary's Church and the number of wealthy and very wealthy testators in Krakow. ${ }^{288}$

In terms of form and structure, bequests made to other parish churches in Krakow were similar to those made to St. Mary's Church. However, such donations were clearly secondary to other dispositions and usually a matter of convention, as the practice of donating small amounts to as many religious institutions as possible was common in the Middle Ages. Testators wanted to ensure that as many lay people and clergymen as possible would pray for their soul, delivering them from Purgatory or shortening the time spent there through "the power of mass prayer." For example, the purse maker (beuteler) Stephen donated one grivna each to three parish churches in Kazimierz (the Church of Corpus Christi, St. James's Church and St. Catherine's Church), three parish churches in Krakow (All Saints Church, St. Mary's Church, St. Anne's Church), four orders (the Franciscans, the Dominicans, the Carmelites, and the order of St. Mark), and two hospitals (the hospital of the Holy Spirit and St. Hedwig's Hospital). Thus, this moderately rich Krakow burgher spent only

\footnotetext{
286 Elżbieta Piwowarczyk, Legaty testamentowe ad pias causas, 101-136; Aleksandra Witkowska, Przestrzeń sakralna późnośredniowiecznego Krakowa, in Ecclesia et civitas, 39-41; Jakub Wysmułek, "Przejawy religijności mieszczan krakowskich na podstawie XIV-wiecznych testamentów i zapisów pobożnych," Odrodzenie i Reformacja w Polsce 54 (2010), 9o-94.

287 Elżbieta Piwowarczyk, Legaty testamentowe, 103, 114-115.

288 See chapter 2, section 5, p. 152.
} 
twelve grivna in ensuring that as many as twelve different religious institutions in the Krakow agglomeration would pray for his soul. ${ }^{289}$

The wealthy widow Anna Florianinne left similar instructions in her 1459 will. Although it contains elements that can be found in many other bequests of last will, it stands out in terms of the religious commitment of the testator and the degree of thought she put into the dispositions she made. For these reasons, it is reproduced here in its entirety:

I, Anna Florianinne, a burgher woman of Kraków, declare this to be my last will and testament. First of all, I ask the executors of my will [vormunde] to prepare my funeral in such a way as to ensure the salvation of my soul, to which end I leave 10 florins. Thirty Masses for my soul should be said in each of the following churches in Kraków: St. Mary's Church, at the hospital, St. Barbara's Church, the Dominican Church, All Saints Church, St. Francis's Church, St. Anna's Church, St. Stephen's Church, St. Bernardine's Church, the Church of Corpus Christi and St. Catherine's Church. The priests who will celebrate the Masses should be given 30 groszy. In addition, I leave 10 florins for the fabrica of St. Mary's Church in Kraków. I likewise donate 10 florins for the fabrica of St. Bernardine's Church in Stradom. To St. Catherine's I bequeath 10 florins for the brotherhood. For the Brotherhood of St Bernardine I order the purchase of two warps of fabric for clothing. To the poor in three hospitals, St. Hedwig's, St. Valentine's, and St. Leonard's beyond Kazimierz, I leave five florins for clothing and shoes. The executors of my will should carry out [these dispositions] in accordance with current needs, acting on their own judgment. In addition, I bequeath 20 florins to the poor at the hospital in Kraków, for the executors of my will to buy meat, fish and beer each week until all the money is spent. I bequeath 10 florins to the brotherhood at the parish church in Krosno. I leave five florins to the Franciscans in Krosno so they can renovate their monastery. I give five florins to the poor at Krosno's hospital. I give five florins for the building of a hospital for poor students at Hospital Street in Kraków. To the poor brothers [the Carmelites] from the New Monastery I bequeath 30 groszy to say 30 Gregorian Masses for

289 “[...] czu desen nochgeschrebenen kirchen, alse czum Heiligen Leichnam, czu sinte Jocob und czu sinte Katherin czu Kazmer, Czu der Barfussen, czu der Allen Heiligen, Czu der Pawlern, Czu unser liben frawen hy in der Stat, Czu der Hornechten, czu sinte Annen, und czum Newencloster czu iczlicher kirchen besundir eyne marg czu dem gebewde, und das geld sal man geben den kirchenbitern und nicht den pristern. Item den sichen Im Spital hy czu Cracow eyne marg und czu sinte Hedwig ouch eyne marg”; cons. 428, fol. 379 (1437). 
the release of my soul. I give same to St. Stanislas's Church and St. Florian's Church to pay for 30 Gregorian Masses for the release of my soul. I bequeath three florins, a down quilt and one set of bed linen to John, a mansionary at St. Barbara's Church, who replaced Stanisław Geweitfewer. To Jaczke and Jacob, two priests at the castle, I give three florins each. I give five florins to the Franciscan Observants [the Bernardines] from Stradom to purchase clothing. I leave two quilts, eyn pfel, four bed sheets and one chest to my servant Dorota. I donate small pieces of linen that are to be found around the house to Magdalene at St. Bernardine's so that she can make a corporal and give it to the priest, as I have instructed. All my fabrics (fechil, dromleyn etc.) should be given to the Bernardine sisters. I leave 50 elbows of linen for making albs to be given to churches in need of them. To the shoemaker Lawrence, who has a blessed daughter [seligen tochter], I leave three florins to use for whatever he needs. I leave my royal dress [koniglyn korssche] and my tablecloth [decke] to Benigna, wife of John Meisner. I give my old dress and the coat I wear every day to my servant Dorothy. The yarn that will be found around the house, both small and large, should be given to Benigna, wife of John Meisner. The linen canvas made by her should be used to make shirts for the poor who need them. I also give two florins to John and Lucas. Moreover, so that this will is executed properly, I ask the executors of my will to sell all my household items and all other remaining goods and donate the money for works of charity. I also disinherit all my family members and relatives whom I do not know and do not. I name John Meisner, a butcher, and Stanisław Czipser, a furrier, as the executors of this will. They have the right to execute this will and perform works of charity, as stated in the will. This notwithstanding, I have the right to dispose of my estate as long as I live. ${ }^{290}$

In this will, Anna Florianinne demonstrates her religious commitment and her understanding of how to effectively perform 'works of charity.' This will distinguishes her from many other testators, who generally made less thoughtful and more schematic bequests. However, like Stephen, a purse maker, ${ }^{291}$ Anna Florianinne wished to ensure that as many people as possible would pray for her soul. She assumed that a Gregorian Mass was worth 30 groszy each, but she ordered them in as many as fourteen houses of worship, including parish

29 LT, fol. 64-65.

291 CONS. 428 , fol. 379 (1437). 
churches, monasteries and hospitals in Krakow, Kazimierz, Kleparz, Skałka and Piasek. The testatrix also planned her funeral ceremony (Krakow's testators rarely included such instructions in their wills) and left specific instructions as to how her money should be distributed among the poor. She did not forget about her parish church, the hospital in the city or the Franciscan monastery in her hometown Krosno. Last but not least, she also made bequests to her female servant and close friends, including a very interesting bequest to a certain Krakow shoemaker who had a "blessed daughter" (die selige tochter). Anna Florianinne also demonstrated that she had ties to her parish church - she donated 10 florins for the construction of St. Mary's Church. However, she donated the same amounts to St. Bernardine's Church, which was still under construction in 1459, and to the religious brotherhood at St. Catherine's Church in Kazimierz. ${ }^{292}$ Anna's husband, the merchant Florian, who became a Krakow burgher in 1432, also left a will, ${ }^{293}$ but he did not make bequests to religious institutions, and probably delegated this task to his wife.

In terms of piety, Anna Florianinne's will also demonstrates that Krakovian burghers differed in regards to their level of religious commitment. The form of the bequest itself reflects the material situation and social position of a widow of a wealthy merchant, ${ }^{294}$ though it is notable that the will does not particularly privilege her parish church, and instead includes numerous bequests to various religious institutions and clerics with whom the testatrix was acquainted. This is probably tied to the fact that she had arrived in Krakow relatively recently and actively participated in the spiritual life of various religious communities, both in the Krakow agglomeration and in her home town of Krosno.

A survey of these wills gives one the impression that donations for the building of new churches was the preferred form of bequest for most burghers. Perhaps by donating money for the construction of a symbolic, but also very real, 'house of God' they wished to personally participate in the sacred. ${ }^{295}$ Con-

292 An interesting aspect of this bequest was the fact that the brotherhood at St. Catherine's Church had been identified as a Polish brotherhood from its very beginning: 'Fraternitas Polonorum.' Anna's Polish identity may also be indicated by the fact that she came from Krosno. Therefore, it seems characteristic that there was no bequest for other Krakow religious fraternities, including the most important 'German' brotherhood - NMP; cf. Hanna Zaremska, Bractwa, 88-92.

293 SCAB. 6, fol. 172 (1439).

294 She received from her husband a significant sum of 300 grivna as her dowry; ibidem.

295 This phenomenon was first observed by Kateřina Jišová. She quoted a vivid opinion from the period, according to which "stone will eventually win as a more durable and tangible witness of time, which cannot be easily destroyed"; cf. eadem, "Testamenty pražských 
sidering that fourteenth-century Krakow was a vast building site with many churches under construction, its citizens had a wide array of choices. This is evidenced by the pro fabrica ecclesiae bequests appearing in many wills. For example, Margaret, wife of Peter Wilrich, asked that her estate and movables be donated either "to the poor" or "for construction [of a church]."296 A similar bequest was made by Martin Jung, in which he left sixteen grivna to be given either to St. Stephen's Church or a different church "under construction outside the city" 297

A characteristic feature of some donations made by Krakovian burghers were bequests to pay for the construction of specific parts of a church or elements of its furnishings. This shows that burghers felt responsible for taking care of, decorating, and furnishing their local churches and wished to personally participate in the construction of a new church, or at least some part of it. For example, burghers made donations pro fabrica ecclesiae ${ }^{298}$ or specific bequests to pay for a new roof, ${ }^{299}$ windows, ${ }^{300}$ tower roof, ${ }^{301}$ pipe organ, ${ }^{302}$ church bell ${ }^{303}$ or main altarpiece. ${ }^{304}$ It is also possible that priests or preachers instructed the faithful as to what they should buy or finance for a specific church.

\section{$5 \quad$ Religion Civique - Communal Religiosity}

The relative weakness of parish communities (due to the large number of religious institutions active in the city) and the ongoing formation of a civic

měštanů v pozdním středověku. Religiozita, sociální rozvrstvení, majetkové a rodinné poměry novoměstských měštanů (1421-1533)," in Pierwsze polsko-czeskie forum młodych mediewistów. Materiaty z konferencji naukowej, Gniezno 27-29 września 2005 r., ed. Józef Dobosz (Poznan: Instytut Historii UAM, 2007), 299.

296 "[...] das se erbe vnd beweglich gut, was se noch ir lossen wirt, sullin in dy werk der barmherczikeit wenden armen leuthen, adir, wy se en her noch wurde beuelen"; sCAB., no. 1773-1774 (1393).

297 "[...] beuele ich XVI marg czu sente Stephan czu der kirchen, adir, wirt man bawen eine kirche hy vor der stat, so sal man dy XVI marg dorczu gehen"; sCAB., no. 1816 (1393).

298 For example, in the note on the will of Gertrude, widow of Nicholas of Kluczbork: "Henricus Schere petitor ecclesie sancte Marie Resignauit vnum Bancum panis, qui pro parte dimidia ad fabricam ecclesie sancte Marie per Dominam Gerdrudim quondam Relictam Nicolai de Cruceburc erat legatus"; NKiRMK, no. 1548 (1345). LT, fol. 31 (1451); SCAB. 8, fol. 27O-271 (1467); LT, fol. 154 (1494).

300 SCAB., no. 2092 (1395); SCAB. 6, fol. 338 (1445); LT, fol. 68 (1460).

301 LT, fol. 27 (1452).

3 O2 CONS. 428, fol. 243(1428); LT, fol. 154 (1494), 165-166 (1501).

303 SCAB. 6, fol. 184 (1439), 188 (1439).

304 LT, fol. 92-93 (1467), 108-109 (1473), 120-121 (1476), 119-120 (1477). 
identity - conceived of as a local patriotism and sense of community delimited by the boundaries of Krakow's sphere of influence as an urban centre ${ }^{305}$ were important causal factors in shaping the nature of burgher religiosity. This included not only the phenomena discussed above, related to religion in its private, familial, corporate and parish dimensions, but also by the urban milieu and factors outside of parish life. This can be seen in the tendency described earlier for testators to make pious bequests to churches located throughout the Krakow agglomeration. This indicates that they must have identified with a wider community, i.e. the city organism as a whole. The pious bequests they made (whether to the Church or to the 'poor') were in the interest of this wider community, and in return they expected this community to respond to their needs, remember them and pray for their souls.

To understand this urban model of religiosity we have to consider two interrelated phenomena. The first is the burghers' function within the wider urban community, including religious life (manifested most clearly during annual Corpus Christi processions); 306 the other is the way in which the municipal authorities shaped these relations from above. It is worth examining the latter phenomenon here, as it also influenced the institution of the will.

Western historiography has long been aware of the phenomenon of municipal authorities assuming 'patronage' over religious life in the community, coining the terms religion civique in French, bürgerliche Religiosität in German and civic religion in English to refer to it. ${ }^{307}$ André Vauchez defines it as essentially being "the appropriation of values of the religious life by urban powers

305 Halina Manikowska, Religijność miejska, 19-24; Roman Czaja, “Tożsamość mieszczaństwa hanzeatyckiego w średniowieczu," in Aetas media, aetas moderna. Studia ofiarowane profesorowi Henrykowi Samsonowiczowi w siedemdziesiąta rocznicę urodzin, ed. Agnieszka Bartoszewicz, Wojciech Fałkowski, Halina Manikowska, Antoni Mączak, Karol Modzelewski (Warszawa: Instytut Historyczny Uniwersytetu Warszawskiego, 200o), 182-191.

306 An important testimony to the importance of the Corpus Christi procession is the bequest from Paul Gortler's testament of 1474, in which he donated, according to the will of his father, half of the stall towards the organization of this procession "with flags and candles as before and forever and ever," "Czum irsten zo hat her bescheiden seinen halben krom als oben des vor dy ander helffte her Marcus ist zu dem testament das seyn vatir gemacht hat zu ere des heiligen leichnams ouff seyn teyl, das sulche processio vor dem Heiligen Leichnam mit fanen mit lichten alsus denum bis do her gehalden isteynen ewigen vorgang, und bestehn habe"; LT, fol. 106 (1474); cf. Hanna Zaremska, "Procesje Bożego Ciała w Krakowie w XIV-XVI wieku," in Kultura elitarna a kultura masowa w Polsce późnego średniowiecza, ed. Bronisław Geremek (Wrocław: Zakład Narodowy im. Ossolińskich, 1978), 25-40.

307 Marek Słoń, Religijność komunalna, 9-10; Andrew Brown, Civic Ceremony and Religion in Medieval Bruges c. 1300-1520 (Cambridge: Cambridge University press, 2011); Trevor Dean, The Towns of Italy, 63-71. 
for the purposes of legitimation, celebration and public well-being." ${ }^{308}$ Polish historians have coined their own terms and definitions in recent years. For example, Halina Manikowska has translated the French term into Polish. She writes about 'urban religiosity', emphasizing the role played by the municipal authorities in shaping this phenomenon. ${ }^{309}$ Marek Słoń, in turn, suggests that the term 'communal religiosity' describes "the semantic field in question" more accurately. ${ }^{310}$ Previous studies have identified several major areas of urban religiosity. These included the cult of the patron saint of the city, support from the municipal council in the creation and functioning of religious fraternities, funding provided by the municipal council for various religious institutions in the city, governance over hospitals and schools, the participation of councillors in processions and other forms of public worship, the patronage of municipal authorities over churches, chapels, altars and prebends financed by burghers, and commemorating deceased members of the urban community. ${ }^{311}$ When seen in such terms, the municipal authorities' participation in the sphere of the sacred can be considered an additional dimension of urban religiosity.

The analysed wills illustrate the links between power and religion in the medieval city and how the institution of the will comprised an element of religion civique. We first see signs of the municipal authorities' involvement in the authentication and execution of pious bequests in the early fourteenth century. This tendency is evident in Sulisława's will from 1303: pious bequests of a butcher stall, market stall and bread stall (Brotbank) were to be made by Albert, the vogt of Krakow, as the executor of her will. The butcher stall was to be sold for 24 grivna and the money given to the Franciscans. Albert was also

308 André Vauchez, La religion civique à l'époque médiévale et moderne. Chrétienté et islam: actes du colloque, Rome 1995, 1, cited in Trevor Dean, The Towns of Italy, 63.

309 "Religion civique means more than just burghers' religiosity, and is distinct especially in its forms of worship and devotional practices from rural religiousness. It is defined as a set of religious phenomena - connected with worship, piety and urban institutions - in which secular governance and local authorities subjugated to it to various degrees (city master, city council, guild authorities) played an essential role. Through organising municipal festivities and manifestations of public order, these authorities appropriated the values associated with religious life (e.g. for purposes of legitimacy)."; Halina Manikowska, Religijność miejska, 15 .

310 Marek Słoń, Religijność komunalna, 9-21.

311 Jörg Oberste, "Macht und Memoria. Religiöses Leben und soziale Netzwerke des Regensburger Patriziates im später Mittelalter," in Regensburg im Spättmittelalter. Bestandsaufnahme und Impulse, ed. Schmid (Regensburg: Schnell \& Steiner, cop., 2007), 25-48; Trevor Dean, The Towns of Italy, 63-71; Halina Manikowska, Religijność miejska, 11-34. 
to buy half of the market stall on similar terms for a fair market price. ${ }^{312}$ The vogt was also tasked with donating the income from the bread stall for the fabrica of St. Mary's Church. He was also given the option to purchase this stall for himself and his heirs (with the consent of the municipal council). ${ }^{313}$ Albert was thus the executor of the will, and at the same time, one of its beneficiaries. The municipal council, whose official written consent he needed to purchase the stall and whose seal was affixed to the will, ${ }^{314}$ played a secondary role.

The role of the municipal council in the execution of wills grew in importance after a rebellion led by the vogt Albert in $1311-1312 .{ }^{315}$ For example, we learn from a 1317 entry pertaining to the will of the first wife of the alderman Henry Srolle that the provincial vogt Wilhelm, acting on behalf of a Dominican friar named John, passed on the donation in question to the municipal council and the city. ${ }^{316}$ In 1318, Marusza, widow of Wilhelm of the Orient, ${ }^{317}$

312 The other half was supposedly given to a man named Minardus, a Franciscan.: "Item de instita sic dispono, quod mediam confero fratribus predicatoribus, in qua Michachel filius simniconis residet, tali interposita condicione, quod prefatus dominus albertus eandem medietatem instite aput prescriptos fratres pro se et ipsius posteris redimat, sicut tunc taxata fuerit, iure hereditario conseruando. Insuper mediam institam do fratribus minoribus, in qua minardus inhabitat, tali caucione intermedia, quod ipse minardus aput ipsos fratres eandem medietatem (s) instite emat pro se et suis successoribus, prout tunc estimata fuerit, ipsam inperpetuum possidendo"; KDM K, vol. 3, no. 368.

313 "Item vsum vnius banci panis concedo ad opus beate virginis marie, cousque antedictum opus consumatum fuerit ex integro, constituens sepedictum dominum albertum procuratorem et exsecutorem eiusdem banci; consumato opere eiusdem ecclesie ipse dominus albertus pro se et suis successoribus cum consensu consulum exsoluat, si sibi visum fuerit et consultum, pecuniam vero, quam pro ipso banco dederit, ponet ad vsum eiusdem ecclesie et conuertat"; ibidem.

314 Most likely, it was councilors who were being ambiguously referred to as "honorabilium virorum civium cracoviensium"; ibidem.

315 "Just as the location privilege of Krakow opened the way to the creation of the institution of the council, the fall of Albert made it possible for the Krakow patricians who formed this council to assume real power over the city. In the first forty years of its existence, the Council of Krakow evolved from a body that originally supervised trade in the city to a body that determined the shape of the city's politics."; Marcin Starzyński, Krakowska rada, $57-58$.

316 Two or three words were scratched out, so it is not possible to determine what the donation concerned, but due to the similarity to other provisions from that time it was probably a stall, a bench or a slaughterhouse: "Item in eodem Iudicio Vilhelmus aduocatus prouincialis sub nomine fratris Iohannis predicatoris de ordine predicatorum vnum quod Henricus Srolle legauerat fratribus predicatoribus pro testamento prime uxoris sue, Consulibus et Ciuitati Crachouie resignauit"; NKiRMK, no. 411 (1317).

317 Jerzy Rajman distinguishes between Wilhelm, the councilor and provincial mayor, and Wilhelm of Orient, who lived at the same time, "'Unsere libe Fraue.' Wspólnota miasta i kościoła w Krakowie w XIV wieku," Średniowiecze Polskie i Powszechne 4 (8), 155-156. 
stated that her husband had made a will when he was still alive, donating one grivna in annual rent to St. Mary's Church (specifically to buy candles). ${ }^{318}$ The municipal council then advised Marusza to sell the rent of eight grivna and donate the money to St. Mary's Church. ${ }^{319}$ The growing role of the municipal council is also evidenced by other wills. In the 1325 will of Konrad the maltster, councillors acted as executors of his will, donating Konrad's house to St. Mary's Church. ${ }^{320}$ In turn, the burgher widow of Otton, in her 1340 will, ${ }^{321}$ chose councillors as the 'patrons' of one of her testamentary dispositions. The widow donated to the city half of a stall, with the condition that she could continue using it as long as she lived; after her death, however, the councillors would run her stall and use the profits to benefit the poor and for the salvation of her and her husband's souls. The widow emphasised in the bequest that "all this should be done with the advice of the councilors." 322 The municipal council thus not only guaranteed the execution of the will's dispositions, but because the body was permanent and collegial in nature, it also ensured something highly sought after by pious burghers - that their legacy funding would continue for many years (and, according to the testators' intentions, indefinitely).

Such a guarantee of permanence was indeed important, especially in the case of generous pious foundation, which were meant to continue 'working'

318 "Item in eodem iudicio bannito domina Marussa relicta Wilhelmi protestata fuit et publicavit coram predictis advocatis et scabinis, quod ipse Vilhelmus maritus eius faciens testamentum, unam marcam grossorum censualem super fundum et mediam curiam Lexandri in platea sutorum annis singulis ecclesie sancte Marie Virginis dedit et legavit pro luminibus in eadem ecclesia conparandis et pro salute anime sue ordinandis"; NKiRMK, no. 477 (1318).

319 "Item in eodem Iudicio domina Marussa relicta Vilhelmi de Consilio dominorum Consulum vendidit vnam marcam Censualem que iacuit super Curiam Lexandri in platea sutorum pro octo marcis Grossorum, que pecunia data est et donata ad fabricam Ecclesie sancte Marie virginis. Et ipsa domina Marussa eandem marcam censualem dicto Lexandro resignauit"; NKiRMK, no. 478 (1318).

320 "Item predicti Consules mediam Curiam cum fundo ad opus Ecclesie sancte marie assignatam pro testamento Conrado braseatori vendiderunt et in predicto iudicio iure hereditario resignauerunt, que iacet in platea sancti ffloriani prope Curiam relicte Sere in acie"; NKiRMK, no. 75 o (1325).

321 She may have been Alusha, a testator from 1321, a widow of an alderman Otto; NKiRMK, no. 616 (1321).

322 "Eodem Anno et die resignauit Relicta Ottonis medium Cramum ciuitati, ita quod interea quando uixerit, debet in Cramo stare, et post mortem suam Consules loco ciuitatis debent se intromittere et censum dare infirmis; Si autem venderetur Cramus, pecunia non alias, quam pro infirmis et utilitate ipsorum est conuertenda pro animabus mariti eius et uxoris iamdicte, et hoc totum fieri debet cum consilio dominorum Consulum ciuitatis"; NKiRNK, no. 1407 . 
indefinitely to ensure the salvation of the testator and their family (i.e. by making sure that someone would always pray for them) and commemorate their achievements among the living. This is why burgher testators who founded chapels, altars and perpetual Masses chose councillors as patrons of these bequests. This solution seems natural because the wealthiest testators usually had strong ties to the municipal authorities, and it was only natural to entrust one's relatives or friends from the same social circles to act as the executors of one's will. For example, in his 1369 will, councillor Nicholas Edel (Edeling) donated his stall and two grivna in rent to the Dominicans, asking them in exchange to celebrate a daily Mass for the souls of all his ancestors and descendants. ${ }^{323}$ As the executors of the will, the municipal council administered the rent and ensured that the Dominicans carried out their end of the deal. The money was to be paid twice a year, but in the event that the Dominicans breached the contract, the municipal council had the right to withdraw from it and donate the money to the sick at a hospital or for other 'works of mercy.'324

In setting up a foundation for two altars - one in St. Mary's Church and one in All Saints Church (both dedicated to St. Anthony, blessed Dorothy and martyrs), the wealthy mine administrator Gotfrid Fattinante of Genoa appointed Krakow city councillors and Spytko of Melsztyn, the second voivode and starost

323 "Honorabilis vir Nicolaus Edelingi nobis conconsul, dum simul in pleno sederemus consilio, nobis Magnarum precura instancia intimitis suplicauit, ut assumpta nobis nomine Ciuitatis nostre Instita sua in acie in Medio institarum sita et Duas Marcas polonicales currentis monetę, nos aut qui pro tempore fuerint Consules Ciuitatis constituti, de pretorio singulis annis elemosine perpetue ipsis Religiosis viris fratribus predicatoribus Conuentus dicte nostre Ciuitatis daremus. Cuius elemosine virtute idem fratres predicatores ipsorum exigente devocione ad vnam missam cottidie in Capella eiusdem Nicolai Edelingi celebrandam in ipsius predecessorum omnium et posterorum suorum animarum remedium salutare salutare vitro se exhibuerunt firmiter astringendo, prout in eorum literis desuper confectis luculencius continetur"; NKiRMK, no. 1705; cf. Józef Mitkowski, « Mikołaj Edeling, » in PsB, vol. 6 (Krakow: Polska Akademia Nauk, Polska Akademia Umiejętności, 1948), 201.

324 "Nos vero Consules predicti nostro ac memorate Uniuersitatis Ciuitatis nomine antedictam nobis assumpsimus et assumimus Institam premissis ipsius Nicolai Edlingi pijs ac iustis affeccionibus amicabiliter annuentes, volumus et spondemus dictis fratribus predicatoribus eandem elemosi-nam annuam et perpetuam puta vnam marcam super Aduentum domini et aliam Marcam super Quadragesimam occasionibus omnibus atque dilacionibus propulsatis, de ipso nostro pretorio, uel qui pro tempore fuerint Consules, annis singulis elargiri. Si autem dicti fratres in dicte celebracione misse non continuarent, seu ipsam Missam, quod non credimus, quoquomodo postergarent, extunc a pretactis fratribus predicatoribus deinceps nolumus pro elemosina huiusmodi aliqualiter amoneri, Sed esse liberi ad ipsam elemosinam dandam pro refeccione langwidorum hospitalis aut in alia conuertere opera pietatis"; NKiRMK, no. 1705 . 
of Krakow, as the patrons and guardians of the two altars. ${ }^{325}$ In addition, Gotfrid Fattinante appointed the Bishop of Krakow Peter Wysz of Radolin, Spytko and members of the Krakow municipal council as the executors of his will. This demonstrates that burghers who did not have close relatives often asked the municipal authorities to serve as patrons of chapels, altars, and altarages they had founded, usually for two reasons; namely, to ensure their continuation and increase their prestige. And while for the majority of burghers, the council symbolized the primary municipal authority, in some cases, as in that of Fattinante (probably because he was a mine administrator), this function could be performed by the starost or voivode.

In 1401, councillor John Bartfal appointed members of the Krakow municipal council as patrons of his generous pious bequest, explicitly linking his choice with his desire to ensure the perpetual fulfilment of its provisions. ${ }^{326}$

325 "Primo vero in salutare anime sue remedium Cameram suam pannorum circa cameram Pauli Nutricis et sex marcas census annui et terragij, quem super fundo domus Nicolai Beidner in platea sutorum site, habere dignoscitur, pro altari in honorem sanctorum Anthonij confessoris et alme virginis Dorothee ac martyris ad taxam sedecim marcarum et valorem in ecclesia parochiali sanete Marie Virginis semper gloriose in Cracouia erecturo siue erigendo, feliciter construeturo siue construendo, cuius collacio, presentacio, prouisio seu queuis alia disposicio ad Consules Ciuitatis Cracouiensis nunc et pro tempore existentes, perpetuo pertinere debeat, de quo altari prouidit ad presens domino Petro capellano et notario suo, domum vero suam lapideam in acie circuli circa Powsuange sitam, valido viro domino Spitkoni Palatino ac Capitaneo Cracouiensi, vt per ipsum ac electos presentis testamenti executores infrascriptos alicui ciui vendi debeat, et pro huiusmodi pecunia census sedecim marcarum perpetuus comparari, et de eodem censu sedecim marcarum altare eciam sanctorum Anthonij Confessoris et beate Dorothee Virginis in ecclesia parrochiali Sanctorum Omnium in ciuitate Cracouiensi eciam de taxa sedecim marcarum erigi et construi, cuius collacio seu queuis alia disposicio ipsi domino Spitkoni ac suis posteris legitimisque successoribus perpetuis debet pertinere temporibus, dedit, contulit ac perpetuo assignauit, quod eciam altare domino lohanni presbytero domus sue et medico assignauit, superfluum vero pecunie domus predicte, si que vltra empeioriem sedeeim marcarum census annui predicti superfuerit, ipsius Spitconis consciencie recommendat. Preterea res omnes suas videlicet vestes, pelles, pellicia, togas, mensas, cistas, lectisternia ac omnia vniuersaliter et singula, quibuscumque vocitentur nominibus, nullis penitus exceptis, in predicta domo, quam inhabitat, existentes ac existencia, Nicloso cubiculario suo et familiari de presenti earundem cedens possessionem et in ipsum Niclonem transferens, cum omnimoda faciendi et dimittendi facultate legauit"; KDWac., vol. 2, no. 396, 182-183 (1393).

326 "Johannes Bartfal volbedocht als her sprach und mit gutir vornumft mit seynis selbimunt redinde, hot wedirrufin al seyn testament und lecztin willen und auch dy vormundschaft von den vormunden, das her gemacht hatte und ader dy her gekorn hatte neulich vorgehegtin dinge, wen her habe nicht vornomyn noch eren enweys wy is gemacht sey wordin, is sey seyn wort nicht sundir das ist sey seyn wille das man von alle seyme gute und gelde saleyn eltir stiften von XLII marken gemaynir muncze und nicht prag. gr., alzo mogin 
Similarly, in 1439, the municipal notary and clergyman John Stolle appointed members of the municipal council as 'patrons' of four altarages he funded in his will. ${ }^{327}$ Similar instructions were given by other wealthy burghers who made very generous perpetual foundation bequests to finance chapels, altars or prebends at an existing altar, asking the municipal council to act as patrons of these bequests. It seems that such a choice was most often made by members of the city's elite who did not have children - those who lacked heirs who could look after and continue to fund chapels, altars or prebends, and thereby commemorate the testator - and were therefore more likely to ask the municipal council for help in this matter. Gotfrid Fattinante, John Bartfal, John Stolle,

dy czinse gefolgin off den erbin dy her hot in der stat adir beusin, zo sal man sy der off gebin das leyt ander Rathmannen Wille mochte das nicht geseyn zo sulde man als obin ist geschrebin, von allern seynen gute und gelde andir czinse keufin und dorczu gebin und das lehen des eltirs sullin dy Rathmann habin und dis obingeschrebin gemechte sal czu mole ewiklich, als is gemacht ist alzo bleybin und gibt distiftunge und das lehen iczunt den Rathmannen in di hende, Sundir um alle seyn gut, das do oberig bleibit das will her beschrebin gebin adir usweysin ab man das seynen vrunden obir czu stegen und wegin gebin sal adir wy man is domite haldin sal"; cons. 427, fol. 167; cf. Krystyna Pieradzka, "Jan Bartfal," in PSB, vol. 1 (Krakow: Polska Akademia Nauk, Polska Akademia Umiejętności, 1935), 311.

327 "[...] befele ich dasselbe haws meynen hern den Ratmannen der Stat Cracow, daz sy das vorkewffen, noch seyner wirde, und unis das geld czinse kewffen czu newer belenunge, des eltirs sinte Marie Magdalene, in der kirchen unser frawen hy czu Cracow, czu newhir stiftunge pristerliches amechts steter und ewigen messe abgesundirt von allir czugehorunge der vorgen belenunge desselben eltirs und seynes vorgen eltirheren; Item das leen desselben eltirs gebe ich meynen hern den Ratmanen der Stat Cracow czu ewigen tagen, also daz sy den eltir derselben meyner newer belenunge geben sullen dem eldisten Caplan am dinste derselben kirchen unser frawen, und nimande andirs, und dorumme wenne is dorczu kompt, daz dy Ratmanne das obgenante haws vorkewffen sullen, so sal der eldiste Caplan, der of dy czeit seyn wirt am dinste der obgenanten kirchen mete wissen und raten, helffen und sorge tragen czu derselben vorkewffunge des hawsis, und czu bewarunge des geldis derselben beczalunge, und czu dem kawffe des czinses umb dasselbe geld, dorczu kyze ich in iczunt hy, wer der seyn wirt. Item dy virczig marg ierlichis czinsis dy ich hy habe of der Stat Cleynen woge und crome und brotbenke bescheide ich czu belenunge dreyen eltir in derselben pfarkirchen unser frawen hy czu Cracow, als czu des Heylgen Crewczis eltir eyn dritteyl, czu sinte Annen eltir eyn dritteyl, und czu sinte Peters und pavels elter an her Lucas Capelle steende eyn dritteyl, czu stiftunge dreyen newen pristirlichen amecht stetirund ewigir messe, dreyen newen eltirhern, abgesundirt von den czinsen und eltirhern und allir czugeherunge, dy dyselben elter vormols haben, von andirr leute belenunge und vorgar stiftunge. Item das leen derselben dreyen eltir meyner newen obgenanten belenunge und stiftunge gebe ich ouch meynen hern den Ratmanen der Stat Cracowczu ewigen tagen in sulchir weyze, als obene, daz sy dorczu iczlich mol als sich das geboren wirt entwirten sullen den eldisten Caplan am dinste der derselben kirchen am lengisten gedint hot und nymande andirs"; sCAB. 6, fol. 186. 
the village administrator Peter Filipowski, ${ }^{328}$ and Salomea, widow of Nicholas Brenner, were all childless. ${ }^{329}$ Some testators who had children, in turn, stated that in the event of the death of all their descendants the municipal council should act as the patron of the altars they had built. In her 1484 will, Catherine left her house (valued at 800 florins and located at Grodzka Street) to her grandson John. However, should John die childless, this house was to be sold and the money used to finance an altar or prebend, and the municipal council was to serve as its patron. Two Masses a week were to be celebrated at the altar. One Mass was to be dedicated to the Assumption of the Virgin Mary, and the other to Catherine's deceased relatives and all believers. ${ }^{330}$ Similar instructions were left by Thob Johan, ${ }^{331}$ Peter Schepcz ${ }^{332}$ and Michael Lang. ${ }^{333}$ They

328 In the provisions of his testaments of 1452 and 1460 , the village administrator Peter Filipowski (Philippowsky) gave his house in Shoemaker's Street to the councillors, asking them to sell the rent and use it to establish a ministry for a German preacher in St. Mary's Church.; LT, fol. 28 (1452), 66 (1460).

329 "Czum irsten kyze ich mir czu vormunde und czu vorwezer dy erben manne Johannes Syndram und Michel Goltsmed, den befele ich noch meym tode, meym haws und alle meyn gut erblich und farnde das ich iczunt habe adir hernochmols haben werde und noch meym tode lossen werde, in sulchir weyze, daz sy dasselbe haus und gut vorkewffen sullen noch seyme wirden und sullen do von czinse kewffen czu belenunge eyns Eltirs in der kirchen unsir liben frawen hy czu Cracow, czu newer stiftunge pristirlichis amechts stetir und ewigen messe und denselben Eltir, so der mit der hulffe gotis vorbrocht wirt, vorleye ich und gebe dem erben prister hern Mathis dem vicario czu unsir liben frawen hy czu Cracow, und noch Im dem Eldsten vicario und Caplan am dinste der derselben kirchen am lengisten gedint hot, und das leen desselben Eltirs gebe ich den hern Ratmanen der Stat Cracow czu ewigen tagen, alzo das sy den eltir derselben newen belenunge geben sullen dem eldisten Caplan am dinste derselben kirchen und nymande anders"; sСАв. 6, fol. 19 o.

330 "Primo lapideam suum domum eius in platea Castrensis inter Johannis Kromsch et Lazari domos iacentis quam ad octingentos florenorum existimat dedit puero Johannis filio olim Byali Jan sartoris ex filia ipsius nato tali conditione si vivet, Si autem sine prole moriretur extunc voluit et commisit ut eandemdomum executores sive tutores per eam nominandos vendant et altare in Ecclesia sancte Marie in circulo seu ministerium fundant et erigant circa quod altare volt habere unum lectorem qui leget duas missas septimanatim unam de assumpcionem sancte marie et aliam pro mortuis suum amicabus, propinquorum et consangwineorum suorum ac omnium fidelium, Cuius altaris sive ministerii dominos Consules Cracoviensis pro tempore existentes voluit esse patronos"; LT, fol. 142-143.

$331 \quad$ LT, fol. 7-8 (1443).

332 LT, fol. 137-139 (1483).

333 Councillor Michael de Czirla alias Langmichel had already obtained permission to build his own chapel in St. Mary's Church, where the founded altar was probably placed: "Primo mencionem faciens capelle, quam in cimiterio beate Marie Virginis contiguam ostio meridionali eiusdem ecclesie citerioriedificandam ipse iam antea disposuit, cuius et iam 
all established perpetual Mass funds and appointed altarists responsible for celebrating Mass, stating that the municipal council should exercise patronage over their foundations if their heirs died childless. Paul Gortler donated 300 florins to fund one perpetual altarage at St. Mary's Church (stating that two Masses a week should be celebrated at the altar). He appointed the "deputy notary John" (Johann undirstatschreiber) as the first altarist, stating that that after John's death the next altarist should be appointed by the municipal council. Later, however, that privilege was to be passed on to Gortler's distant relatives. ${ }^{334}$ In the first version of her will, Salomea Brennerinne, a childless burgher woman, asked the Krakow municipal council to act as patron for an altar she had funded. A year later, however, in a second version of her will, she granted this right to the Brotherhood of the Blessed Virgin Mary, to which she probably belonged. She seemed to have had reasons to think the brotherhood was better suited to perform this function. ${ }^{335}$

Other fourteenth-century and fifteenth-century wills also demonstrate that the municipal council exercised patronage over and supervised the performance of works of charity. For example, in 1405, Dorothy, widow of the councillor John Pauswang, gave almost her entire estate (including a generous dower, gerade, cash, and part of the inheritance she had received from her father) to the municipal council. The councillors were to decide which 'works of charity'

sunt posita fundamenta, volo inquit, ut compleatur opus illud usque ad plenam ipsius capelle consumacionem, scilicet iuxta eam formam et modum, secundum quod condixi et convencionem feci cum muratore. Et in eadem capella, cum perfecta fuerit, edificari debet altare et consecrari, in quo iugis fiat missarum celebracio ad laudem Dei et eius genitricis honorem, pro anime mee et filii mei ac progenitorum meorum suffragio salutary $[\ldots .$.$] . Deinde descendens memoratus fundator ad institutionem ministri et patrono-$ rum: Volo, inquit, ut iste presens hic Nicolaus Schreiberdorff de Brega primus sit predicti altaris altarista qui ad provisionem meam, quam ei dedi iam cepit ad sacros ordines promoveri, post illum vero deinceps, quociens idem altare vacaverit, domini consules civitatis Cracovie, qui pro tempore fuerint, presentare ad ipsum debent unum ex vicariis ecclesie beate Virginis predicte senioribus, qui ipsis consulibus magis idoneus videatur. Ipsis enim dominis consulibus do et confero ius patronatus ipsius altaris et presentandi ad ipsum, ut predictum est ab his perpetuis temporibus possidendum"; CONS. 428 , fol. 344 (1435); cf. Sławomira Pańków, “Michał Lang (de Czirla)," in PSB vol. 16, 481-482.

"Item zo hot her benumet bescheiden und gegeben IIIc ungaricales gulden zu einir stiftunge eynes ewigen altarum yn unser lieben frawen kirchen dor ouff man II messen dy woche sal lesen eyne vom Heiligen geistis dy ander von unser lieben frawen zum welchen altaris her itczunder gepuntiret hat Johannem unsir undirstatschreyber, noch welchis tode her den hern Rothmanne von Croke ouch eyn vorleyen eynes altaristen vorlegen und gegeben ffort sal sulch lehen an seyne frunde bekomen"; LT, fol. 105-107 (1484). cf. SCAB. 6, fol. 190 (1439), 213, 215 (1440); SCAB. 7 , fol. 7-8 (1447). 
to support for the salvation of Dorothy's soul. ${ }^{336}$ In some cases, the fact that the testator left money to the municipal council meant that the council had to first collect the money for the works of charity from debtors, as was the case with the will of Thob Johan, ${ }^{337}$ or liquidate valuables. ${ }^{338}$ For example, the tailor Jarosz testified that he possessed 34 silver spoons, three silver belts, four gold rings, two coral rosaries, two dagger scabbards decorated with silver ornaments, a silver belt, four silver mugs and 250 florins in gold in his chests. "He entrusted all of this to councillors to spend on works of charity, upon determining where the need was greatest, according to their will."339

In Krakow, as in other cities, the municipal council assumed oversight of the city's hospitals. ${ }^{340}$ This is visible in many wills in which donations were made to benefit the poor in general or to one of the hospitals within the Krakow agglomeration. In 1413, Elizabeth, widow of Nicholas Rozler, donated 20 grivna she was owed to the Hospital of the Holy Spirit. As the executors of her will, she appointed Nicholas Schultis and Matthias, an administrator (prowizor) responsible for the poor, "or any other councillor selected in his place."341 The councillor Wilhelm Willand made a bequest of 25 grivna to a hospital in

336 "Item allis ir oberig gelt und gut, alz IIc marg ire morgengobe, XXX marg bereytis geldis, alle ir teyl ires vetirlichen angevellis, und alle ire gerade, dy ir mit rechte geboren mag was doran oberig bleibit, obir das vorgeschrebene bescheidere gelt, das hat se den Ersamen weysen dem ganczen Rate, und den Ratmannen allin czu Cracovia bescheiden und bevolhen noch irem trewen und besten vornemen czuwenden wo das allir notdurftigiste wirt seyn, in dy werk der heilgen barmherczikeit, durch zelikeit willen irer zele"; cons. 427 , fol. 241 .

337 He ordered that goo florins from Koszyce and Bardejov he was entitled to should be reclaimed by his son and stepson, and given to the councillors, so that they could use it for works of charity to help the poor; LT, fol. 7-8 (1443).

338 Alderman Matthias Opoczko donated 21 silver spoons, a silver gold-plated cup (picarium alias kubeck), two silver women's belts, all his receivables, supellectilia, garlands (vittas), four carpets (tapeta), all his other household items and tools (apparatus) and a chalice (calix) made of three marks of silver to the St. Mary's Church; LT, fol. 108-109 (1473).

339 "Que omnia pro operibus misericordie commisit post mortem suam distribuenda et danda ex manibus dominorum consulum pro libitu et voluntate eorum ubi melius et divius videbitur expeditum"; LT, fol. 151-152 (1492).

340 Marek Słoń, "Fundacje szpitalne władz komunalnych jako centra kultu miejskiego," in Ecclesia et civitas, $361-373$.

341 "Elizabeth Niclos Rozlers witwe, durch Niclos Schultis ir doselbist czu vormunde nemende, hat der LV mrc dy ir Thomas Spiczschirch eyn fleyscher schuldig ist, der sie vorderunge Nicolaum Platener vormols mechtig gemacht hat XX mrc den Armen sichen in dem hospitali czum Heiligengeiste legenden und dreyssig mrc czur den Paulern czum gebeude des Clostirs noch irem tode bescheiden czu gebin. Alzo dasman dy XX mrc sal gebin Niclos Schultis und Mathie der Armen Sichen obgenanten Bitter, adir dy denne czu der czeyt denselbin Armen von den Ratleuten gesaczt werden und dy oberigen V mrc 
Krakow, asking the municipal council to distribute the money. ${ }^{342}$ Similarly, in his $145^{2}$ will, the village administrator Peter Filipowski donated ten grivna to a hospital in Krakow. The money was to be given to the municipal council, which, in turn, was to use it to benefit the poor and fund the maintenance of the hospital building. ${ }^{343}$ In 1487 , Hedwig Granoszowa explicitly designated the municipal council as guardians (vorweser) of the poor and the sick at the Hospital of the Holy Spirit, asking them to donate her house to the hospital. ${ }^{344}$ In 1435, Peter of Tenczyn, an altarist from Sącz, donated valuable items to the Krakow municipal council, in this way carrying out the will of a burgher from Sącz. Councillors, who are referred to in the document as 'guardians of the poor' (vorwesern der armen sichen) ${ }^{345}$ recorded that they had spent four grivna to buy fabrics for the poor, while the rest of the money was to be used to buy other necessary items for them. ${ }^{346}$

The municipal council did not only act as 'guardians' and 'patrons' of chapels, altars or prebends funded by testators. As part of the municipal authorities, councillors were often asked to act as executors of all the testamentary bequests in a will. For example, alderman Erhart Eigilwart (a Krakow burgher who originally hailed from Augsburg) named two councillors, George Szwarcz and Wilhelm Willand as the executors of his will. ${ }^{347}$ In his 1439 will, another alderman, John Briger, stated that after his death his widowed daughter and her two sons would be left unsupported, and asked that councillors, with the aid of God and the Virgin Mary, act as guardians and executors of his will, and

wil sie selbir von deme obgenanten Thoma offhebin und nemen dorobir behelt sie in dy herschafft dy weyle się lebit"; cons. 428 , fol. 46 . CONS. 428, fol. 369 (1436).

343 "Item executores ipsi vendere debent domum suam in platea sancti Johannis et pecuniam exinde pro edificiis Ecclesiarum subscriptarum convertere et distribuere scilicet pro pauperibus hospitalis in Cracovia et ipsorum necessitate $\mathrm{X}$ marg et ille debent dominus consulibus presentari qui eam in usum pauperum vel ipsorum edificacionem dispendere debebunt"; LT, fol. 28.

344 "Hedwigis Granoschowa mit gutter vornunft wesinde sitczende off den stule in der stobe yn yren hawse unbetwungen mit gutten freyen willen hat yre haws off der twergassen kegen bursa pauperorum czwuschen her Clethner und Casper Parchwicz gelegen mit allen den rechten als sy das bis do her gehat hat und mit 1 marg czins erdczins czinsinde alle jor den armen sichin in den Spital zum heiligen geisten den selben armen sichen offgegeben also das dy herren Rathmanne als vorwesir der selben mit den selben zu thuen noch yren besten vornemen ydoch wil sy frey wonne yn den selben hawse dy weile sy lebet"; LT, fol. 145 .

345 CONS. 428 , fol. 35 o.

346 "Item von dem gelde habe wir gegeben IIII marg czu czichen den armen kraken und das obirge ist komen czu andirr notdorft der armen"; ibidem.

CONS. 428 , fol. 305 (1431). 
administrators of his estate. ${ }^{348}$ Some testators, such as Barbara, daughter of Michael Unger, appointed two or three specific people as executors of her will (in most cases at least one was a member of the municipal council). However, Barbara also stated that councillors should carry out her will if the people she had appointed refused. ${ }^{349}$ Testators sometimes asked the municipal council to manage their estate because they feared it would be squandered. For example, in his 1459 will, goldsmith John Beme asked the municipal council to make an inventory of goods he kept in a chest and then seal it so that nothing went missing. ${ }^{350}$ Interestingly, it seems that it was around that time that the municipal council also began to compile inventories of late burghers' possessions.

Funding a chapel, altar or prebend, which was practically speaking an act of 'buying a place in a church,' was usually very expensive. It could even cost as much as one's entire estate. However, such generous bequests were seen as a gift for God, the urban community and, above all, the testator's family. This gift was not only meant to ensure testators' eternal life, but also glorify them among the living. Such a bequest was meant to render the testator 'immortal' and bring them benefits until the Final Judgment, which is why childless or heirless testators often renounced their right of patronage, asking municipal authorities to act as guardians for the chapels, altars and prebends they financed.

Indeed, instructions pertaining to the execution of the will and the need of guardianship are mostly connected with the 'patronage' over the will that the municipal council began to exercise in the late fourteenth century. In practice, this meant that two members of the municipal council visited the testator on his deathbed in order to officially draw up and authenticate the will. The

348 "Ich sterbe meyne hawsfraw, meyne tachtir Katherina mit iren czween sonen, so bite ich dy erben hern Ratmanne daz sy meyne vormunde und ausrichter seyn sullen umb gotis willen und unser liben frawen des testamentis und meyner guter farnde und unfarnde was do bleiben wirt"; sСАВ. 6, fol. 188 .

349 "Elegit in tutores huius testamenti Jacobum Glaser et Thomam Bastgert, si se submittere vellent et suscipere omnis nollent suscipere Quic dominos consules Cracoviensi denominavit et petivit propter deum ut ipsi susciperent tutelam et fidei commissiam et distribuerent bona sua ut super expressum est, cum omnia proprietate et facultate quam tutoriam et executiorem testamenti cum dicti Jacobum Glaser et Thomam Bastgert Eciam requisiti et petiviti suscipere noluerent nos enim Consules suscepimus et illud testamentum expediendis nos submisimus et submittimus commisionem testatricis prout pro concive nostra facere tenetur"; LT, fol. 149-150 (1491).

$35^{\circ}$ "Libin herren meyne gutter dy ich habe bete ich und begere das dy beseen werden und vorsegilt, das dy nicht vorrockit worden, das dy ouch in eynem kasten eyngeslossen und vorsegilt werden"; LT, fol. $5^{8}$. 
Krakow municipal council also began to keep the first Book of Wills. ${ }^{351}$ Both actions demonstrate the wider phenomenon of religion civique. As an embodiment of power, authority and permanence, the municipal council assumed many of the responsibilities that had been traditionally the domain of the Church (pursuant to canon law) or the municipal bench court (pursuant to Magdeburg Law).

\subsection{Beguinages}

The municipal council's patronage over beguinages is another aspect of religion civique. Beguinages were small informal groups of single (unmarried or widowed) women, who pledged to abide by a set of rules guiding their religious and community life. They were often established by means of testamentary foundation bequests, with the municipal council acting as their guardians and administrators. ${ }^{352}$ The provisions of a beguinage's rules required them to participate in commemorative services (prayers for the souls of donors), ${ }^{353}$ perform charity work (care for the poor and the sick), ${ }^{354}$ and undertake skilled crafts (in keeping with the Christian work ethic). ${ }^{355}$ Scholars link the popularity of beguinages in the Middle Ages to the growing number of unmarried, and thus often poor, women who had difficulty supporting themselves. ${ }^{356}$ The limited number of convents and their unwillingness to accept such women into their ranks led some impoverished commoners to establish their own religious communities or to join other such groups. It seems, however, that at least their founders were primarily inspired by their religious beliefs, their aspirations to dedicate themselves more fully to devotional activities, and a desire to live a life modelled on those of the saints (the vita apostolica).

The presence of beguinages in Polish lands dates back to the latter half of the thirteenth century, while in the fourteenth century, their numbers grew

351 Cf. Chapter 1, Section 6.

$35^{2}$ On the basis of available sources, it is very difficult to distinguish between third-order convents, Beguines and so-called 'soul houses' (Seelhäuser). In the sources they are referred to collectively as conventus or Haus, and their inhabitants as sorores devotae, moniales or mulieres (Seelhäuser); Jarosław Szymański, Ruchy heretyckie na Śląsku w XIII i XIV wieku (Katowice: Instytut Książki, 2007), 90-91; Jerzy Wyrozumski, "Beginki i begardzi w Polsce," Zeszyty Naukowe Uniwersytetu Jagiellońskiego. Prace Historyczne, 35 (1971), 7-22, 15.

353 Jarosław Szymański, Ruchy heretyckie, go.

354 Ibidem, 95; Jerzy Wyrozumski, Beginki i begardzi, 12.

355 Jerzy Wyrozumski, Beginki i begardzi, 12.

$35^{6}$ Ibidem, 15-16; Jarosław Szymański, Ruchy heretyckie, 79. 
substantially in many urban areas, ${ }^{357}$ especially in Silesia, but also in the Małopolska (Sandomierz, Krakow) and the Wielkopolska (Torun, Poznan) regions. ${ }^{358}$ While there are only a few mentions of beguinages in fourteenth-century sources from the Krakow agglomeration, we can assume that beguinages had been common in Krakow since at least the 135 os. ${ }^{359}$ The oldest sources confirming the presence of beguines in Krakow are two records in books of the bench court from 1336 and 1338 respectively, in which "Benka, a nun" (Benka monialis), is mentioned. ${ }^{360}$ In 1344, the "nun Pauline" (Paulina monialis) was mentioned in the bench court book as a second beguine. We also know of a transaction that took place between Pauline and Peter, the superior of the Franciscan monastery. "With the consent of the king and the convent" (de voluntate domini Regis et consensu Tocius Conuentus fratrum Minorum), Peter sold her, for 40 grivna, a plot of land located next to the house of Tichon Snelli and opposite the cemetery. Pauline instructed in her eternal will (perpetuum testamentum) that after her death the municipal council was to use and manage the land to ensure the salvation of Pauline and her soul. ${ }^{361}$ Since the transaction was carried out with the consent of the king and since, as in the case of the nun Benka, the plot was located next to the house of the councillor Tichon Snell, we can assume that this was the founding act of a beguinage, whose members were to pray for the salvation of their benefactors and guardians.

357 Jerzy Kłoczowski, Wspólnoty zakonne, 200-201.

$35^{8}$ Jerzy Wyrozumski, Beginki i begardzi, 14. The first mention of their presence in Wrocław dates back to 1285 . There is information about the existence of 61 such congregations in Wrocław in the years 1373-1508, and Halina Manikowska estimates the number of their members at about 15 o people; eadem, "Klasztor żeński w mieście średniowiecznym," Roczniki Dziejów Spotecznych i Gospodarczych 42 (2002), 45; cf. Jarosław Szymański, Ruchy heretyckie, 91-92.

359 " [...] the presence of the Beguines in Krakow in the latter half of the fourteenth century is confirmed by sources. They enjoyed special protection from the municipal council and occupied several houses near the Dominican and Franciscan churches, as well as the no longer existing All Saints" Church; Jerzy Wyrozumski, Beginki i begardzi, 14; cf. idem, Produkcja sukiennicza w zgromadzeniach religijnych Polski średniowiecznej, Zeszyty Naukowe UJ. Prace Historyczne, 12 (1963), 16-17.

36o The first one concerns Benka keeping the inheritance of her father and mother, which had been claimed by the Franciscans, the parson of the All Saints' Church and a man named Dirsko Mandroska. Perhaps this suggests that a will had been made for these people, but was later invalidated by one of Benka's parents. In the second entry, she sells part of the plot next to councillor Ticzon Snelli's house to him, under the condition that a channel for rainwater from both properties is installed; NKiRMK, no. 1188, 1241

NKiRMK, no. 1524 . 
In a bequest dated April 4, 1352, Elizabeth de Dornburg asked the municipal council to exercise patronage over the house she had inherited from her parents, in which lived a convent of sisters (Conventus Sororum). After Elizabeth's death, the members of the Krakow municipal council were to become the eternal guardians and plenipotentiaries of the sisters, who devoted their lives to God and praying for the salvation of their ancestors (devotarum deo serviencium temporibus perpetuis in remediumanimarumpredecessorumsuorum). ${ }^{362}$ A similar transaction took place in the same year when Claire, daughter of the magister Martin likewise asked the municipal council to exercise patronage over a house located at the Franciscan monastery. ${ }^{363}$ In 1354, there is mention of two nuns, Agnes and Hedwig, who donated a house in which there was a beguinage (Conventus pro Monialibus et Sororibus Beginis), located opposite the Dominican monastery, to councillor Peter Weinrich and his successors, provided he agreed to act as its guardian. The analysed sources demonstrate that in the mid-fourteenth century, the municipal council actively tried to assume guardianship over such houses, inhabited by "informal female associations." This may have been related, to some extent, to the persecution Beghards (lay religious male communities) were experiencing in Europe at that time, and the charges of heresy levelled at some Beguine congregations. ${ }^{364}$ It seems, however, that the councillors' desire to support these communities derived primarily from their interest in reaping the financial benefits, in accordance with the notion of the 'economy of salvation.' ${ }^{365}$

In the late fourteenth century, Dorothy Banarika, the widow of the stallholder Martin, made numerous pious bequests to Krakow's beguinages. In her three wills made between 1394 and 1395, she mentioned three convents, even providing the names of sisters who resided in two of them (Wartinberginne and Langekethe). The first beguinage was said to be located opposite the Dominican monastery. It was probably the same house over which Peter Weinrich earlier exercised his patronage. The second beguinage was probably that founded by Elizabeth de Dornburg or Claire, the daughter of the magister

$362 \quad$ NKiRMK, no. 1643 .

363 Józef Szujski writes about it in the introduction to the NKiRMK, LV.

364 Jarosław Szymański, Ruchy heretyckie, 84.

365 Ibidem, 94. Piotr Oliński also writes about such phenomena occurring in Prussia since the late thirteenth century: "They arose out of the private initiative of the burghers, in agreement with municipal councils and often later were placed under their jurisdiction. [...] Foundations for houses for women, widows and the poor were often made by widows and bound to the memoria of the owner of the donated property. [...] In terms of religion, they were placed under the care of monks from the mendicant orders or the local parish priest"; idem, Fundacje mieszczańskie, 61-62. 
Martin, and affiliated with the Franciscans. The third beguinage was said to be located at the Bishop's Palace, i.e. also near the Franciscan monastery. ${ }^{366}$ The beguinages mentioned in all three cases were located between St. Florian Street and the Dominican Church of the Holy Trinity. Such a concentration of houses inhabited by beguines was rather typical. For example, we know that in Świdnica, Legnica and Kłodzko, beguinages were all located in streets of the same name, i.e. Nuns Street (Nonnengasse). In Wrocław, all beguinages were located near the Dominican Monastery (St. Adalbert's Church) and the monastery of The Knights of the Cross with the Red Star (St. Matthias's Church). ${ }^{367}$ These locations also demonstrate that beguinages were affiliated with specific orders, which provided Beguines with religious guidance and perhaps even inspired them to establish new beguinages. ${ }^{368}$ For example, Dorothy Banarika also made a bequest to a girl (puelle) named Barbara, who worked as a servant for the Poor Clares at St. Andrew's Church. ${ }^{369}$ Both Dorothy Banarika and Barbara were probably Beguines, because we know that in 1306 the Poor Clares in Wrocław were given permission by the Pope to keep one or two female companions. ${ }^{370}$

The above-mentioned sources allow us to determine the material status of some Krakow Beguines. It seems that the Beguines mentioned in municipal books were relatively affluent. We know that Pauline could afford to buy a plot of land for 40 grivna and that Elizabeth de Dornburg donated a house she had inherited from her parents. We also know that Dorothy Banarika was married to the alderman and stallholder Martin and that Claire was the daughter of the magister Martin. These women thus belonged to relatively rich burgher families. If Pauline, Elizabeth de Dornburg, Dorothy Banarika, and Claire were also the founders of these convents (at least some of them), they would thus exemplify the religious passion and devotion characteristic of some medieval burgher women. We should also remember that most of these women were

366 "Item ad conventum monialium, ubi moratur Wartinberginne ex opposito Fratrum Predicatorum IIII mrc, item ad conventum monialium, ubi moratur Langekethe II mrc, item ad conventum penes curiam domini episcopi II mrc."; SCAB., no. 1893, 1866, 2092.

367 Jarosław Szymański, Ruchy heretyckie, 92.

368 Halina Manikowska considers this phenomenon in terms of the 'spiritual' safeguarding of the city: "The nuns, committed to purity and living in the holiness of virginity, founded a holy monastery city. [...] This accumulated 'power of virginity' reflected the power of the city, which was able to maintain and sustain them."; Halina Manikowska, Klasztor żeński, $24-25$.

369 In the second version of the will, the same amount of two grivna was allocated to the father of this girl; SCAB., no. 1893 .

370 Cited in Szymański, Ruchy heretyckie, 94. 
(and decided to remain) widows. Testamentary bequests confirm that many burghers preferred for their wives to remain widows, and bestowed on them numerous privileges. They were seen as devoted guardians of their minor children, but also as providing the best means for cultivating the memory (memoria) of their late husband, honouring him and praying for his soul. Beguinages thus offered widows an attractive arrangement: they could live together as a community with fellow burgher women in a shared home.

A feeling of connectedness with the wider, abstract community of all Christians, an important element of Church teaching, was slowly forming in the secular community, as well. ${ }^{371}$ Since there was no actual social community embodying the Christian community as a whole, one had to imagine one, which required a religious awareness and intellectual horizons that exceeded the boundaries of one's own municipality. Apart from proselytism, the foundations for the construction of such a community were provided by travel: the itinerant craftsmen's journeys, merchants' travels, military expeditions (especially against the Saracens) and, perhaps above all, pilgrimages, which became increasingly popular in the Middle Ages.

Like other aspects of urban religiosity, the pilgrimage had existed for generations. However, as a result of the intensive changes taking place in urban culture in the fourteenth and fifteenth centuries, pilgrimages during this period acquired a new significance and previously unmatched level of popularity. ${ }^{372}$ Pope Boniface VIII's plenary indulgence of 1300 (which actually dated from Christmas 1299), granted to pilgrims travelling to the great Jubilee in Rome, was one of the most important factors in the rise of pilgrimages in medieval Europe. During the analysed period, the official dates of the Jubilees which

371 One example of this phenomenon in the subject literature is the negligible participation of the inhabitants of the Polish lands between the eleventh and thirteenth centuries in the crusade movement, while another is the absence of any traces of anti-Jewish incidents until the late 13th century.; cf. Jerzy Dowiat, Normy postępowania i wzory osobowe, in Kultura polski średniowiecznej, 319-321.

372 "The history of the first two centuries of jubilees illustrates well their role in the development of late-medieval piety and the rapidly growing importance of indulgences in religious life. This is especially visible during the pontificate of Boniface IX (1389-1404), who started selling various types of indulgences on a massive scale, and jubilees became the main incentive for pilgrims to travel to sanctuaries endowed with the privilege of granting them"; Halina Manikowska, Jerozolima - Rzym - Compostela, 6-8. 
attracted pilgrims to Rome were the years $1350,1390,1400,1423,{ }^{373} 1450,1475$ and 1500. ${ }^{374}$ Undoubtedly, however, as evidenced by the analysed sources, the faithful made pilgrimages to visit holy places in other years, as well.

The popularity of pilgrimages to holy places in Europe seems to have been less dependent on wealth or social position than other more elite forms of piety. ${ }^{375}$ A larger role must have been played by personal motivations, religious zeal and the wish to be involved with other highly devout believers, who placed piety above personal gain, comfort and a sense of security. In terms of religious motivations, the desire to visit the tombs of saints, see holy relics and gain plenary indulgences all played an important role. Before setting out on a pilgrimage, Nicholas of Cieszyn transferred his entire property to his wife, stating that he was going on this journey in order to attain eternal life (profecturus ad limina beatorum intendens saluti sue $) .376$

Indulgences could also be granted to those in whose name a sacred pilgrimage was being made. The belief spread that indulgences could 'erase' punishment for sins, or even the sins themselves, and thus ensure salvation. Those testators who, for various reasons, were unable to go on a pilgrimage themselves and thereby gain indulgences, sometimes asked their family members to do so on their behalf. The widow Nela Folmosin left her house and cloth stall to her son, asking him, among others, to order a pilgrimage to Rome for her sake after her death. ${ }^{377}$ In his will of 1400, Andrew Melczer ordered two pilgrimages (one to Rome and one to Aachen). ${ }^{378}$ John Czenmark, among other dispositions, made a bequest of 40 florins to pay "for a pilgrimage to Rome" (of eyne Romfard). It was to be made by an appointed person in the name of Czenmark's salvation. ${ }^{379}$ A similar motivation led Bartholomeus, a wealthy tanner (and, as evidenced by his will, a steel and lead merchant), to instruct the executors of his will to send a religious man, "or any other good man," to Rome, and

"The next jubilee, which, according to Urban VI's decision, was due to take place in 1423 , was probably never officially announced, but still attracted crowds of pilgrims to Rome, although numerous testimonies document their presence rather in 1424"; ibidem, 7 . Ibidem.

This is clearly expressed in Geoffrey Chaucer's Canterbury Tales; cf. "The pilgrimage itself could have cost very little and was accessible to the truly poor"; Halina Manikowska, Jerozolima - Rzym - Compostela, 369 .

NKiRMK, no. 1189 (1336).

"Domina Nela Folmosin condam Stanislai relicta, Hannus Monacho pro tutore recepto, domum suam, cimiterio sancte Anne contiguam, cum scampno panum, Stenoni filio suo post mortem ipsius resignavit taliter, quod idem Steno viam Romanam unam et unum stamen griseum cum IIII mrc. debiti solucione debet ordinare"; sCAB., no. 884 (1373).

"[...] ich bevele asczurichten eyn fusgengir czu eynir Romfart und eyn czu eynir ochfart"; CONS. 427 , fol. 157 .

"Item of eyne Romfard XL rote golden"; CONS. 428, fol. 354 (1436). 
cover the costs associated with the pilgrimage. ${ }^{380}$ Another entry in the book of the bench court appears to be evidence of an attempt to carry out a testator's instructions. Hano Hesse, a burgher from Krakow, swore under the penalty of ten grivna that a man called Cuncze Rudila would present proof of his journey to Rome and Aachen by the feast day of John the Baptist. ${ }^{381}$ Cuncze Rudila was to go on these pilgrimages "for his brother Michael Czobot" (di Romfart und ochfart, di Cuncze vor synne brudir tun sal, eczwen Nichil Czobot). ${ }^{382}$ In another entry, we see someone vouching for a pilgrim about to set out on his journey (possibly not entirely willingly); here Peter Peszko agrees to go to Rome and bring back a letter as a proof of his journey (quod Romam debeat transire et literas reportare). ${ }^{383}$ A pilgrimage was more than just an act of penance, a quest for indulgence, or a journey to seek aid from a patron saint (or thank them for help one had already received). In view of the risks and costs involved, a pilgrimage was also a means of redeeming oneself, even after having committing a grave crime. ${ }^{384}$ For example, murderers or other serious criminals were given a chance to redeem themselves and thus regain the status of burgher. Jörg Steinkeller, a convicted coin forger, or the people who took part in the Wrocław rebellion of 1418, were given such a chance as well. 385 Perhaps the aforementioned Peter Peszko was also a convicted criminal who redeemed himself by going on a pilgrimage. Such a situation is described in a letter written by John, a parish priest from Bystrzyca (de Wystricz), that was attached to the Kazimierz municipal books. John writes that Bartholomeus, a butcher and burgher of Bystrzyca, killed Nicholas, a stonemason. Bartholomeus was convicted and sentenced to death. However, as a result of numerous pleas and guarantees given by priests, pious wives and widows, the murderer was given a chance to redeem himself by going on a pilgrimage to the tombs of Saint Peter and Saint

380 "Item si decesserit ipse tunc executores huius testamenti expedire debet in curiam Romanam unum sacerdotem vel alium probium virum cum expensis competentibus"; LT, fol. 35 (1455).

381 "Das Hano Hesse ist burge wordin vor Concze Rudil umben di Romfart und ochfart, di Cuncze vor synne brudir tun sal, eczwen Nichil Czobot, ab der obgen[annten] Cuncze Rudil nicht beweisunge czwischin synte Iohannis tage baptiste brengit von Rome und oche so sal Hano Hesse X marcas grossorum vor di hirren legin, brengit her abir beweisunge, so sollin dem vorgenanten Cunczen volgin di X marcas grossorum"; CONS. 427, fol. 11 (1393).

382 Name of Nicholas Czobot was also found in the Book of the Dead of the Brotherhood of the Blessed Virgin Mary.; cf. Józef Mitkowski, Księga zmartych, 83.

383 CONS. 427 , fol. 46 (1394).

384 cf. Hanna Zaremska, "Pielgrzymka jako kara za zabójstwo: Europa Środkowa XIII-XV w.," in Peregrinationes. Pielgrzymki w kulturze dawnej Europy, ed. Halina Manikowska, Hanna Zaremska (Warszawa: Instytut Historii Polskiej Akademii Nauk, 1995), 147-151.

385 Halina Manikowska, Jerozolima - Rzym - Compostela, 237. 
Paul in Rome. ${ }^{386}$ John Tuesgerne, a convicted murderer, was also pardoned in this way - he was ordered to make a pilgrimage to Rome, join a brotherhood in Wielun and pay for a hundred Masses for the soul of the man he had killed. 387

Fourteenth-century and fifteenth-century sources mostly document the fact that Krakovian burghers went on pilgrimages to Rome. However, some sources demonstrate that they also visited two other very important sanctuaries in the Christian world: the holy city of Jerusalem, to visit the tomb of Christ (ad limina sepulcri dominici),, 388 and to the tomb of the Apostle Saint James the Greater (ad sanctum Jacobum) in Compostela. ${ }^{389}$ Apart from these important peregrinationes maiores, pilgrims also travelled to Aachen to see the famous holy relics (often combining this trip with a pilgrimage to Rome) and to Wilsnack in Brandenburg, which became a pilgrimage destination in 1384, when three bleeding hosts (via ad sanguinem Christi) ${ }^{390}$ were found in the ruins of a local church.

Krakow municipal books from the fourteenth and fifteenth centuries show that during that period at least 68 burghers planned to go on a pilgrimage far from home. The number of such testators is undoubtedly much higher, however, as the reasons for drafting a will were not always stated. Sometimes the testamentary document was not a typical will, but merely a form of a mutual donation, a bequest of property to be made in the event of one's death, or a letter in which guardians for the wife and children were named. Such instructions or bequests were often recorded one after another and were indeed quite similar in terms of form and structure. It can thus be assumed that many other Krakovian burghers also wished to go on a pilgrimage, most probably to Rome, even though they did not explicitly state this in the analysed sources. ${ }^{391}$

386 Ksiegi radzieckie kazimierskie 1369-1381 i 1385-1402. Acta consularia Casimiriensia 1369-1381 et 1385-1402, ed. Adam Chmiel, Krakow 1932 (Wydawnictwo Aktów Dawnych miasta Krakowa, 2), 140.

387 "Hannus tuesgerne promisit pergere Romam et fraternitatem invenire et lucrari in Welun causa homicidii perpetrati et hoc debet facere post festum S. Ih. Bpt. Indilate et debet acquirere C missas"; CONS. 427, fol. 151 (1400).

388 Nicholas Rutenus was planning a pilgrimage to Jerusalem; NKiRMK, no. 1036 (1330).

389 Elian, a burgher from Kazimierz, was travelling there; Księgi radzieckie kazimierskie, 447 (1398).

390 Stanisław Bylina, Religijność późnego średniowiecza, 55 .

391 Such a situation can be observed, for example, in the bequests of Chunad de Tost and Chunad Wolf. They are immediately adjacent to records from the same day concerning Margaret, Nicholas Wronche's mother-in-law, and Catherine, widow of Hankon from Gliwice, who made bequests in the event they did not return from a pilgrimage to Rome. Although there is no mention of the pilgrimage in the records on either Chunad, the 


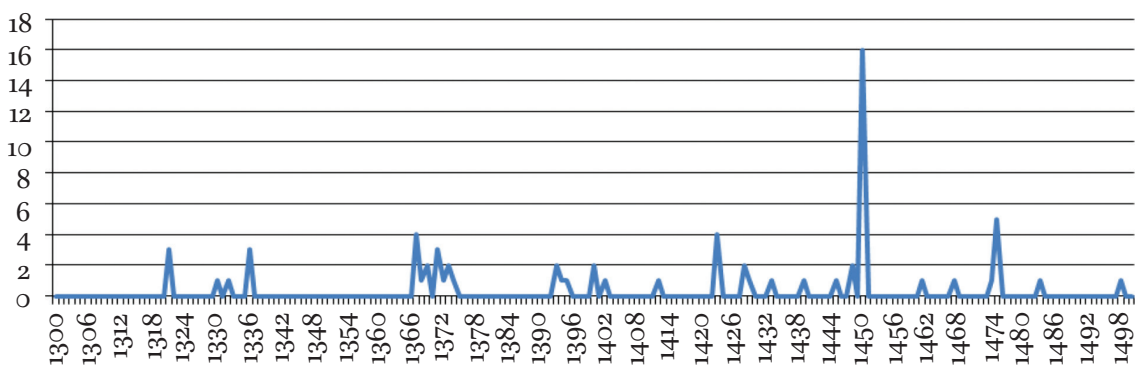

GRAPH 16 The number of testators who made wills before going on a pilgrimage

The data contained in the chart below (Graph 16) illustrates the documented number of Krakovian burghers participating in the pilgrimage movement throughout the Western World. Unfortunately, it is not representative of the entire population, but only of the city's elite. However, some less-wealthy people are also included, such as Irmtruda (who owned a house in front of the Szewska Gate), ${ }^{392}$ Paul Korcze, a tanner, ${ }^{393}$ or Margaret, mother-in-law of Nicholas Wronche, who left behind two children and only seven grivna. ${ }^{394}$

The chart shows that the number of wills made before going on a pilgrimage correlates closely with the dates of the great Roman Jubilees. Indeed, Krakovian burghers knew that the Jubilee years were special years, during which thousands of pilgrims would set out for Rome in pursuit of plenary indulgences, and they too wished to participate in this special event. The Jubilees in the years 1423, 1475 and above all 145 (most of the surviving wills from the analysed period were made in 1450) are all clearly visible in the chart. The Jubilee of 1500 is not included in it due to the loss of bench court books from the end of fifteenth century. However, a number of wills that had probably been made in connection with this Jubilee were recorded in Krakow's municipal books in the years that followed.

Going on a pilgrimage was an expression of deep and profound piety. It was an exceptional and glorious act which required significant financial resources and great sacrifice. A pilgrim wished to be rewarded after death, but could also count on some rewards while still alive. Indeed, in a society whose value system

numerous pious bequests included there and the expression inquantum moriretur in via in the record concerning Chunad Wolf are indicative of such a motivation; cf. SCAB., no. 218-221.

392 NKiRMK, no. 1088 (1332).

393 SCAB., no. 548 (1371).

394 SСAB., no. $218(1367)$. 
was based on the preaching of the Church, going on a pilgrimage or financing an altar or a chapel was a source of pride and prestige. We can assume that making pilgrimages, like being a member of the elite Brotherhood of the Blessed Virgin Mary at St. Mary's Church, allowed one to achieve and maintain a strong position within the social hierarchy of the urban municipality, especially in patrician circles. As the historian Halina Manikowska put it: "Apart from collecting indulgences, especially private indulgences, a long pilgrimage, especially to Jerusalem to see the Holy Sepulcher, was an important element of the urban lifestyle and one of the determinants of social prestige."395 This is exemplified by the wealthy councillor Nicholas Rutenus, who decided to go on a dangerous and expensive pilgrimage to Jerusalem in 1330 (and most probably never returned to Krakow). ${ }^{396}$

When we study religiosity, we are often forced to focus only on external manifestations of people's inner religious life, limiting ourselves to the study of social relations and declarations. We rarely gain insight into what lies 'inside' a person. Yet, religiosity is not only conceived of in terms of mysticism and internalised articles of faith; it should be seen, first and foremost, as a communal and public phenomenon, involving outward manifestations - symbols and concrete actions - of one's religious belief. Such external and analysable manifestations of faith allow us to observe the existence of a strong connection between the manner in which society is organized and its religious practices. Every society has its own unique religious practices, which help unite it, alleviate its fears, and provide its members with a means of coming into contact with the sacred. On the one hand, in the Middle Ages, the ritualization of life within the family, guild, parish, and even the city itself, helped unify social groups. On the other hand, as a result, society's internal hierarchy became more fixed. In the context of the family, this meant honouring the memory

\footnotetext{
395 Halina Manikowska, Jerozolima - Rzym-Compostela, 16.

396 "[...] dominus Nycolaus Rutenus ad limina sepulcri dominici se aptando"; NKiRMK, no. 1036. Based on the notes of the Wrocław burgher Peter Rindfleisch from his pilgrimage to the Holy Sepulcher in 1496 , it can be calculated that he spent the significant amount of 222 florins on the entire journey, including all the necessary purchases made on the way. It can be assumed that the journey of Nicholas Rutenus, made 166 years earlier, must have involved an equally significant, if not greater, financial investment; cf. Halina Manikowska, Jerozolima - Rzym - Compostela, 78-79.
} 
of one's ancestors and emphasizing the dominant role of the father. In the context of the city of Krakow (for example during the annual Corpus Christi procession), this involved emphasizing the dominant role of the municipal council and acknowledging the place occupied in the municipal hierarchy by every corporation, guild and brotherhood. ${ }^{397}$

The examples discussed in this chapter certainly do not represent all the spheres of life in which Krakovian burghers participated, be they public or religious. ${ }^{398}$ They also do not exhaust the list of ways in which Krakow's inhabitants tried to secure their salvation.

They represent, however, the variety of religious practices in which wills played an important role. Although devotional practices and pious records existed alongside and in the absence of wills, it was the institution of the will that provided them with a special power and protection, and it seems that it contributed significantly to their dissemination among the townspeople. The first chapter explains the genesis of the medieval will, created primarily as a tool for the efficient transfer of material goods to the institution of the church. Then, however, after its dissemination in the urban environment, the testamentary practice was adapted to the urban needs. Especially the needs of the upper classes of the bourgeoisie. Wills made the posthumous future of wealthy burghers independent of the good will of their relatives. They allowed testators to take care of their eternal life by themselves i.e. by transforming their economic capital accumulated during lifetime into 'eschatological capital.' For this purpose salvation specialists were used, such as mendicant congregations or urban poor. Efforts were also made to maintain the memory and provide prayers for the soul of the deceased in parish churches, among religious brotherhoods or by trusted clergy. Finally, by the power of testamentary bequest, testators could plan and supervise their own memorial activities for which spouses, children or distant relatives were responsible.

397 "For fraternities, as for other corporations, the celebrations, apart from proving their position in the social structure of the municipality, were an opportunity for the members of their community to meet people from outside the organization. Their intention to demonstrate their power to others and emphasize their wealth and rank explains to a large extent why the members were obliged to participate in the celebrations. Competition for a place in the Corpus Christi procession, which is testified to by sources from the early sixteenth century concerning guilds, and from the end of the century in terms of fraternities, are proof that these corporations understood well that this opportunity to present themselves to the city should not be ignored"; Hanna Zaremska, Bractwa, 153 .

398 E.g. the existence of communities established on the basis of language, as manifested, for example, in affiliating in 'Polish fraternities' or in bequests to pay for Polish and German preachers. 
Wills, sometimes written many years before death, due to their revocability until the end of their lives, gave wealthy testators power over the living, whom they could appreciate in their records or condemn and practically disinherit. Similarly, generous contributions made to religious institutions allowed them to enjoy their favor even during the testator's lifetime. While the prestige and glory associated with costly religious foundations served as the accumulation of symbolic capital by members of city's elite.

In the medieval city, the religious and the social intertwined. Indeed, as Johan Huizinga observes: "Life was permeated by religion to the degree that the distance between the earthly and the spiritual was in danger of being obliterated at any moment. While on the one hand all of ordinary life was raised to the sphere of the divine, on the other, the divine was bound to the mundane in an indissoluble mixture with daily life." ${ }^{399}$ 'Internal' religious needs went hand-in-hand with the desire for self-presentation; the personal intertwined with the social. As Manikowska observes: "In the late Middle Ages, we are dealing with a complicated and dynamic arrangement: individualism-actions benefiting the community; privacy — actions benefiting the public sphere."400 The analysed wills from the fourteenth and fifteenth centuries demonstrate how Krakovian burghers patronised both long-established and newly-founded churches and monastic communities, and how their preferences changed over time. ${ }^{401}$ But they also show how burghers both perceived and exhibited newly emergent types of religious bond. Despite reasonable doubts as to whether wills and testamentarybequestsaccurately represent theentire urbansociety, ${ }^{402}$ my analysis demonstrates that we can observe here two models of religiosity: (i) communal religiosity that was characteristic of the majority of urban society, and (ii) private worship that was practiced by pious individuals who wished to acquire a deeper understanding of their faith. The latter was not a mass phenomenon and it was largely tied to the rise of literacy. Such social and religious differences and the supposed opposition between the elite and mass models of religiosity do not, however, undermine the fundamental unity of religious beliefs 403 in late medieval Krakow: "Different cultural spheres coexisted in one and the same consciousness and they must have coexisted even

\footnotetext{
399 Johan Huizinga, The Autumn of the Middle Ages, 178.

400 Hanna Manikowska, Religijność miejska, 26.

401 This was one of the main subject areas analysed by Elżbieta Piwowarczyk in her work Legaty testamentowe ad pias causas wXV-wiecznym Krakowie.

402 Martin Nodl, Średniowieczny testament, 149-160.

403 Aleksandra Witkowska, Kulty patnicze, 218.
} 
in the educated minds of theologians, scholastics, university professors and church officials. Although these people were both educated and dogmatic, mythical, poetical and folklore images and thought patterns were nevertheless buried deep within their psyche."404

404 Aron J. Gurevich, "Kultura elitarna i kultura ludowa w średniowiecznej Europie," in Biedni i bogaci. Studia z dziejów spoteczeństwa i kultury ofiarowane Bronisławowi Geremkowi w sześćdziesiąta rocznicę urodzin (Warszawa: Wydawn. Nauk. PWN, 1992), 211. 